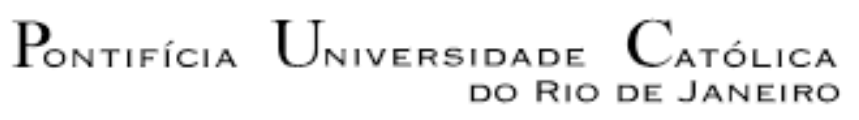

Bruno Ferrari

\title{
Múltiplos avessos: \\ Configurações do épico de referência clássica na literatura \\ contemporânea
}

\section{Tese de Doutorado}

Tese apresentada ao programa de Pós-graduação em Literatura, Cultura e Contemporaneidade do Departamento de Letras da PUC-Rio como requisito parcial para obtenção do grau de Doutor em Literatura Cultura e Contemporaneidade.

Orientadora: Prof ${ }^{a}$ Eliana Lucia Madureira Yunes Garcia 
Múltiplos Avessos: configurações do épico de referência clássica na literatura contemporânea

Defesa de Tese apresentada como requisito parcial para obtenção do grau de Doutor pelo Programa de Pós-Graduação em Literatura,

Cultura

Contemporaneidade do Departamento de Letras do Centro de Teologia e Ciências Humanas da PUC-Rio. Aprovada pela Comissão Examinadora abaixo assinada.

Profa. Eliana Lucia Madureira Yunes

Orientadora Departamento de Letras - PUC-Rio

Profa. Miriam Sutter Medeiros Departamento de Letras - PUC-Rio

Prof. Alexandre Montaury Baptista Coutinho Departamento de Letras - PUC-Rio

Profa. Maria Elizabeth Chaves de Mello UFF

Profa. Carlinda Fragale Pate Nunez UERJ

Profa. Monah Winograd Coordenadora Setorial do Centro de Teologia e Ciências Humanas - PUC-Rio

Rio de Janeiro, 19 de abril de 2017. 
Todos os direitos reservados. É proibida a reprodução total ou parcial do trabalho sem autorização da Universidade, do autor e da orientadora.

\section{Bruno Ferrari}

Graduou-se em Letras - Inglês/Literaturas pela UERJ em 2003. É mestre em Literaturas de Língua Inglesa pela mesma universidade (2006). Atua como Professor I de Língua Inglesa na Secretaria Municipal de Ensino do Rio de Janeiro (SME-RJ).

Ficha catalográfica

Ferrari, Bruno

Múltiplos avessos: configurações do épico de referência clássica na literatura contemporânea / Bruno Ferrari ; orientadora: Eliana Lucia Madureira Yunes Garcia. $-2017$.

138 f. : il. color. ; $30 \mathrm{~cm}$

Tese (doutorado)-Pontifícia Universidade Católica do Rio de Janeiro, Departamento de Letras, 2017.

Inclui bibliografia

1. Letras - Teses. 2. Gênero épico. 3. Contemporaneidade. 4. Paródia. 5. Modalização. I. Garcia, Eliana Lucia Madureira Yunes. II. Pontifícia Universidade Católica do Rio de Janeiro. Departamento de Letras. III. Título. 
Para Leila Harris, com a mais profunda admiração. 


\section{Agradecimentos}

À Prof ${ }^{a}$ Eliana Yunes, pela orientação, acolhida e confiança. Foram quatro anos de muito aprendizado.

À CAPES e à PUC-Rio pelos auxílios concedidos, sem os quais este trabalho não seria realizado.

Às Professoras Miriam Sutter Medeiros e Maria Elizabeth Chaves de Mello, pelas sugestões no Exame de Qualificação, que certamente fizeram a diferença.

Às Professoras Leila Harris e Carlinda Nuñez, por insistirem que era possível.

Às colegas Fabiana Pinho, Maria da Glória Almeida, Karine Aragão, Laura Assis, Carmélia Aragão e Janete Oliveira, pelo convívio agradável e pela ajuda em diversos momentos.

À minha mãe, Maria José, e à minha tia, Elvira, que tanto lutaram para que eu chegasse até aqui. Muito obrigado pelas orações, pela casa silenciosa e pela comida que afaga.

À Nana e ao João, por cuidarem da minha vida prática quando eu só podia dar atenção à acadêmica.

Às amigas Fabiana Júlio, Luciana Trindade e Mônica Linhares, por tornarem minha vida mais leve e por me fazerem enxergar melhor.

Às amigas Elena Brito e Jacira Corrêa, por me nutrirem com sua fé. Ao Sr. José de Alhandra, pela ajuda perene e pela segurança transmitida.

Às amigas Helaine e Heloísa Albuquerque, que tanto me ajudaram no início dessa jornada. A vocês, minha eterna gratidão!

Aos queridos Valmir Miranda, Renata Gomes, Wagner Costa, Caroline Reis e Barbara Lima, pelo apoio fundamental e pelo encorajamento na hora certa.

À querida Claudia Valentim, que empreendeu uma verdadeira odisseia para encontrar um livro importante para este trabalho. Obrigado por sua dedicação e amizade!

Aos queridos amigos da Escola Municipal Ubaldina Dias Jacaré, que tanto me ensinam diariamente, pelo apoio e pela torcida. Agradeço especialmente à Rose Finotti, Marcia Alves e Marília Faraco, pela compreensão e colaboração.

Ao Henrique Torres e ao Cláudio Gouveia, cujo trabalho tornou as viagens para a PUC-Rio muito mais curtas e agradáveis. 


\section{Resumo}

Ferrari, Bruno; Garcia, Eliana Lucia Madureira Yunes. Múltiplos Avessos: configurações do épico de referência clássica na literatura contemporânea. Rio de Janeiro, 2017. 138 p. Tese de Doutorado Departamento de Letras, Pontifícia Universidade Católica do Rio de Janeiro.

O objetivo principal deste trabalho é investigar sobre a permanência do gênero épico na contemporaneidade, a partir da leitura e análise das seguintes obras: Uma viagem à Índia, de Gonçalo Tavares, Viva o povo brasileiro, de João Ubaldo Ribeiro, A odisseia de Penélope, de Margaret Atwood e A odisseia de Homero (segundo João Vítor), de Gustavo Piqueira. O trabalho parte da premissa de que, assim como todo paradigma consagrado, na contemporaneidade, o épico é retomado e modalizado em diferentes gêneros formando novas configurações. Assim, focaliza o relacionamento que as obras do corpus estabelecem com as matrizes clássicas e seus procedimentos estilísticos, temas e motivos. Ao utilizarem o gênero épico como paradigma, todos os escritores estabelecem um relacionamento intertextual explícito e ambíguo com as matrizes épicas clássicas. A partir da referência a elas, eles promovem sua desconstrução e subversão e evidenciam seus vieses, ora questionando, ora reafirmando sua viabilidade e importância nos dias de hoje.

\section{Palavras-chave}

Gênero épico; contemporaneidade; paródia; modalização; 


\section{Abstract}

Ferrari, Bruno; Garcia, Eliana Lucia Madureira Yunes (Advisor). Multiple subvervions: classical-referenced epic configurations in contemporary literature. Rio de Janeiro, 2017. 138 p. Tese de Doutorado - Departamento de Letras, Pontifícia Universidade Católica do Rio de Janeiro.

The main aim of this work is to investigate about the permanence of the epic genre in contemporaneity by analyzing the following works: Gonçalo Tavares's Uma viagem à Índia, João Ubaldo Ribeiro's Viva o povo brasileiro, Margaret Atwood's A odisseia de Penélope, e Gustavo Piqueira's A odisseia de Homero (segundo João Vítor). This thesis departs from the point that the epic genre, like any other established paradigm, is and modalized in diferente genres, forming new configurations. Therefore, it focuses on the relationship that the works in the corpus entail with the classical matrix and its stylistic procedures, themes and motifs. All the writers studied establish an ambiguous and explicit intertextual relationship with the classical epics. Departing from the reference to them, they promote their deconstruction and subversion, evidencing their biases, both questioning and reinforcing their viability and importance nowadays.

\section{Keywords}

Epic genre; contemporaneity; parody; modalization; 


\section{Sumário}

1.Introdução

2. O clássico e o épico: sensores do tempo 17

2.1. O clássico, um conceito polissêmico e controverso 17

2.2. Gênero épico e epopeia: trajetória, caracterização e teorização 27

2.2.1. As matrizes épicas clássicas 27

2.2.2 O épico, do surgimento do romance à contemporaneidade 33

3. O épico à deriva: Uma viagem à Índia, de Gonçalo Tavares 42

3.1. Os Lusíadas: o hipotexto principal 45

3.2. A parodização do hipotexto em Uma viagem à Índia 49

4. Viva o povo brasileiro: o épico reverso 62

4.1. Épico e mito de fundação em Viva o povo brasileiro 64

4.2. A parodização dos procedimentos estilísticos 69

5. A Odisseia de Penélope : o épico em negativo 82

5.1. Pressupostos feministas, escritura e cânone 83

5.2. Releitura do mito e subversão paródica da epopeia 85

6. A Odisseia de Homero (segundo João Vítor): o épico infanto-juvenil 101

6.1. Literatura Infantil e adaptação 105

6.2 Adaptação e adaptação para jovens leitores 107

6.3. A modalização épica na obra de Piqueira 111

7. Conclusão 121

8. Referências bibliográficas 127

9. Anexos 137 
"A obra épica não é uma forma fixa; ela deve ser constantemente desenvolvida em obstinada oposição à tradição e seus representantes." 


\section{Introdução}

A ideia de morte do gênero épico a partir do surgimento do romance moderno, no século XVIII, adquiriu status simultâneo de verdade e senso-comum nos mais diversos meios. No entanto, na contemporaneidade, somos confrontados com inúmeras manifestações, as quais a crítica associa à expressão épica do discurso: de poemas a romances, de filmes a séries de TV, de obras infantis a jogos eletrônicos. O gênero, de fato, parece ainda estar sendo produzido em larga escala na atualidade, apresentando grande apelo junto ao público. Conforme observa J.A. Cuddon:

Nos últimos cem anos ou mais, o romance, o cinema e, em menor extensão, o teatro têm sido os meios mais favorecidos por narrativas em uma escala épica. Em retrospecto, parece um tanto lógico que, conforme o romance se desenvolvia, o romancista o considerasse um veículo adequado para o tratamento grandioso do destino nacional e individual. De fato, há um número impressionante de romances que poderiam muito bem ser descritos como épicos em seu escopo e magnitude (CUDDON, 1999, p.272, nossa tradução ${ }^{1}$ ).

Tais popularidade e retorno do épico remetem-nos também à questão do ressurgimento do clássico em meio à crise de representação e de autoridade que vivenciamos na pós-modernidade. O épico clássico se presta a diversos usos na contemporaneidade. De acordo com Paul Innes:

Elementos épicos informam desenvolvimentos contemporâneos em gêneros pós-modernos de todos os tipos. Isso pode indicar que a epopeia em si e sobre si não é mais possível ${ }^{2}$, mas a sobrevivência de alguns elementos chave da épica oral, nos séculos XX e XXI, demonstra que qualquer tentativa de escrever o epitáfio do gênero é prematura. (INNES, 2013, p.159, tradução nossa).

De fato, ao longo de sua história, o épico tem demonstrado grande propensão à transformação e à adaptação, que muitas vezes foge ao controle de seus praticantes. Apenas nos séculos XX e XXI, podemos listar inúmeras obras extremamente discrepantes entre si - nas quais traços, modos e vestígios do épico são perceptíveis, a saber: os poemas A Odisseia, de Derek Alcott, Mensagem, de

\footnotetext{
${ }^{1}$ Todas as traduções de textos que constam na bibliografia em sua versão original, isto é, em línguas estrangeiras, são de nossa autoria.

${ }^{2}$ Innes refere-se à epopeia modelada pelos gregos e normatizada por Aristóteles.
} 
Fernando Pessoa, O caderno de retorno ao país natal, de Aimé Cesaire, os romances Ulisses, de James Joyce, Guerra do fim do mundo, de Mário Vargas Llosa, Cem Anos de Solidão, de Gabriel García Márquez, as sagas - que posteriormente foram transformadas em filmes e séries de TV - Senhor dos Anéis, de J. R. R. Tolkien e Guerra dos tronos: crônicas de gelo e fogo, de George Martin. Cada uma delas apresenta um relacionamento diferenciado de ruptura e/ou continuidade com as matrizes clássicas.

Entretanto, para melhor debatermos a respeito do gênero épico, faz-se necessária uma breve discussão sobre os conceitos de gênero épico e de epopeia. A divisão tripartite dos gêneros literários postulada por Aristóteles dominou durante muitos anos os debates sobre os gêneros literários, em geral, e o épico, em particular. De todos os gêneros propostos pelo filósofo grego, o único que permaneceu estagnado critica e teoricamente foi o épico. A proposição crítica aristotélica para o gênero épico - baseada na leitura e apreciação das epopeias homéricas - foi encarada erroneamente como uma teoria do gênero, com um caráter fortemente prescritivo. A teórica Ligia Militz da Costa a sintetiza com precisão. Para Aristóteles:

Deverá [...] a epopeia a ser composta em torno de uma ação inteira e completa - com princípio meio e fim -, para que, como um organismo vivo, possa produzir o prazer que lhe é peculiar; sendo uma imitação narrativa em verso, ela terá uma estrutura diversa das narrativas históricas, que expõem não uma ação única, mas um período único, com os acontecimentos que nele ocorreram, ligados apenas por nexo causal e afetando a uma ou mais personagens.[...] A epopeia possui uma característica própria que permite ampliar sua extensão: ela pode relatar várias partes do mito que se realizam simultaneamente. Com isso, a epopeia avoluma-se e enriquece, podendo variar e diversificar os episódios e, assim, cativar o ouvinte, livrando-o da uniformidade entediante (COSTA, 1992, p.37-38).

Aristóteles examina toda a produção literária grega e reitera a excelência de Homero inúmeras vezes, apontando-o como modelo. Ressaltamos, então, que os postulados aristotélicos se referem somente ao corpus por ele analisado. Tomados e propagados por seus discípulos, eles adquirem uma feição de teoria normativa, coibindo, assim, o surgimento de teorizações e o reconhecimento e a legitimação de novas manifestações do gênero épico (SILVA \& RAMALHO, 2007, p.48). Dois pontos precisam ser frisados aqui: o fato de Aristóteles referir-se à epopeia, (e não ao gênero épico) e o fato de a epopeia e o gênero épico serem considerados quase sinônimos, sendo um a expressão formal do outro. 
Assim, essas ideias acabam por estabelecer uma noção rígida do gênero e por preconizar um modelo estanque e fechado de epopeia. Como os gêneros se ampliam e subdividem ao longo do tempo, a epopeia não pode mais ser escrita como nos termos estabelecidos por Aristóteles. Com a emergência do romance moderno, surge a ideia de morte da epopeia e, por conseguinte, do épico. O romance é apontado como seu herdeiro, muito embora ambos não tenham nenhuma relação genética. Após a ampliação da noção de gênero, a partir da crítica romântica à estética clássica, há uma laicização progressiva da categoria. Juntamente com essa laicização, passamos a conceber os gêneros em seu caráter sociointeracional, especialmente após as teorizações de Bakhtin, e a entendê-los como entidades dinâmicas e relativamente estáveis.

Deparando-se com essa nova concepção de gêneros e com um corpus de cunho evidentemente épico e que, no entanto, não se encaixa nos padrões aristotélicos, os críticos percebem a necessidade de rever e atualizar a maneira como o gênero épico e a epopeia são estudados. Surgem então teorias que, baseadas na noção de dinamicidade dos gêneros, percebem a epopeia como forma em mutação/evolução e que, por isso, recusam Homero como exemplo fixo e normativo, apesar de reconhecerem seu enorme e inevitável rastro de influência. O teórico Antônio Marcuschi afirma que:

A mobilidade dos gêneros permite dizer que caminhamos para uma hibridização ou mesclagem de gêneros de tal ordem que podemos chegar a uma situação em que não mais haja categorias de gênero puro e sim apenas fluxo. Contudo seria inadequado considerar a mistura de gêneros como evidência de ausência de gênero. Pois é fácil perceber que só se misturam se mesclam e unem coisas que preexistem, isto é a hibridização é a confluência de dois gêneros (MARCUSCHI, 2011, p.25).

A essa ideia de dinamicidade associa-se outra, a de universalidade do "épos", fazendo com que haja uma dissociação entre o gênero épico e a epopeia. A epopeia deixa de ser vista como única expressão possível de expressão do discurso épico. Ela passa a ser vista como uma das formas, talvez a mais notória, a partir da qual ele se expressa. O crítico francês Paul Zumthor percebe a dificuldade de conceituar epopeia e afirma:

Definir epopeia não é simples. Refere-se esse termo a uma estética, a um modo de percepção ou às estruturas de narrativa? Alguns o relacionam a toda espécie de poesia oral narrativa, especialmente de argumento histórico, sem levar em consideração o tom solene ou a extensão. É conveniente distinguir, sem dúvida, a epopeia como forma poética culturalmente 
condicionada, logo, variável e o épico como espécie de discurso narrativo relativamente estável, definível por sua estrutura temporal, pela posição do sujeito [...] (ZUMTHOR, 2010, p.113-114).

Assim, Zumthor ressalta a dificuldade de se abordar o fato épico e acrescenta ainda que a concepção clássica de poema épico, da maneira como nos foi transmitida e imposta por estudiosos de Aristóteles, foi inspirada por uma ideologia de escritura, que acabou por levar à crença no caráter fixo de epopeia bem como à confusão entre os conceitos de epopeia e gênero épico.

Percebemos, pois, que o épico tem uma abrangência mais ampla que a epopeia, haja vista outras manifestações não devedoras da tradição homérica apresentarem caráter épico. Basta pensarmos nas inúmeras narrativas orais e cantigas heroicas de povos da África e da Ásia, que embora não sejam foco deste estudo, constituem exemplos inegáveis de uma vivência épica, isto é, a relação do eu com o outro e com o mundo social.

O crítico francês Daniel Madélenat, em estudo sobre a caracterização do gênero épico e da epopeia, defende uma relação de continuidade entre os gêneros e adota termos do vocabulário da área da genética para analisar a relação entre ambos. Segundo ele, “o épico ultrapassa a epopeia, ele é um 'genótipo latente', capaz de nutrir fenótipos (textos) variados, mutantes, magnetizados pela desmesura e a imensidão de um epos que assim encontra múltiplos ecos e novos sopros" (MADELENAT apud GOYET, 2009).

Analisemos os termos: genótipo é o patrimônio genético de um indivíduo presente em suas células, que é transmitido de uma geração para outra. É importante ressaltar que não podemos ver o genótipo de um indivíduo, mas podemos deduzi-lo através de cruzamento, teste ou da análise dos traços parentais e descendentes. Já fenótipo é a expressão exterior observável do genótipo juntamente com a ação do meio ambiente. Muitas vezes a influência ambiental provoca manifestações de fenótipo diferentes do programado pelo genótipo ${ }^{3}$. Voltemos, pois, à colocação de Madélenat: vemos nela que o épico é caracterizado como uma instância com certa estabilidade, que se apresenta a partir de modos e temas, em diferentes graus, na associação a formas distintas, que dão

\footnotetext{
3 Disponível online: https://www.ufpe.br/biolmol/GenMendel/Mendel1\&2extensoes/mendel1.htm. Último acesso: 21/01/2017.
} 
origem a múltiplas configurações para ele. São justamente essas configurações do épico na contemporaneidade que pretendemos analisar aqui.

Nosso principal objetivo nesta tese é investigar sobre a permanência do gênero épico na contemporaneidade e caracterizá-lo a partir do levantamento dos procedimentos estilísticos, temas e motivos que são reapropriados e modalizados em diferentes gêneros. Também pretendemos analisar a maneira como essas diferentes configurações do épico se relacionam com as matrizes épicas clássicas e com outras questões como, por exemplo, as do mito fundacional e do clássico.

Para levar a cabo a discussão proposta, escolhemos um corpus ficcional composto por quatro obras: Uma viagem à Índia, do português Gonçalo M. Tavares (2010), Viva o povo brasileiro, do brasileiro (1984), de João Ubaldo Ribeiro, A odisseia de Penélope, da canadense Margaret Atwood (2005) e A Odisseia de Homero segundo João Vítor (2013), de Gustavo Piqueira. As obras, cada uma delas pertencente a um gênero diferente, representam configurações do gênero épico que se consubstanciam por diferentes estratégias narrativas, seja pela reaproriação paródica do gênero ou por meio de alusões e diálogos intertextuais.

$\mathrm{O}$ primeiro capítulo se divide em duas partes principais. Na primeira, discutiremos o conceito de clássico a partir de um levantamento dos sentidos adquiridos pelo vocábulo ao longo dos séculos. Extremamente polissêmico, o conceito de clássico nos auxiliará na reflexão sobre as mudanças percebidas pelo gênero épico. Discutiremos os paradoxos referentes à sua situação na contemporaneidade e seu uso e abuso em diferentes áreas de conhecimento. Já na segunda parte, discorreremos sobre a trajetória percorrida pelo gênero épico desde a epopeia grega até as possibilidades de configurações contemporâneas. Nesta parte, ainda discutiremos acerca do equívoco que é a ideia de morte da epopeia e de uma suposta relação genética entre ela e o romance moderno. Além disso, faremos uma breve exposição de teorias que admitem um dinamismo no gênero e tentam pensá-lo na contemporaneidade na clave de sua transformação e de sua incorporação por outros gêneros. Os postulados de Emil Staiger, Cecil M. Bowra, J. B. Hainsworth, Anazildo Vasconcelos da Silva e Chrsitina Ramalho, Saulo Neiva, Florence Goyet, Frank Kermode, Salvatore Settis, Linda Hutcheon e Carlinda Nuñez servirão, entre outros, como a base teórica para nossa discussão das questões abordadas. 
No segundo capítulo, analisaremos a obra Uma viagem à Índia, de Gonçalo Tavares. A obra, lançada e comercializada como "a primeira epopeia do século XXI", realiza um intenso diálogo intertextual como Os Lusíadas, de Luís de Camões. Analisaremos como a partir desse diálogo com Camões, Tavares desconstrói o gênero da epopeia e parece aderir à sua matriz mais em seu aspecto formal do que em seu conteúdo e tratamento do tema. Ao retratar a viagem do personagem Bloom à Índia, o escritor discute a possibilidade da existência da epopeia e de elementos vindos de seu universo. Por isso, discutiremos, ainda, se a obra pode ser caracterizada, de fato, como uma epopeia e o modo como desloca noções épicas de herói e nação.

No terceiro capítulo, discutiremos, em um primeiro momento, como o romance Viva o povo brasileiro, de João Ubaldo Ribeiro se insere numa tradição da literatura brasileira, a da narrativa de fundação. Essas narrativas, em geral, apresentam um inegável cunho épico, uma vez que abordam questões caras ao gênero, como a formação identidade coletiva nacional e a formação da nação. Depois, faremos um levantamento dos procedimentos estilísticos, temas e motivos típicos da poesia épica, reapropriados e subvertidos por Ubaldo em sua obra.

No quarto capitulo, abordaremos a novela A odisseia de Pénélope, de Margaret Atwood, na qual a escritora se reaproria da Odisseia, de Homero, e de sua tradição mítica, conferindo-lhe nova roupagem. Atwood posiciona a personagem Penélope como narradora e assim reescreve a obra sob um viés feminista. Dessa forma, analisaremos como esse viés feminista influencia a reescritura paródica da epopeia e como os modos do gênero épico se engendram nela.

No quinto capítulo, teremos como foco a obra A Odisseia de Homero (segundo João Vítor), do escritor e designer Gustavo Piqueira. A obra, voltada para o público infanto-juvenil, propõe uma leitura da Odisseia, de Homero, realizada por um adolescente. Por isso, refletiremos sobre o papel das adaptações infantis dos clássicos e sobre a possiblidade de elas serem uma manifestação do épico na contemporaneidade. Para tanto, realizaremos um levantamento das estratégias narrativas paródicas utilizadas por Piqueira tanto no nível textual quanto no imagético.

Comparar gêneros distintos - um romance, uma novela, uma obra infantil e uma possível epopeia - sob o mesmo enfoque, pode à primeira vista parecer 
incongruente, mas temos como parâmetro comparativo as matrizes épicas clássicas, em cuja natureza reconhecidamente híbrida predomina a instância narrativa em detrimento da lírica. Assim, o cotejamento das obras em sua relação com a matriz épica se justifica, haja vista que as três se notabilizam pela narração de histórias. Além disso, por pertencerem a gêneros distintos, acreditamos que a leitura e análise das obras nos garante um panorama mais amplo das configurações do gênero épico na literatura contemporânea. 


\section{2 \\ O clássico e o épico: sensores dos tempos}

\section{1 \\ O clássico, um conceito polissêmico e controverso}

Pois o que são os clássicos senão o registro dos mais nobres pensamentos do homem?
Henry David Thoreau

Quando um escritor se torna um clássico, já não há necessidade de lê-lo, basta citá-lo.

Roberto Gervaso

Vemos na contemporaneidade muitos sinais da presença do clássico nas mais diversas áreas e campos de conhecimento. Levando-se em conta a cena artística nos últimos anos, podemos citar como exemplos da reapropriação do paradigma clássico: a instalação Ulisses (2012), do artista plástico José Rufino, realizada na Casa França-Brasil, no Rio de Janeiro, a recente montagem da peça Trágica.3, de Heiner Muller, as recentes publicações de inúmeras reapropriações paródicas da Odisseia e o lançamento de blockbusters como Hércules (2014) e Pompeia (2014). Essas intervenções artísticas constituem marcas indeléveis tanto da presença do clássico na arte contemporânea, como também do grande interesse que ainda desperta na contemporaneidade, fruto de uma busca por referenciais.

Por outro lado, são cada vez mais comuns publicações cujos pareceres invariavelmente sombrios descrevem a decadência do ensino do grego e do latim, chamando atenção para o encolhimento de seus departamentos nas universidades. A classicista inglesa Mary Beard, em seu artigo "Do the classics have a future?" observa o crescente número de publicações que "de diferentes maneiras lamentam a morte dos clássicos, realizam uma autópsia neles ou recomendam algum procedimento atrasado para salvar-lhes a vida.” (BEARD, 2012, p.5). Essas ideias reverberam de tal forma nas discussões acerca do status do clássico na contemporaneidade que, em novembro de 2011, uma petição internacional foi lançada pelo instituto italiano Accademia Vivarium Novum para solicitar à 
UNESCO que tanto o latim quanto o grego fossem considerados patrimônio imaterial da humanidade. ${ }^{4}$

Podemos, portanto, observar aqui um paradoxo: os clássicos ainda se mostram muito presentes e despertam grande interesse na arte contemporânea, ao mesmo tempo em que os estudos do grego, do latim e de suas respectivas literaturas perdem gradativamente espaço nas universidades. Ou seja, cada vez conhecemos menos os clássicos, muito embora sua presença entre nós seja notável e marcante.

Tal questão é bastante complexa e, para melhor examiná-la, precisamos nos debruçar sobre a origem e o sentido do termo "clássico". Certamente controverso e polissêmico, o termo, de acordo com Penguin Dictionary of Literary Terms, pode se referir "a algo de primeira linha e autoridade; a uma obra pertencente à literatura ou à arte greco-romana ${ }^{5}$ ou ainda a um escritor ou obra de primeira linha, cuja excelência é geralmente reconhecida."(CUDDON, 1999, p. 138). Assim, vemos que 'clássico' se refere, em geral, a algo excepcional e/ou grecoromano antigo. Outra definição, estabelecida pelo crítico polonês Wladislaw Tatarkiewicz (1958), acrescenta que o termo "denota um estilo histórico, para se referir aos modernos que imitaram modelos antigos" ou ainda designa "uma categoria estética, que se refere a autores e obras que apresentam harmonia, medida e equilíbrio" (TATARKIEWICZ apud SETTIS, 2013, p. 205).

A palavra 'clássico' é derivada de classicus, vocábulo latino que quer dizer classe, divisão, repartição. O termo era utilizado para designar os cidadãos de classe alta, de acordo com a classificação dos cidadãos romanos em um censo promovido por Sérvio Túlio (578-535 a. C.). O vocábulo aparece pela primeira vez referindo-se à literatura na obra do gramático latino Aulo Gélio na expressão 'classicus scriptor, non proletarius', utilizada para designar o escritor de classe alta ou ainda de alta qualidade, em contraste com 'escritor de classe baixa' ou 'de pouca qualidade'. (HARVEY, 1998, p.122). Assim, o termo 'clássico' não se afasta por completo da conotação política de sua origem quando, no século II d. C., por

\footnotetext{
${ }_{5}^{4}$ https://vivariumnovum.net/unesco/appello.pdf

5 O crítico Salvatore Settis (2013 p.205) ressalta do fato de o vocábulo não se referir exclusivamente à Antiguidade Clássica greco-romana uma vez que, "em línguas europeias, é aplicado a inúmeras esferas que só apresentam, quando muito, uma tênue conexão, com a antiguidade greco-romana, e até mesmo com culturas não relacionadas a ela". Settis dá como exemplo os clássicos chineses e os períodos clássicos da arte pré-colombiana. Entretanto, a conexão com a esfera greco-romana adquire um lugar de destaque, em parte pelo caráter de exemplo e influência na educação das elites e pela origem do vocábulo, de que trataremos a seguir.
} 
empréstimo, passa a ser usado para designar algo que é "digno de apreciação literária". Ou seja, algo que tem valor como literatura e que deve, por isso, ser preservado, reproduzido e traduzido. Tal valorização se dá porque a obra apresenta valores sociais entendidos como norteadores, que funcionam para os indivíduos de determinada sociedade como marcas de reconhecimento mútuo.

O crítico Henrique Cairus observa que o clássico nasce "como um olhar específico para o passado construído a partir de uma projeção de um presente no futuro." (CAIRUS, s/d, p. 2), ligando-se, portanto, às ideias de permanência e referência. Ainda, para Cairus, o clássico encontra-se "cercado de um sistema de valores que estabelece com ele uma relação de sustentação mútua. Essas referências e permanências só fazem sentido em um projeto de identidade" (CAIRUS, s/d, p.3). Assim, vemos três pontos cruciais desta primeira acepção da palavra e que a acompanharão ao longo dos séculos: um caráter permanente, um status de referência norteadora e sua centralidade para um projeto identitário.

O termo desaparece no latim tardio e também durante boa parte da Idade Média. Quando ressurge, passa a ser utilizado para se referir àquilo que era estudado nas escolas. Nessa acepção, o clássico seria o objeto adequado para o estudo de determinada classe escolar. Surge, aqui, a noção de escritores essenciais, que, pela tradição, acaba por se tornar sinônima a escritores antigos, em particular escritores gregos e latinos. O clássico adquire, desse modo, uma conotação acadêmica e torna-se aquilo que serve como modelo, que tem um padrão de excelência (MAFRA, 2010, p. 16-17).

Esse caráter modelar conferido ao clássico permanece e é reforçado no Renascimento europeu, especialmente, na Itália, quando os paradigmas gregos e latinos são revisitados e celebrados, ganhando centralidade na representação artística. Graças ao trabalho de eruditos, há uma tentativa bem-sucedida de recuperação de sua forma e estrutura originais, além de sua disseminação, de forma jamais vista até então, por meio da remanufatura de repertórios gregos e latinos clássicos e da produção de novas obras que maximizam os efeitos plásticos e artísticos dos seus padrões. O clássico constitui, então, um repertório potencial cujas práticas e elementos são adotados por artistas que realizam escolhas que são “primariamente governadas pelo princípio da funcionalidade em relação ao novo contexto no qual esses elementos clássicos seriam enxertados, mas também indicavam a auctoritas do modelo clássico.” (SETTIS, 2013, p.50). Aqueles que 
se engajaram na recuperação desses artefatos culturais julgavam estar se apropriando de sua herança perdida (KRAYE, 2013, p.810).

Assim, além de modelar, 'clássico' passa então a designar os paradigmas culturais de origem greco-latina. Nesse momento, tais padrões haviam sido profundamente alterados por gerações anteriores, após muitos séculos de influência do Cristianismo. O mundo europeu medieval não tinha "mais os meios para se reportar às fontes gregas e às tradições plásticas e literárias" (BRISSON, 2015, p.287), o que havia gerado uma profunda alteração das formas clássicas gregas e latinas. Assim, tornam-se indissociáveis a ideia de clássico e a noção de Renascimento, a ponto de Settis afirmar que "um nunca poderia ter existido sem o outro, um nunca poderia ser explicado sem o outro" (SETTIS, 2013, p.66). Ambos formam, assim, um relacionamento simétrico e servem de guias na compreensão da história cultural europeia.

Os dois últimos sentidos apresentados de clássico - o de como autor lido e comentado nas escolas, o de modelo inspirador e repertório - permanecem em voga nos séculos XVI, XVII e XVIII. Entretanto, temos mais um sentido de 'clássico' no século XVI, com a emergência do Classicismo ${ }^{6}$. Mais do que modelo inspirador, ele se torna, aqui, referencial. Os paradigmas clássicos são encarados como elementos de um passado de caráter modelar, que por isso não devem ser estudados apenas, mas devem informar e fortalecer o presente. Entre seus elementos fundamentais, além da visão de que autores gregos e latinos servem de modelo artístico, podemos elencar: "os princípios de intemporalidade do belo e da necessidade das regras, o gosto pela perfeição, pela estabilidade, clareza e simplicidade das estruturas artísticas" (SILVA, 1973, p. 438).

O filósofo Pedro Duarte observa que muito embora o talento pessoal e a inspiração fossem elementos importantes para os poetas e artistas classicistas, eles deveriam ser subordinados às regras e aos ideais da perfeição clássica. Segundo o crítico, a forma como a Poética foi recebida no século XVI fez com que Aristóteles soasse mais normativo que filosófico, fazendo com que seus postulados fossem vistos como preceitos privilegiados para nortear tanto a prática artística quanto a crítica. Assim, "o passado clássico era tomado como ideal a partir do qual se julgaria a arte, fazendo-a aderir no presente à tradição, [...] que

\footnotetext{
${ }^{6}$ Tal denominação surge somente no século XIX, com o movimento romântico.
} 
tirada do mundo clássico, pretendia-se eterna e universal”. (DUARTE, 2011, p.86, grifo nosso).

Ao longo de três séculos, em diversos países, o classicismo literário estrutura-se de forma progressiva e, a princípio, dispersa. No entanto, consolida-se na França, onde é particularmente forte, nas mãos de artistas como Nicolas Boileau, Jean Baptiste Racine e Pierre Corneille, conforme observa Afrânio Coutinho:

A corrente classicizante, inaugurada pelo Renascimento, encontrou na Itália do Cinquecento um clima ideal; detida, porém, durante o século XVII pelo barroco, atingirá nas últimas décadas do mesmo século na França, o seu ponto culminante em um movimento que foi, de facto, na literatura, o único Classicismo moderno, para, penetrando o século XVIII, pontilhar de tendências e escolas neoclássicas as diversas literaturas ocidentais a que vieram emprestar coloridos especiais às correntes racionalistas e 'ilustradas' que então triunfaram (COUTINHO apud SILVA, 1973, p. 443).

Somente com a emergência do Classicismo francês, que tem forte influência sobre as outras literaturas europeias, o culto ao clássico atinge seu ápice. Para os classicistas todo o impulso criativo deveria ser dirigido pela razão e, por conseguinte, toda sorte de excessos deveria ser evitada. Assim o clássico, com seu caráter universal, atemporal e invariável, adequa-se facilmente à mentalidade iluminista de então, pois "os seus princípios estéticos estão impregnados de um profundo racionalismo" (SILVA, 1973, p.442).

Contudo, com muitas transformações ocorrendo nas literaturas europeias, surge um desafio à concepção classicista de clássico, durante a Querela dos antigos e dos modernos, que tem início na França em 1684. Era uma batalha entre anciens (antigos) - que, como vimos, enxergavam nos clássicos um modelo admirável que deveria ser seguido - e os modernes (modernos), que argumentavam que "a literatura tradicional era um fardo para a criação, e escritores e artistas deveriam ser capazes de inventar algo completamente novo" (MANGUEL, 2008, p.115).

Vemos, dessa maneira, que se forma uma nova acepção de clássico, na qual ele passa a ser lido também como um paradigma oposto a romântico/moderno, uma vez que o movimento romântico a ele se opunha, visando romper com a pretensão universalista inerente à tradição clássica. Os modernos começam a questionar a superioridade incontestável que os clássicos conferiam à Antiguidade Clássica, argumentando, entre outras coisas, que “a acumulação de experiências 
no tempo poderia privilegiar o presente sobre o passado, tornando viável ver os antigos sem dobrar os joelhos" (DUARTE, 2011, p.87).

No entanto, essa visão antitética de clássico/antigo como paradigma oposto a romântico/moderno surge com o desenvolvimento do movimento romântico. Apesar de se oporem aos paradigmas de extração clássica - que envolviam a imitação direta dos autores da Antiguidade Clássica - os românticos não necessariamente se contrapõem a ela. Eles apenas posicionam o clássico como uma interrogação ao presente, não como num conjunto normativo de produção e conduta ligado ao academicismo. Assim, a visão anticlássica atribuída aos românticos não se sustenta.

Ademais, a maioria dos românticos europeus tem formação clássica e suas obras são fortemente influenciadas por ela. A própria crítica que realizam da Poética, de Aristóteles faz com que a obra, apesar de ser rejeitada, permaneça, de certa forma, ao mesmo tempo, como eixo norteador. Nas palavras de Duarte (2011):

Assim, ainda que estivessem focados na busca pelo novo, os românticos "são dominados pela reação, tornando-se ainda mais escravos da antiguidade que querem negar, pois no esforço de vencê-la, acabam por mantê-la como ponto de orientação contrastante com o presente" (DUARTE, 2011, p.100).

Além disso, é preciso mencionar a notável presença dos gregos no pensamento romântico, que, via de regra, os concebe como a fonte original para a qual os românticos deveriam direcionar o seu olhar. O alemão Friedrich Schlegel, por exemplo, defende a ideia de que a poesia moderna (leia-se romântica) deveria ser construída com base no estudo dos poetas antigos, apesar de negar qualquer possibilidade de imitação direta de seus modelos. Para Schlegel, "daquilo que os modernos querem é preciso aprender o que a poesia deve vir a ser; daquilo que os antigos fazem, o que ela tem de ser" (SCHLEGEL, 1997, p. 84). Então, vemos que, para ele, o papel da poesia seria o "de unir a essência do moderno com a essência do antigo" (FORNARO apud SETTIS, 2010, p.868), concebendo-se aqui o 'antigo' como um sistema fechado, por isso, inimitável, e o 'moderno' como algo sempre em curso. Assim, não constituiriam mais um par antitético, mas complementar.

Em discussão sobre o clássico, a crítica Carlinda Nuñez aponta o século XIX como crucial para o futuro do clássico e Hegel como o autor da mais ampla 
definição do fenômeno, que, em sua visão, é "marcado pela progressão que vai da forma de arte clássica (autorreferencializada) em si ao Ideal da Forma (as figuras mitológicas, triunfo de todas as formas) e à sua dissolução no romântico" (NUÑEZ, 2013, p.100). Hegel descreve o artista clássico como um gênio que vem de uma formação excepcional e a arte como uma totalidade livre cuja forma é resultado da interpenetração do espiritual e de sua corporeidade natural correspondente. Emerge uma nova concepção de clássico. Nas palavras de Hegel, ele "é o que significa a si mesmo, e, por consequência, se interpreta a si mesmo" (HEGEL apud NUÑEZ, 2013, p.100).

Outro crítico que desconstrói e relativiza a dicotomia clássico-moderno é o poeta francês Charles Baudelaire, que em "O pintor da vida moderna" dá à dicotomia 'antigo/ moderno' uma nova dimensão, ao situar a discussão na relação que as obras - antigas e modernas - têm com o presente:

O passado é interessante não somente pela beleza que dele souberam extrair os artistas para os quais ele era o presente, mas igualmente como passado por seu valor histórico. O mesmo ocorre com o presente. $\mathrm{O}$ prazer que obtemos com a representação do presente devese não apenas à beleza de que ele pode estar revestido, mas também à sua qualidade essencial de presente (BAUDELAIRE, 1995, p.851).

Destacando essa proeminência do presente na configuração do moderno, o poeta ainda afirma que todo moderno está vinculado à captação do eterno no transitório, que é um traço fundamental para que chegue a se tornar antigo (clássico): a partir de tal afirmação, depreendemos que todo clássico - antigo para Baudelaire - já foi moderno em seu tempo por captar a essência dele (BAUDELAIRE, 1995, p.851).

No fim do século XIX, aos poucos, a polarização ‘clássico x moderno’ se dissolve, dando lugar a uma posição historicizante "em que as artes antigas e modernas pertenciam às suas respectivas esferas próprias. O foco mudou [da discussão do clássico] para o que significava ser moderno e para novas maneiras de conceber a tradição" (GÜNTHENKE, 2013, p. 836). De maneira contraditória, quase simultaneamente, o clássico torna-se um campo de estudos demarcado como uma disciplina acadêmica que abarca 'toda' a Antiguidade Clássica - grega e latina -, sendo incorporado por universidades e escolas e se tornando o "idioma cultural por meio do qual as elites de inúmeros países, nações e línguas poderiam se identificar umas com as outras." (SETTIS, 2013, p.65). 
Nos séculos XX e XXI, T.S. Eliot (1944), Frank Kermode (1983), Hans Georg Gadamer (1960), seu discípulo Hans Robert Jauss (1974), e Salvatore Settis (2006) trazem-nos importantes contribuições sobre o clássico. No ensaio What is a classic?, antes de lançar sua definição, T. S. Eliot distancia-se da antítese 'clássico/romântico' e reafirma a existência de diversos sentidos para o conceito de clássico em diferentes contextos. Segundo Eliot, há duas acepções para o clássico: o universal, que para ele é sinônimo a greco-latino e "o que só é clássico em relação à outra literatura em sua língua ou de acordo com a visão de mundo de um determinado período" (ELIOT, 1944, p.10). O diferencial entre eles reside numa questão de maturidade linguística e sociocultural, que confere superioridade ao primeiro. Assim, segundo seu critério, Virgílio seria o grande clássico universal, haja vista os contextos maduros de produção de sua obra, que possibilitaram sua permanência, influência e difusão até nossos dias. Além disso, o crítico afirma que "é apenas em retrospecto e em perspectiva histórica que um clássico pode ser conhecido como tal" (ELIOT, 1944, 10). É interessante notar que, ao definir o clássico por seu rastro de influência, Eliot privilegia a literatura greco-latina e exclui a existência de um eventual clássico universal contemporâneo.

Frank Kermode (1983) questiona essa conceituação, afirmando que ela se baseia numa visão imperialista. Segundo Kermode, há obras que, de fato, se perpetuam a despeito dos processos de transformação histórica, mas, discordando de Eliot, ressalta que elas seriam sustentadas mais pela mística e relações de poder existentes em seu entorno do que necessariamente por critérios de maturidade do contexto de produção e universalidade. Ou seja, seriam, na verdade, sustentadas por uma narrativa imperial construída em torno delas. Procurando tomar distância dessa visão imperialista, Kermode estabelece duas abordagens por meio das quais tenta caracterizar o clássico. Na primeira delas, ele é concebido como livro fechado, do qual extraímos ensinamentos e atribuímos significado: um texto "que exige que o leitor use seu conhecimento para se aproximar de uma leitura do clássico possível para um contemporâneo informado do autor" (KERMODE, 1983, p.75). Assim, vemos que essa primeira abordagem traz a ideia de clássico como referência norteadora.

Já na segunda, Kermode ressalta um paradoxo que o clássico apresenta em si: passa por inúmeras modificações ao longo do tempo e, ainda assim, mantém 
sua identidade e status. Permite-nos, portanto, refletir simultaneamente sobre seu tempo e o nosso, pois adquire "sentidos contemporâneos a nós, que muito possivelmente um contemporâneo informado do autor não teria descoberto" (KERMODE, 1983, p.75). Em outras palavras: é um texto a partir do qual novos sentidos podem ser engendrados. Segundo Kermode, o clássico "não seria legível, e assim não seria um clássico se nós não pudéssemos de alguma forma considerálo capaz de dizer mais do que seu autor quis dizer" (KERMODE, 1983, p.80). Cabe-nos acrescentar aqui que os novos sentidos podem, entre outras maneiras, ser engendrados a partir de processos de releitura e reescritura.

Os elementos constituintes do clássico da definição de Frank Kermode aparecem também na que propõe o filósofo alemão Hans Georg Gadamer (1997) ao tratar da questão em Verdade e Método. Gadamer nos apresenta o clássico como um conceito supra-histórico, mediador entre passado e presente:

O que é clássico é aquilo que se diferenciou destacando-se dos tempos mutáveis e dos gostos efêmeros, é acessível de modo imediato, mas não ao modo desse contato digamos elétrico, que de vez em quando caracteriza uma produção contemporânea, na qual se experimenta momentaneamente a satisfação de uma intuição de sentido que supera toda uma expectativa consciente. Antes é uma consciência do ser permanente, uma consciência do significado imorredouro, que é independente de toda circunstância temporal, o que nos induz a denominar algo de "clássico", uma espécie de presente intemporal que significa simultaneamente para qualquer presente (GADAMER, 1997, p.431).

Por causa dessa definição, Gadamer recebe críticas de seu discípulo H. R. Jauss (1994), que argumenta que a distância histórica nos dá a impressão de que o clássico carrega em si uma verdade atemporal, algo que, para ele, não existe em seu contexto de produção, mas ocorre ao longo do tempo, a partir da abertura a novas perspectivas e mediações:

Mesmo o efeito das grandes obras literárias do passado não é um acontecer que se mediava a si próprio, nem pode ser comparado a uma emanação: também a tradição da arte pressupõe uma relação dialógica do presente com o passado, relação esta em decorrência da qual a obra do passado somente pode nos responder e "dizer alguma coisa" se aquele que hoje a contempla houver colocado a pergunta que a traz de volta do seu isolamento (JAUSS, 1994, p.39-40).

Cada época - assim como cada cultura - se reporta ao clássico e o filtra de acordo com seus valores e quadros de referência. Desse modo, seguindo a linha de pensamento de Jauss, os clássicos gregos e latinos, por exemplo, não nos remetem à Grécia ou à Roma antigas e falam ao presente. Ao contrário, somos nós que 
vamos a eles trazendo-os ao presente, redefinindo-lhes os sentidos. Como observa Beard, "somos os únicos falantes reais em nosso diálogo [com os clássicos]; fazemos dos textos clássicos um ventríloquo, somos nós que lhes damos alma" (BEARD, 2012, p.10).

Já em nosso século, o historiador italiano Salvatore Settis traça um panorama sobre o passado clássico, demonstrando como a ideia de clássico - e nosso relacionamento com ela - mudaram ao longo dos séculos. Settis destaca o fato de que o clássico pode ser considerado a linha divisória entre o moderno - que o rejeitava - e o pós-moderno. A inclusão de expedientes de origem clássica é componente fundamental da poética pós-moderna, que os emprega como demarcação de seu limite com a poética moderna. Conforme Settis observa:

Os projetos pós-modernos se referem a um modelo histórico extremamente simplificado, fundado na oposição binária entre o moderno e tudo o que o precedeu (percebido como um monolito). "Clássico" nesse sentido basicamente significa pré-moderno e pós-moderno, em uma temporalidade linear bastante comprimida (SETTIS, 2006, p.32).

Settis ainda salienta que, na pós-modernidade, a visão de história como um repositório de temas ganha terreno a cada dia. Nesse contexto, a história e, por conseguinte, o clássico são relegados a um papel instrumental, porque "tudo que se rotula como 'clássico' se presta de modo especial a um difuso emprego ocasional" (SETTIS, 2006, p. 15). Assim, vemos que o clássico fica reduzido a um uso léxico-ornamental, que empobrece a linguagem clássica. Porém, “pode ser redimido desse emprego instrumental caso se recupere e analise sua extraordinária complexidade e singularidade com a necessária exatidão” (SETTIS, 2006, p. 15).

Além disso, ainda em relação ao retorno do clássico na pós-modernidade, Carlinda Nuñez acrescenta que ele sinaliza que a exclusão da herança clássica por parte do moderno não foi completa e que este retorno não ser considerado verdadeiro:

Não cabe aqui a premissa de superioridade do clássico, nem rebaixar a modernidade e suas conquistas. A legitimidade da nova era que irrompe com o Humanismo (Blumenberg: 2008) dá como prova a irreversível autodeterminação do sujeito moderno - que não precisou renunciar ao mito para autointerpretar-se e ao mundo, em sua transformação. É na crispação do clássico com o moderno que devemos pensar a durabilidade do primeiro [...] e a irreversibilidade do segundo (NUÑEZ, 2013, p.102).

Dessa maneira, percebemos que o clássico - muito mais do que um repositório de valores universais ou um apanágio do passado - é um índice 
aferidor de nossa condição contemporânea. Seu status contraditório e problemático nos dias de hoje, ao qual nos referimos no início deste texto - de referência balizadora para obras de arte e de herança cultural ameaçada de extinção - só faz revelar alguns traços da contemporaneidade. A maneira como nos relacionamos com a Antiguidade Clássica - por meio de uma reverência estéril, alimentada por imagens e recortes descontextualizados, repetidos adinfinitum, próprios para o consumo imediato - leva à sua reificação e transformação em commodity, mas, também, à sua ressignificação e ao reconhecimento de sua vitalidade.

Após essa breve discussão sobre o conceito de clássico e suas transformações ao longo do tempo, discutiremos como elas reverberam no gênero épico, foco dessa discussão.

\section{2 \\ Gênero épico e epopeia: trajetória, caracterização e teorização}

\subsection{1 \\ As matrizes épicas clássicas}

Começaremos nossa discussão sobre o gênero épico a partir de Homero e de suas obras, haja vista que o nosso foco de interesse é o status do épico na contemporaneidade e seu relacionamento com a tradição clássica. Não trataremos aqui, portanto, de manifestações anteriores a Homero ou que estejam fora de seu escopo de influência. Tentaremos sintetizar o percurso histórico-recepcional realizado pelo gênero épico desde a Grécia Antiga até os dias atuais. Para tanto, partiremos das definições de 'épico' e 'epopeia', já abordadas na introdução, colocando-as em contraste com teorias contemporâneas, a fim de encontrarmos caminhos que nos permitam abordar com propriedade as múltiplas configurações das manifestações épicas com referência clássica existentes na contemporaneidade, foco maior desta discussão.

$\mathrm{Na}$ Grécia Antiga, os conceitos de epopeia e gênero épico são indissociáveis. De origem oral, a epopeia clássica se desenvolve a partir de uma necessidade de se reter e transmitir uma memória cultural coletiva. Nela, o 
rapsodo faz referência a um cabedal cultural quando canta ou recita seu poema e, assim, "proporciona a seu público o prazer de sentir que faz parte de uma nação heroica, de reconhecer-se nas velhas histórias transformadas em mitos coletivos" (BRITTO apud PEDROSA, 2000, p.124). Os poemas épicos desempenham, portanto, um importante papel na formação do homem grego na medida em que fazem com que se identifiquem, coletivamente, como herdeiros de uma grande tradição, específica, particular e afirmativa de uma identidade.

A epopeia já havia adquirido sua forma escrita e o status de tradição literária, quando Aristóteles realiza na Poética sua influente caracterização do gênero. Para o pensador grego, a forma é inferior somente às tragédias. Como já vimos na introdução, na obra, Aristóteles define a epopeia como uma imitação por meio de verso em métrica única ou mesclada, sobre assuntos sérios ${ }^{7}$, retratando o ser humano melhor do que é. O pensador grego ressalta a excelência de Homero e o aponta como modelo:

Homero, por conta de muitas outras qualidades, é merecedor de elogios, mas o é, sobretudo, por ter sido o único, entre os poetas épicos, a compreender o papel do próprio poeta quanto a tomar a palavra. De fato, o poeta deve dizer o mínimo possível em seu nome próprio, porquanto não é um ator ao agir assim (ARISTÓTELES, 2011, p.87).

Logo deu-se o estabelecimento de uma hierarquia não somente entre os gêneros literários, mas também entre as produções épicas. As epopeias homéricas tornam-se um paradigma a ser seguido, dando contorno ao que chamamos de matrizes épicas clássicas. Por causa da imensa repercussão da definição aristotélica, e de sua leitura por estudiosos como um conjunto de normas, ela norteia não somente a produção de epopeias até o século XIX, mas também as teorizações sobre o gênero, que são feitas em sua esmagadora maioria, mediante sua influência, com a observação e a análise dos textos homéricos.

Duas dessas teorizações - que enfocam as matrizes épicas clássicas - nos interessam bastante aqui: a de Emil Staiger, em Conceitos fundamentais da Poética (1974), e a de Cecil M. Bowra, em Heroic Poetry (1952).

Tomando como base as epopeias clássicas e os conceitos de gêneros literários estabelecidos por Aristóteles, mas referindo-se a eles como estilos, Staiger faz na introdução de sua obra uma importante ressalva: a de que não há

\footnotetext{
${ }^{7}$ Apenas falamos brevemente sobre a definição aristotélica aqui, pois já a esmiuçamos na introdução do trabalho.
} 
gênero puro. Dessa forma, a classificação de um texto como pertencente a um determinado gênero se dá por causa de uma preponderância dos fenômenos estilísticos típicos presentes nele. O teórico, então, realiza um inventário desses fenômenos estilísticos dos gêneros, afirmando que a essência do épico residiria na apresentação objetiva dos fatos. Tal objetividade é mantida por certos procedimentos e expedientes, como a extensão épica, caracterizada pelo hexâmetro, em virtude de sua gravidade e amplidão; o ritmo regular e o desenrolar progressivo; a grandiloquência; a rememoração de ações passadas, conservandose o afastamento temporal e espacial; a inalterabilidade de ânimo do narrador; a catalogação e as fórmulas estereotipadas; a linguagem apofântica e metafórica, de grande plasticidade; a autonomia e simetria entre as partes e o caráter episódico da narrativa $^{89}$. (STAIGER, 1974, p.76-118).

Já Cecil M. Bowra (1952) só entende o gênero épico no âmbito de uma oralidade anterior, denominando-o heroico. Bowra aborda elementos importantes na construção do poema épico, como a figura do herói e sua movimentação pelos planos histórico e maravilhoso; a caracterização do maravilhoso; e a estruturação formal por meio do estabelecimento de uma mecânica da narrativa épica e do uso de técnicas de composição. Bowra ainda retira dos poemas épicos sua importância histórica, mas ressalta sua importância cultural. Para ele, "a poesia heroica, com raras exceções, não pode ser abordada como se fosse o registro de um fato, pois, embora seus materiais sejam amplamente históricos, o arranjo, a adaptação não o são" (BOWRA apud VASCONCELOS \& RAMALHO, 2007, p.188).

A primeira grande modificação nessa tradição épica clássica, tão bem caracterizada por Staiger e Bowra, ocorre quando, a partir das ocupações dos territórios gregos pelo Império Romano, a Península Itálica começa a sofrer um processo de helenização cultural, isto é, de incorporação de artefatos culturais gregos à sua cultura, num movimento oposto ao que ocorre geralmente nas conquistas, pois "à medida que os romanos se tornavam dominadores pelas armas, eram dominados pela cultura dos vencidos" (MAFRA, 2010, p.110).

\footnotetext{
${ }^{8}$ A crítica Helena Parente Cunha oferece-nos um detalhado panorama das considerações de Staiger sobre os gêneros literários em seu artigo Os Gêneros Literários. In: PORTELLA, Eduardo.(org) Teoria Literária. Rio de Janeiro: Tempo Brasileiro, 1999, pp.93-130.

${ }^{9}$ Anazildo Vasconcelos da Silva e Christina Ramalho (2007, p.184) observam que Staiger, apesar de tomar a poesia homérica como sinônimo de gênero épico, ignorando a inegável evolução do gênero, como veremos mais tarde, enfatizou muitos traços que tornaram mais visível a própria permanência do épico.
} 
No século III a. C., a cultura literária grega começa a ter um grande impacto sobre Roma, por meio de uma tradução da Odisseia feita por um suposto exescravo de origem grega, chamado Livius Andronicus. A obra de Andronicus se perde com o tempo, mas faz com que Homero se torne um modelo a ser seguido num momento em que a literatura latina ainda se consolidava. Como afirma Jasper Griffin, "Homero, o manancial nascente da Literatura Grega, permanece como o padrão e modelo definitivo, e os romanos não achavam que sua literatura estaria madura até que possuísse um grande poema épico em latim" (GRIFFIN, 2010, p.15). Tudo o que havia sido produzido antes ali passa a ser considerado menor e fica relegado a um segundo plano, até cair no esquecimento, pois a ocupação maior dos estudiosos passa a ser a disseminação do cabedal cultural advindo dos gregos.

Diversas foram as tentativas de se reconstituir o grande poema épico latino. Muitos poetas fizeram suas contribuições, desviando-se da matriz homérica por conta de seu contexto de produção. Lançando mão de diferentes objetos, conferem-lhes tratamentos diversos, de modo que, segundo os teóricos franceses René Martin e Jacques Gaillard (1981), podemos distinguir três tipos de epopeia em Roma: as epopeias lendárias ${ }^{10}$, as semi-históricas ou histórico-lendárias e a histórica. Os teóricos as definem da seguinte maneira: epopeias lendárias seriam as que relatam sobre fatos distantes no tempo que escapam à investigação propriamente histórica, valendo-se de forma sistemática do maravilhoso para se caracterizar, mostrando o envolvimento de deuses nos assuntos humanos; já a epopeia semi-histórica relata sobre eventos recentes e propriamente históricos, embora ofereça uma leitura religiosa, semelhante à tradicional, dos episódios lendários; por fim, a histórica que se caracteriza pela recusa do divinomaravilhoso, dando aos fatos que relata uma interpretação racionalista, baseada na causalidade humana (MARTIN ET GAILLARD, 1981, p.29).

Dois séculos depois da tradução feita por Andronicus, Virgílio escreve, baseando-se nos textos homéricos, a Eneida "uma epopeia lendária, que celebra as explorações dos heróis troianos, fundadores míticos do povo romano" (MARTIN ET GAILLARD, 1981, p.33). Baseando-se no herói troiano Enéas, o poeta latino emula as epopeias homéricas em sua obra, que pode ser dividida em duas partes.

\footnotetext{
${ }^{10}$ As epopeias lendárias são as que mais se aproximam do paradigma homérico.
} 
A primeira, baseada na Odisseia, narra sobre a viagem do herói em sua fuga de Troia até a Península Itálica. A segunda parte, inspirada na Ilíada, retrata as batalhas pela conquista do Lácio. ${ }^{11}$ Apesar de ter Homero como paradigma, Virgílio realiza aqui algumas rupturas em relação ao modelo grego. Entre elas estão a instauração de sua identidade autoral - já que se apresenta autoconscientemente no texto - e a submissão da tradição literária épica grega às demandas políticas de um projeto imperial romano, representado pelo imperador Otávio Augusto. (INNES, 2013, p. 10-12).

Em seu governo, Augusto tinha como objetivo realizar um renascimento de Roma, que para se efetivar, demandaria uma mudança de comportamento e mentalidade de seu povo. Para tanto, o imperador consegue a colaboração de intelectuais - como Virgílio e Horácio - para o lançamento dos pressupostos ideológicos da renovação que propunha. De acordo com o pesquisador Salvatore D’Onofrio:

O autor da Eneida colaborou nos dois pontos principais da reforma de Augusto: o incentivo ao cultivo da terra e a exaltação do povo itálico, ensinando liricamente a técnica da agricultura e ilustrando poeticamente o mito da origem divina da raça romana, predestinada a ser dominadora e civilizadora do mundo. (D’ONOFRIO, 1981, p.56)

Aqui, a poesia épica já havia deixado de ser a narrativa tradicional dos fatos, mitos e lendas. Presta-se à tentativa política de regeneração de um povo, a partir da celebração artística do mito de sua origem divina. A epopeia latina também se diferencia do modelo grego por ser aquilo que chamamos de epopeia reflexa; seu processo de formação, erudito e artificial, é "produzido por uma sociedade evoluída, criada por um único poeta, sem o concurso da imaginação popular" (MAFRA, 2010, p. 110).

O tremendo sucesso de Virgílio baseado na qualidade poética e imagística impecável teve o efeito de inibir a produção de emulações de sua obra. As demais epopeias escritas em Roma não tiveram o alcance da Eneida. Com o poderio do Império Romano e o gradual desaparecimento da língua grega e de sua literatura, a obra de Virgílio torna-se, ao longo de toda a Idade Média, mais conhecida que a de Homero e corporifica a noção ocidental épico clássico por muitos séculos.

\footnotetext{
${ }^{11}$ Salvatore D’Onofrio ressalta que "o conceito de imitação que para nós tem um sentido depreciativo, pois implica ausência de originalidade, na época de Virgílio indicava capacidade artística" (D’ONOFRIO, 1981, p.66).
} 
Quando chegamos à Idade Média, vemos que o épico, em seu formato modificado por Virgílio, se encontra com outras tradições orais, das mais diversas origens. Com a propagação da escrita, antigos mitos e poemas orais são recuperados e consagrados à forma escrita. Entretanto, tal trabalho é normalmente realizado por religiosos e/ou eruditos, com um vasto conhecimento da epopeia latina, que certamente, influencia sua concepção e escritura. $\mathrm{O}$ escritor argentino Jorge Luiz Borges, ao abordar o poema heroico Beowulf, afirma que nele "incluem-se ou entrelaçam-se alguns versos da Eneida [...] O autor pegou uma antiga lenda germânica e fez com ela uma epopeia, seguindo as normas sintáticas latinas" (BORGES, 2002, p.14). É preciso ressaltar, ainda, que os poemas épicos heroicos ou sagas constituem um subconjunto de gênero épico, que narra "geralmente a história das aventuras pessoais de um único herói de um contexto feudal de guerras e batalhas" (INNES, 2013, p.74). Dessa forma, o foco aqui migra da comunidade (ou império) e se instala sutilmente no indivíduo.

Além disso, a tradição épica clássica é confrontada por noções cristãs de heroísmo e por outras categorias de pensamento que entram em conflito com o imaginário pagão dos mitos que as epopeias propagavam. Acontece, então, o processo de alegorização do material mítico amalgamado a outros substratos imagéticos, de modo que se convertessem em figuras simbólicas adequadas ao imaginário medieval. Como afirma Innes, "a inscrição medieval do épico remodela os contos não-cristãos e os contos cristãos anteriores com um verniz derivado de um ethos cristão anterior, especialmente derivado da alegoria" (INNES, 2013, p.14). Tal processo de alegorização da mitologia épica e de apropriação de seus expedientes narrativos se faz presente nas canções de gesta, nos romances de cavalaria, em geral, e notavelmente na Divina Comédia, de Dante Alighieri.

Já durante o Renascimento, o advento do Humanismo e o interesse em recuperar a tradição clássica estimulam o desejo de que o épico clássico revivesse. Ademais, essa mudança rápida também ocorre em virtude de um conjunto de fatores que envolvia a recuperação dos textos homéricos, a perda de popularidade das versões medievais do épico, a fragmentação gradativa da unidade cristã, e o crescente interesse nas novas terras que estavam sendo descobertas e colonizadas (JOHNSON, 2013, p.316). Assim, segundo W. Ralph Johnson, "Esses eram um lugar e um tempo em que Aquiles e Odisseu pudessem se sentir em casa" (op. cit, 
p. 316). Entre obras produzidas nesse contexto, estão Os Lusíadas, de Luís de Camões, e Orlando Furioso, de Ariosto.

A maior parte dos estudiosos do épico renascentista aponta-lhe duas peculiaridades. A primeira delas é sua tendência à incompletude, que é resultado da incompatibilidade do gênero com o tempo em que foi produzido. A epopeia nessa época é escrita para uma aristocracia do início da Era Moderna e passa a ser associada a ela, em um momento anterior à sua decadência e perda de poder. Tal fato poderia ter contribuído, consequentemente, ao ocaso do gênero nos séculos posteriores (INNES, 2013, p.109). Em geral, até aqui e mesmo após a Renascença, os poetas continuam a produzir obras baseando-se na tradição épica clássica - tomando os moldes da proposição aristotélica como guia. A apropriação dessa tradição culmina em Paraíso Perdido, de John Milton. Na visão de Johnson (2010), o poema "é o único que se destaca preeminentemente entre esses esforços, por testar os limites do épico clássico mais impiedosamente e romper com seu molde nesse processo" (JOHNSON, 2013, p.318).

Durante todo esse tempo, a despeito das modificações, a epopeia homérica permanece tanto como um paradigma a ser seguido por poetas quanto como um índice de aferição de qualidade a ser utilizado pela crítica. No século seguinte, temos a emergência do romance como forma popular e sua subsequente adoção de modo mais extensivo por escritores, enquanto a poesia épica, com seu formato fixo e restrito, normatizado por Aristóteles, é gradativamente relegada a segundo plano, o que leva muitos teóricos a decretarem sua morte.

\subsection{2}

\section{O épico, do surgimento do romance à contemporaneidade}

Dentre os defensores da ideia de morte da poesia épica, Georg Lukács ocupa um lugar de destaque por argumentar que, dadas as circunstâncias históricas de seu surgimento, "o romance é a epopeia de uma era para a qual a totalidade não é mais dada de modo evidente, para a qual a imanência do sentido da vida tornou-se problemática, mas que ainda assim tem por intenção a totalidade" (LUKÁCS, 2000, p. 55). Para Lukács, na modernidade, o sentido das coisas não é mais dado, 
como no universo do épico, mas deve ser construído, uma vez que a vida perdeu seu sentido imanente. O romance, nascido da desagregação da épica, "é a peripécia dessa busca, a odisseia de sua desilusão ou chegada, apesar de tudo, à plenitude de sentido" (MAGRIS, 2009, p.1024).

A impossibilidade de se desenvolver a épica também é aventada por Mikhail Bakhtin (1941). Para Bakhtin, uma das características distintivas do gênero épico é ter como objeto um passado absoluto, no qual "tudo está integralmente pronto e concluído" (BAKHTIN, 1998, p.411). Esse passado totalizante, necessário à épica, é incompatível com o romance, uma vez que ele surge em momento em que a civilização agrária e a ordem feudal se desfazem. Nesse mesmo momento, a lógica da modernidade pós-iluminista se instaura, caracterizada pelo individualismo e pela valorização da experiência pessoal, tornando a experiência de mundo mais instável, idiossincrática e secular. Ao contrário da epopeia, o romance:

requer uma visão de mundo centrada nas relações sociais entre indivíduos; e isso envolve secularização, porque até o final do século XVII, o indivíduo não era concebido como um ser inteiramente autônomo, mas como elemento num quadro cujo significado depende de pessoas divinas e cujo modelo secular provém de instituições tradicionais como a Igreja e a monarquia (WATT, 2010, p.89-90).

Tal visão é endossada por Daniel Madelénat, cuja teoria sobre o gênero épico veremos em breve. O teórico afirma que o campo da literatura não é mais acolhedor à epopeia: "nele, a poesia somente sobrevive curta e estrófica (...); a estética moderna do fragmento, do inacabado, do amorfo e do caótico menospreza a unidade do seu universo heroico e sua coerência." (MADELÉNAT, 1986, p. 248). Assim, pelas razões citadas acima, na visão desses teóricos, a poesia épica não teria mais espaço na sociedade moderna, tendo seu fim decretado, por se basear em um mundo totalizante no qual deuses decidiam os destinos e todos os papéis sociais estavam definidos a priori, sendo incompatível, portanto, com os "tempos modernos".

Entretanto, muitas obras literárias desafiam essa crença na morte ou obsolescência da épica. Obras que são extremamente discrepantes umas das outras, mas que apresentam um inegável escopo épico, demonstrando, assim a vitalidade e a força do gênero desde - e a despeito do - surgimento do romance. A fim de desconstruir aquilo que, a nosso ver, é um mito - a morte da epopeia e, por 
conseguinte, do gênero épico ${ }^{12}$ - várias teorias foram criadas, todas investindo na ideia do gênero épico como uma instância não-estática e em constante transformação, o que lhe permite passar por várias reconfigurações. Em geral, os postulados sobre a sobrevivência do gênero épico nos permitem pensá-lo em duas claves: a da reconfiguração dinâmica da epopeia e a da modalização e incorporação do épico por outras formas e gêneros.

Os críticos Anazildo Vasconcelos da Silva e Christina Ramalho (2007), com sua teoria da semiotização do discurso épico, apontam para o fato de que as teorizações que aventam a morte da épica. Assim como em muitas outras reflexões sobre o gênero, Silva e Ramalho não reconhecem épicos que se engendrem fora do âmbito clássico. De acordo com os teóricos, a proposição aristotélica dos gêneros tem uma dimensão crítica particularizante, por se caracterizar pela reflexão sobre as manifestações do discurso épico, no caso, as manifestações epopeicas gregas clássicas:

O gênero épico, dentre todos os outros gêneros propostos por Aristóteles, foi o único que permaneceu critica e teoricamente estagnado, o que impediu o reconhecimento de um percurso independente da epopeia na formação da Literatura Ocidental. A proposta de Aristóteles tomada inadvertidamente com teoria do discurso épico, instituiu a manifestação épica clássica como padrão teórico para o reconhecimento de todas as manifestações do discurso épico, contribuindo, em parte, para a perda da perspectiva critico-evolutiva da epopeia. A formulação aristotélica restringe-se à epopeia grega, de modo que sua aplicação indiscriminada, através dos tempos, impossibilitou o reconhecimento de epopeias legítimas fora do âmbito clássico ${ }^{13}$ (SILVA \& RAMALHO, 2007, p.47).

De acordo com Silva e Ramalho, a legitimidade e adequação da teoria artistotélica estariam limitadas ao corpus analisado, não abarcando produções épicas posteriores, as quais não necessariamente reproduzem estritamente os expedientes da matriz clássica. Então, vemos que, se nos posicionamos ao lado de Silva e Ramalho, admitimos as manifestações do discurso épico posteriores às da matriz clássica e, assim, não seremos partidários da "afirmação inconsistente de que teria havido a fusão do curso da epopeia com o do romance, e [de que] o

\footnotetext{
12 Aqueles que aventam a morte da épica tendem a identificar a epopeia clássica como manifestação única do gênero épico. Portanto, com a extinção da epopeia em seu formato clássico, o gênero épico teria encarado inevitável esgotamento.

${ }^{13}$ Para Silva e Ramalho, "a matriz épica clássica investe o discurso épico nos quatro momentos da Retórica Clássica, gerando quatro modelos épicos: o clássico da Antiguidade greco-romana, em que tem início, o renascentista do século XVI e o árcade-neoclássico do século XVIII, em que se desenvolve, e o parnasiano realista em que se esgota" (SILVA \& RAMALHO, 2007, p.72).
} 
gênero épico teria se esgotado naturalmente" (SILVA \& RAMALHO, 2007, p.48).

A teoria de Silva e Ramalho (2007) defende a ideia de que, por ser dotada de uma dupla instância de enunciação - uma delas, narrativa, e outra, lírica -, a épica amalgama em si o gênero narrativo e o lírico. Uma vez que a especificidade do discurso épico se dá nessa articulação, a preponderância de qualquer uma dessas instâncias sobre a outra, não alteraria seu caráter épico. No percurso evolutivo que traçam da epopeia ocidental, os teóricos notam uma mudança: ao longo dos anos, a instância lírica começa a predominar sobre à narrativa. Além disso, estabelecem uma diferenciação entre epopeia e matéria épica - que, apesar de terem uma relação muito estreita, não se confundem:

Sendo a epopeia uma realização literária específica de uma matéria épica, fica implícita a pré-existência desta em relação à primeira. Tem-se na matéria épica a configuração de uma ideia ou temática que, impregnada no imaginário coletivo e social, suscita manifestações discursivas e/ou artísticas de natureza diversa [...]. Já a epopeia só existe como criação literária. [...] A matéria épica se faz autonomamente no nível da realidade objetiva e se dá pronta ao poeta que a realiza literariamente na epopeia. Isso deixa claro que matéria épica independe da epopeia, mas que a epopeia não pode prescindir dela, embora o reconhecimento da uma matéria épica, por si só não seja suficiente para definir uma realização literária da mesma como epopeia (SILVA \& RAMALHO, 2007, p.57).

Assim, a dupla instância de enunciação e a estruturação de uma matéria épica demarcam a natureza da epopeia, muito embora esses elementos não the sejam exclusivos. A epopeia se notabiliza "pela articulação conjugada desses dois elementos" (op. cit.p.67), que não têm um caráter fixo e que podem, por isso, prevalecer sobre o outro, sem, contudo, interferir na epicidade da obra.

Seguindo essa linha de raciocínio, os teóricos descartam a ideia de que os cursos do romance e da epopeia possam ter se fundido. Epopeias continuam a ser produzidas, elas só não se encaixam na definição clássica, que, segundo eles, é fruto de uma leitura distorcida da teoria aristotélica.

Outro teórico que defende a permanência da epopeia em nossos dias é o pesquisador Saulo Neiva, cuja busca por uma forma de teorizar sobre as expressões épicas na contemporaneidade e por questionar o conceito tradicional de epopeia, acabam nos dando contribuições preciosas sobre as atualizações do gênero. Em investigação sobre a obsolescência e a reabilitação da epopeia na modernidade, Saulo Neiva aponta para a sua situação paradoxal nos séculos XIX e 
XX. Neiva (2015) defende a ideia de que a epopeia continua a sofrer atualizações, por meio de poemas que:

são dotados de ligações diretas e deliberadas com a tradição épica ocidental, a qual eles reelaboram instaurando um diálogo estimulante e direto com um fundo comum de restrições formais, temas, modos, motivos que renovam os código da epopeia, contribuem, assim, com a transmissão e transformação desses mesmo códigos (NEIVA, 2015, p.204)

Entretanto, a fortuna crítica relacionada a ela encontra-se desatualizada, sem instrumental teórico adequado para examiná-los, uma vez que as teorias não contemplam a capacidade transformativa dos gêneros e opõem a epopeia ao romance. Para que uma atualização da fortuna crítica ocorra, é preciso substituir as teorias restritivas sobre a epopeia, vigentes há séculos, por outras que sejam suficientemente dinâmicas e levem em consideração as transformações por ela sofridas ao longo do tempo (NEIVA, 2015, p.205). Tendo isso em mente, o pesquisador define os poemas que supõe serem epopeias ${ }^{14}$ como longos poemas narrativos que têm a intenção de ir além:

do prosaísmo imediato para um canto federador através do relato de um passado coletivo, que implicam uma reflexão sobre o presente e uma tentativa de dizer a totalidade (de uma época, de um espaço, de uma família, de um clã, de uma nação). (NEIVA, 2015, p.206).

Guardadas as devidas proporções, tal definição vai de encontro ao que a francesa Florence Goyet (2008) propõe em seus estudos sobre as epopeias antiga e medieval. Segundo Goyet, a epopeia "é um gênero literário problemático, que busca pensar a história e que é capaz de refletir sobre as mudanças engendradas por uma época" (GOYET apud NEIVA, 2015, p.206). Em outras palavras: Goyet redefine a epopeia como um gênero que relata um passado coletivo e que possibilita a reflexão sobre a história sem se valer de conceitos fixos, de nação e identidade, por exemplo.

Neiva enxerga nessa visão menos restritiva de epopeia - que se volta menos para sua forma e mais para seu papel social - uma forma de abarcar a produção contemporânea, argumentando que:

A poesia épica moderna e contemporânea confronta também as visões de mundo disponíveis à sua época, de modo que permite ao leitor julgar cada uma delas, fazendo assim o teste de uma concepção, demonstrando sua

\footnotetext{
${ }^{14}$ Entre as obras elencadas por Neiva estão: Mensagem (1934), de Fernando Pessoa, A Odisseia (1938) de Nikos Kazantzakis, Diário de um retorno ao país Natal (1939), de Aimé Cesaire, Cantos (1954), de Ezra Pound, O Canto Geral (1950), de Pablo Neruda, Indes (1960), de Édouard Glissant e Omeros (1990) de Derek Alcott.
} 
validade e permitindo pensar a mudança. Ela nos parece dotada da complexidade que Goyet atribui a seu corpus antigo e medieval (NEIVA, 2015, p.207).

Assim, a partir dessa nova concepção, que se distancia dos postulados clássicos, a epopeia, considerada morta, é ressuscitada. As epopeias contemporâneas, ao se posicionarem em relação à tradição épica clássica, operam tanto a transformação como a transmissão dos códigos caracterizadores do gênero. Instauram, dessa maneira, um processo duplo de relações - entre si e com os textos anteriores - que Neiva distingue da seguinte forma: de um lado, esses textos se filiam diretamente a textos do repertório clássico, reapropriando-os dentro de sua perspectiva, evidenciando o percurso de memória que atualizam ${ }^{15}$. Por outro lado fazem, modificam a maneira como o leitor concebe a tradição genérica, ou seja, provocam um deslocamento na percepção de um texto já estabelecido (NEIVA, 2015, p.216).

Cabe-nos ressaltar que as teorias contemporâneas sobre a permanência do gênero épico que abordamos até aqui aventam a sua sobrevivência na contemporaneidade somente pela existência de novas epopeias, libertas da conceituação clássica e inseridas na lógica da transformação genérica. Os teóricos concebem a epopeia como sinônimo de gênero épico, visão com a qual não concordamos. Acreditamos que é possível negar a fusão dos cursos do romance e da epopeia e a ideia da morte desta, sem necessariamente refutar a noção de que os caminhos do romance e do épico podem se tangenciar e até mesmo se entrecruzar. Imiscuído também a expedientes romanescos, dada a extrema porosidade entre os gêneros na contemporaneidade, o épico sobrevive e dá origem a outras configurações épicas (que não podem necessariamente ser chamadas de epopeias). Esse ponto de vista é defendido pela crítica portuguesa Ana Mafalda Leite (1995).

Em sua obra A modalização épica nas literaturas africanas (1995), Leite aborda a presença do gênero épico nas literaturas africanas na atualidade. Para ela, o conceito de "epos é [...] universal, enquanto atitude religiosa do homem nas civilizações antigas. O conceito de epos, enquanto recitação de epopeia, é

\footnotetext{
${ }^{15}$ De acordo com Neiva: aqui, o poeta épico contemporâneo se posiciona também vis s vis com seus contemporâneos e nos convida a repensar um sistema de gêneros que o discurso crítico tende a caracterizar por meio de uma dupla hegemonia: a do romance, em detrimento de outros gêneros narrativos e o da poesia lírica, em detrimento de outras formas de poesia. (NEIVA, 2015, p. 216)
} 
posterior e particularizado de acordo com a cultura em que está inserido" (LEITE, 1995, p. 13). Portanto, ele não depende da tradição poética grega, embora esteja brilhantemente evidenciado nela. De forma semelhante a Silva e Ramalho (2007), Leite defende a ideia de que um gênero precisa se reorganizar em sua estrutura, em seus princípios fundamentais e seus procedimentos estilísticos de modo que se revitalize e abarque as necessidades do tempo e da cultura em que está sendo escrito.

$\mathrm{Na}$ articulação de sua teoria sobre o fenômeno de modalização do gênero épico na contemporaneidade, Leite baseia-se principalmente em postulados teóricos como os de Mikhail Bakhtin $(1978)^{16}$, Gérard Genette $(1986)^{17}$ e Alastair Fowler $(1982)^{18}$, para uma definição de gênero literário como instância de metamorfose e transformação. Para tanto, Leite vale-se da caracterização histórico-sociológica de gênero realizada por Bakhtin - principalmente por sua ordem transformacional - e entende que "o gênero literário como uma entidade evolutiva, cujas transformações ganham sentido no quadro do sistema literário, e na relação desse sistema com as mudanças operadas no sistema social" (LEITE, 1995, p.27).

A partir dessa premissa, Leite nos chama atenção para a observação que Genette (1986) faz de que toda a divisão de modos em Platão e Aristóteles estava estruturada com base nos modos de enunciação dos textos e que os gêneros dividiam-se pelos diferentes modos. Entretanto, com o passar do tempo, o uso do termo 'gênero' passou a ter outros empregos, dentre eles, o de designar 'modo', apesar de a distinção entre ambos ser feita desde os gregos. Para o teórico francês, os modos literários eram categorias meta-históricas. Já os gêneros literários eram eminentemente categorias históricas (LEITE, 1995, p.31). Leite ainda salienta que:

Para além desta distinção trans-histórica modal, que representa as possibilidades da enunciação e do discurso, há que se acrescentar um certo número de determinações temáticas e formais relativamente constantes e que constituem o quadro de evolução literária. Genette (LEITE, 1995, p.31).

\footnotetext{
${ }^{16}$ Bakhtin, Mikhail. Esthétique et théorie du Roman. Paris: Gallimard, 1978.

${ }^{17}$ GENETTE, Gérard. “Introduction à l'Architexte”, in Théorie des Genres . Paris: Seuil, 1986.

${ }^{18}$ FOWLER, Alastair. Kinds of Literature: an introduction to the theories of genres and modes. Oxford: Oxford University Press, 1982.
} 
A essa lista de determinações temáticas e formais, Genette adiciona categorias temáticas e os meios de imitação. Juntos, esses três elementos “determinam a reserva de virtualidades genólogicas com que a evolução literária faz sua escolha, e cujo grau de imprevisibilidade se manifesta, ora por mutação brusca, ora por transformação" (LEITE, 1995, p.32).

A definição de modo estabelecida por Fowler (1982) vem apenas a corroborar e, de certo modo, a enriquecer o pensamento de Genette: "Formas externas mudam rapidamente. [...] Os modos, porém, parecem ser destilações, dessas formas evanescentes, de aspectos permanentemente valiosos" (FOWLER apud LEITE, 1995, p.32). O modo, assim é pouco dependente da forma externa, mais versátil, sendo capaz de "entrar em novas misturas e continuar em combinação com gêneros ainda em evolução" (FOWLER apud LEITE, 1995, p.33). Enquanto o gênero passa por modificações ou se extingue, o modo - por ser trans-histórico, como quer Genette, - tem a capacidade de ser reintegrado e reinterpretado. Assim Leite consolida sua teoria sobre a modalização do gênero épico; ele se transforma em modo:

Modalização épica engloba o sentido transformativo e reactivador do gênero [...] e do modo [...], expressando a dinâmica de um processo que revitaliza e incorpora as formas estruturais do gênero épico e categorias temáticas que lhe são afins (o heroico), bem como a transformação do próprio gênero épico. (LEITE, 1995, p.37)

Assim sendo, percebemos que o gênero épico sobrevive também emprestando seu repositório de temas, formas e estruturas a diferentes gêneros textuais. Dito isso, vemos que, na contemporaneidade, podemos pensá-lo de acordo com duas chaves de leitura: a da transformação e transmissão genérica, advogada por Ramalho e Vasconcelos (2007) e Saulo Neiva (2015), com suas proposições sobre a permanência da epopeia, e a do investimento de outros gêneros, cuja maior contribuição é a teoria da modalização épica aventada por Ana Mafalda Leitte (1995). A exploração dessas duas chaves servirá para conduzir a discussão das obras selecionadas para nosso corpus, de forma coerente com nosso objetivo maior: traçar um panorama das configurações épicas hoje. Se nos propuséssemos a trilhar apenas um desses caminhos, estaríamos ignorando a amplitude das possibilidades e das manifestações do épico.

Em busca de compreender essas múltiplas possiblidades - "esse fenótipos de um mesmo genótipo épico", conforme aventado por Madelénat e discutido na 
introdução, analisaremos obras pertencentes a literaturas e gêneros diferentes, a saber: a epopeia ${ }^{19}$ Uma viagem à India (2011), do português Gonçalo M. Tavares, o romance Viva o povo brasileiro (1984), de João Ubaldo Ribeiro, a novela $A$ odisseia de Penélope (2005), da canadense Margaret Atwood, e a obra infantil $A$ Odisseia de Homero (segundo João Vítor) (2014), de Gustavo Piqueira. Nos próximos capítulos investigaremos a maneira como, nessas obras, os processos intertextuais de modalização e reapropriação ${ }^{20}$, das matrizes épicas clássicas se engendram.

\footnotetext{
${ }^{19}$ Veremos durante discussão desta obra que a sua classificação como epopeia é sujeita a debates. ${ }^{20}$ Utilizamos o termo "reapropriação" em vez de meramente apropriação, por considerarmos que não existe uso inédito nem exclusivo. Assim sendo, toda paródia, paráfrase, estilização ou plágio é uma reapropriação.
} 


\title{
3 O épico à deriva: Uma Viagem à Índia, de Gonçalo Tavares
}

Atribuir grandezas é sempre tarefa para a posteridade.

Mikhail Bakhtin

\begin{abstract}
A obra do artista pós-moderno é um esforço heroico de dar voz ao inefável e uma conformação tangível ao invisível, mas é também (obliquamente, através da recusa a reafirmar os cânones socialmente legitimizados e sua expressões) uma demonstração de que é possível mais do que uma voz ou forma e, desse modo, um constante convite a se unir no incessante processo de interpretação, que também é o de criação do significado.
\end{abstract}

Zygmunt Bauman

Autor de mais de 30 livros e ganhador de inúmeros prêmios, dentre eles o Prêmio José Saramago (2005), o Prêmio Portugal Telecom (2007) e o Prix Cévennes, de melhor romance europeu (2009), o escritor português Gonçalo Tavares apresenta em suas obras uma grande preocupação com a condição contemporânea do homem e explora em suas obras temas que lhe são relacionados, tais como o avanço e predomínio da técnica e suas consequências; o embate entre cultura e natureza, no qual se frisa a amoralidade da natureza e o poder coercitivo das organizações humanas, e a ausência ou busca de algum valor referencial, exterior e transcendente que seja superior e decisivo diante da existência do indivíduo (BORDINI, 2013, p.114).

A relação da escrita contemporânea com as obras do passado também é um tema de interesse de Tavares, como revela em entrevista concedida ao jornalista Carlos Vaz Marques, ao discutir sobre a literatura no século XXI:

Toda literatura aparece depois da literatura que já foi feita. E aparece não apenas depois da outra literatura; aparece depois da arte que já foi feita, do teatro que já foi feito, do cinema que já foi feito. Ou seja, não se pode escrever no século XXI como se não houvesse escritores e artistas nos séculos anteriores. E depois as artes plásticas ou o cinema ou o teatro são importantes para mim. É evidente que toda a tradição cultural está presente. [...] Há uma coisa que eu acho importante e que tem a ver com uma responsabilidade humana: a questão da conservação da memória. A única hipótese de conservarmos o antigo é tornarmos o antigo presente. Acho que isso é uma responsabilidade do escritor: dar sua atenção ao clássico (MARQUES, 2015, p.310).

Tavares demonstra, por meio de suas obras, esse senso de responsabilidade para com o clássico de que fala no trecho acima. Tal relacionamento ganha proeminência em seu livro Uma Viagem à Índia, publicado em 2010. 
A obra foi anunciada pela imprensa especializada e pelo mercado editorial como "a primeira epopeia portuguesa do século XXI". Nela o autor estabelece um forte diálogo intertextual com Os Lusíadas, de Luís de Camões, reapropriando-se, sobretudo, do formato em verso e da divisão em dez cantos. Alegando que a impossibilidade de recuperar a epopeia "é uma impossibilidade que ao mesmo tempo mostra a sua possibilidade" (MARQUES, 2015, p. 305), Tavares afirma que a epopeia tem uma riqueza que outros gêneros não têm e que "é evidente que uma epopeia no século XXI não pode ser igual à epopeia dos séculos clássicos" (MARQUES, 2015, p.305). Assim sendo, vemos que Tavares concebe a epopeia como um gênero dinâmico, passível de transformação.

No entanto, a crítica especializada, mesmo aquela que também crê no caráter não estático do gênero, questiona o status de epopeia dado à obra, classificando-a como romance escrito em versos. Baseando-nos em postulados teóricos propostos por Neiva (2009), Silva e Ramalho (2007), abordaremos a obra a fim de observarmos se é possível caracterizá-la como epopeia. Como já discutimos no capítulo 1, tanto Neiva (2009) quanto Silva e Ramalho (2007) defendem a permanência da épica em nossos dias, por meio da negação da matriz clássica como instância modelizante e da reestruturação genérica. Para os teóricos:

A dupla instância de enunciação e a estruturação duma matéria épica definem a epopeia, mas estes elementos não são de sua exclusividade. A matéria épica pode ser também realizada literariamente num poema, só com a instância lírica ou num romance, só com a instância narrativa, e o poema narrativo utiliza-se da dupla instância de enunciação para estruturar uma matéria romanesca (SILVA \&RAMALHO, 2007, p.67).

Assim, tendo em mente a dupla instância de enunciação e a matéria épica como traços imprescindíveis à epopeia, faremos algumas considerações acerca de status genérico de Uma viagem à İndia. Nas palavras do autor:

Uma viagem à India é um livro muito livre. Simultaneamente como essa liberdade tem a parte da estrutura. Há aqui um modelo de estrutura que equilibra as coisas. $\mathrm{O}$ começo [...] foi a construção do personagem: eu não sabia o que ele iria fazer e o que lhe iria acontecer. É um individualista do século XXI. Esta coisa do século XXI está muito marcada no livro. [...] O modelo é estruturante. Para quem conhecer bem Os Lusíadas, há um acompanhamento próximo - com muitos desvios, que têm a ver com Bloom que é do mundo da ficção, nada tem a ver com as descobertas (MARQUES, 2015, p.304-305). 
De fato, Uma viagem à Índia narra a trajetória de um homem comum, Bloom, de Portugal à Índia, remetendo-nos à viagem de Vasco da Gama retratada de forma heroica por Camões. A obra tem como subtítulo - "melancolia contemporânea (um itinerário)", ou seja, não trata de feitos grandiosos de um passado glorioso, mas da apatia e do esmorecimento da civilização ocidental no século XXI. Aborda uma era em que os indivíduos "sofrem, pode-se dizer, de uma crônica falta de recursos com os quais pudessem construir uma identidade verdadeiramente sólida e duradoura, ancorá-la e suspender-lhe à deriva" (BAUMAN, 1998, p.38). No prefácio à obra, Eduardo Lourenço se refere a ela como um antiépico:

O dispositivo de Uma Viagem à Índia é o de um poema provocantemente épico e anti-épico. A sua realidade é a de um romance não menos provocativamente inscrito nos "cantos" e "estâncias", ao mesmo tempo prosaicas e hiper-literárias pelos ecos de todas as peripécias que lhe são como um mar inacessível à plácida superfície do seu poema, total e totalizante (LOURENÇO, 2011, p.13).

Assim, a matéria de Uma viagem à Índia é uma realidade acima de tudo prosaica e romanesca, pois não se caracteriza pela presença de um herói representativo de uma coletividade. A obra parece ilustrar perfeitamente as considerações que Lukács faz sobre o romance:

o romance é a forma da aventura do valor próprio da interioridade, seu conteúdo é a história da alma que sai a campo para conhecer-se a si mesma, que busca aventuras para por elas ser provada e, pondo-se à prova, encontrar a sua essência (LUKÁCS, 2000,p. 91, grifo nosso).

Percebemos, pois, que o herói da obra configura-se como herói romanesco: Bloom parte em sua aventura para a Índia em busca de si mesmo, de sua essência, em um empreendimento individual. O personagem não é o representante de uma coletividade catapultado à imortalidade por seus feitos heroicos. É um homem comum dos nossos dias; não é personagem histórico nem pode ser alçado ao plano mítico. Para ser considerado épico, na visão de Vasconcelos e Ramalho, o herói precisa agenciar as duas dimensões da matéria épica, o que exige dele uma dupla condição existencial; a histórica, necessária para a realização do feito histórico; e a mítica, necessária para a realização do feito maravilhoso (VASCONCELOS \&RAMALHO, 2007, p.60). Bloom, o protagonista de Tavares, não cumpre nenhum dos dois requisitos. 
Além disso, precisamos ter em mente a visão de Bakhtin, que ressalta que a época contemporânea, por conservar o seu aspecto de atualidade viva, não pode servir de objeto de representação da epopeia, já que "o presente é algo de transitório, fluente, uma espécie de eterno prolongamento, sem começo, nem fim; ele é desprovido de uma conclusão autêntica e, por conseguinte de substância" (BAKHTIN, 1998, p.411). Para o crítico:

O mundo da epopeia é o passado nacional, é o mundo das "origens" e dos fastígios, da história nacional, o mundo dos pais e ancestrais, o mundo dos "primeiros" e dos melhores. [...] A epopeia jamais foi um poema sobre o presente, sobre seu tempo (ela atua somente para os descendentes como um poema sobre o passado. A epopeia como gênero definido e notório, desde seu início foi uma poema sobre o passado, e a orientação do autor [...], a qual é imanente e constitutiva da epopeia, é a orientação de uma pessoa que fala sobre o passado inacessível, a disposição devota de um descendente. O discurso épico é por seu estilo, tom e caráter imagético e está infinitamente longe do discurso de um contemporâneo que fala sobre um contemporâneo aos seus contemporâneos (BAKHTIN, 1998, p.405).

Dessa maneira, percebemos então que ao deslocar o tema da epopeia de um expediente histórico-mitológico para uma perspectiva romanesca - comezinha e individual -, Gonçalo Tavares não escreve uma epopeia contemporânea. Podemos afirmar, no entanto, valendo-nos da teoria da modalização épica de Ana Mafalda Leite, que o autor escreve um poema narrativo no qual o épico é modalizado e se engendra por meio de expedientes paródicos.

\section{1}

\section{Os Lusíadas: o hipotexto principal}

A narrativa de Uma Viagem à India é estruturada em uma relação intertextual e paródica com Os lusíadas, de Luís de Camões, em primeira instância, e com Ulisses, de James Joyce e a Odisseia de Homero, num segundo plano. A relação com a epopeia portuguesa tem caráter estruturante. Assim como Os Lusíadas, a narrativa em Uma viagem à Índia é dividida em dez cantos. Os cantos contêm o mesmo número de estâncias que os cantos da obra camoniana. São constituídos, porém, por versos livres, em sua esmagadora maioria, brancos.

Os Lusíadas já constituem uma transformação e um desvio da matriz épica clássica estabelecida por Homero. Escrita no século XVI, é, para Cecil M. Bowra, 
"a primeira epopeia, que em sua grandeza e universalidade fala ao mundo moderno.” (BOWRA apud MONTEIRO, 2010, p.119). À semelhança da Eneida, é uma epopeia reflexa. Camões escreve sua epopeia com a intenção de dar legitimação à "história portuguesa, desde suas origens míticas na Idade Média até a expansão mercantilista no Renascimento, dando ênfase à descoberta do caminho marítimo para a Índia, levada a efeito por Vasco da Gama entre 1497 e 1499" (TEIXEIRA, 2011, p.21).

Assim, apesar de Os Lusíadas não terem sido propriamente encomendados pelo Estado português, foram escritos de modo a preencher uma necessidade do estado mercantilista e expansionista, que sinalizava um processo de decadência à época. Camões expõe um ideário presente no discurso dominante no século XVI: a de que Portugal tinha uma missão civilizadora, que envolvia a disseminação do Cristianismo e de sua doutrina política. Tida como o épico nacional português, a obra celebra as viagens de descobrimento, que transformaram o país, nos séculos XV e XVI, em uma potência imperial e marítima. De acordo com George Monteiro: "Camões descreve o processo de construção do império, algo pertencente a um passado recente, historicamente um momento de grandeza nacional já em declínio enquanto o poema era escrito, publicado e lido" (MONTEIRO, 2010, 119).

Assim, a epopeia camoniana difere da clássica, entre outros aspectos, pela relativa proximidade da matéria narrada, que é trabalhada e se torna épica no processo de elaboração literária. $\mathrm{Na}$ acepção clássica, a epopeia envolve a narrativa de um passado distante, que apresente conquistas grandiosas, Camões se reporta a um tempo de fato grandioso e de conquistas - a Era das Grandes Navegações e dos chamados descobrimentos - e transforma a viagem de Vasco da Gama, conferindo-lhe um caráter heroico, incorporando ao plano histórico um aspecto mítico. O plano mítico é dominado por deuses da mitologia greco-latina. Lançar mão da inclusão de deuses pagãos em um poema sobre uma nação moderna e eminentemente cristã certamente foi um desafio para o poeta, que os apresentou em número bastante reduzido e lhes conferiu papeis importantes na narrativa, na determinação do destino de Vasco da Gama. Há praticamente a aparição apenas de Júpiter e Vênus, aliados dos portugueses, e de Baco, seu antagonista. (MONTEIRO, 2011, p.123) 
O crítico português António José Saraiva observa que nas epopeias reflexas, os deuses e "os heróis perdem a força e o relevo, em proveito de um destino ou providência, noção abstracta com que se justifica transcendentemente o estado" (SARAIVA, 1997, p.122). O processo é diferente daquele que ocorre nas epopeias primitivas, que emergem num momento "em que o grupo étnico se encontra em processo de expansão guerreira e em que as forças sociais, psíquicas e da natureza se apresentam aos membros do grupo como personalidades humanas" (SARAIVA, 1997, p.121). Dessa maneira, vemos que o estado assume o lugar do grupo étnico, logo, os deuses e heróis se convertem em alegorias para a uma noção abstrata de estado-nação.

Além disso, não somente a inclusão dos deuses do imaginário greco-latino conflita com a apologia ao Cristianismo. Segundo Ivan Teixeira, além dos episódios envolvendo os deuses, há inúmeros outros que não corroboram com o enaltecimento do ideal cristão por parte do estado português, tais como a violência das armas lusitanas contra povos desprevenidos. Entretanto não se pode esquecer que "na época, a expansão europeia do Cristianismo se confundia com o ideal de guerra santa" (TEIXEIRA, 2011, p.33).

O navegador Vasco da Gama se destaca n'Os Lusíadas como a grande figura heroica, muito embora seja apresentado em meio a outros heróis representantes de Portugal na viagem ao Oriente. Na verdade, Gama e seus companheiros são todos abordados menos por sua individualidade e mais como uma manifestação do caráter ilustre e grandioso do povo português. A crítica tradicional, por outro lado, o considera o herói oficial e narrador do poema (TEIXEIRA, 2011, p.49). Na visão de George Monteiro, ao decidir que em sua obra Gama agiria como se fosse embaixador de seu rei e narrasse a história portuguesa para o rei de Melinde,

Camões, de forma bem-sucedida, através de escolhas e ênfase, deu forma ao passado histórico de Portugal. Os Lusíadas se tornaram a narrativa da nação sobre si mesma, um construto mitológico estruturado, basicamente, sobre um substrato de fatos reais. Audaciosamente, como um profeta, Camões até inclui relatos de eventos históricos que, no tempo da vida de Gama, não haviam acontecido ainda (MONTEIRO, 2010, p.123).

No entanto, a voz de Gama não é a única no poema. O crítico Salvatore D'Onofrio salienta a complexidade do ponto de vista no poema por causa das diferentes focalizações e distingue três visões primordiais no poema: o ponto de 
vista do eu-poemático, o do narrador onisciente e o das personagens-narradoras, dentre elas, Vasco da Gama. O ponto de vista do eu-poemático pode ser visto ao longo de toda obra, expressando-se em primeira pessoa. Está presente no exórdio $^{21}$ e nos epifonemas ${ }^{22}$, que "acusam a intervenção direta do poeta na obra" (D’ONOFRIO, 1981, p.125). Já o ponto de vista do narrador onisciente, típico das epopeias gregas, se refere em terceira pessoa aos fatos passados. É predominante no poema e tem um caráter objetivo e distanciado. As personagens narradoras, por sua vez, assumem a narração em certas passagens para quebrar a monotonia da narração em terceira pessoa. Aqui, o leitor "percebe os acontecimentos relatados "em imagem", através do ponto de vista da personagem-narradora. Por essa perspectiva, não é o narrador que vê a personagem, mas é a personagem que mostra ao narrador e lhe impõe sua visão das coisas" (D’ONOFRIO, 1981, p.126).

Tendo em vista essas múltiplas vozes em Os Lusíadas, a crítica Christina Ramalho classifica as falas do eu-poemático e das personagens como excursos e ressalta sua natureza lírica. Uma vez que, devido ao afastamento temporal, o eupoemático não pode atuar no mundo narrado, ele o presentifica, para tecer comentários pessoais. Dessa forma, ao inserir-se no narrado, ele

[E]labora uma matéria lírica abundante que, colocada na boca do herói [e de outros personagens], integra-a ao relato, participando assim diretamente do mundo narrado. Essa matéria lírica [...] constitui os episódios líricos. [...] Os episódios líricos não constituem, como se costuma pensar, uma aberração. Pelo contrário, satisfazem a exigência épica de transfiguração do relato (SILVA \&RAMALHO, 2007, p.78).

Assim vemos que Os Lusíadas apresentam um caráter polifônico, que é ressaltado em sua plurivocalização. Diversas vozes são entrelaçadas e, por vezes, se mostram contraditórias. Tal contradição não poderia ser explicada sem o recurso estilístico de múltiplos sujeitos de enunciação. Como afirma D’Onofrio:

Estamos perante um "eu-dividido", que ora idealiza a viagem do Gama, ora a julga à luz da história; ora enaltece os heróis e os reis de Portugal, ora denuncia os graves defeitos da gente de sua terra, ora relata a intervenção dos deuses pagãos nos acontecimentos portugueses, ora os considera divindades falsas e mentirosas (D'ONOFRIO, 1981, p.128).

\footnotetext{
${ }^{21}$ Parte inicial da epopeia composta por três outras partes: a proposição, a invocação e a dedicatória.

${ }^{22}$ Segundo Teixeira, epifonema é um procedimento retórico que consiste no "arremate edificante e sentencioso que se dá a um trecho literário" (TEIXEIRA. 2011, p.145).
} 


\subsection{A parodização dos procedimentos estilísticos e motivos épicos em Uma viagem à Índia}

Agora que já fizemos essa breve explanação sobre Os Lusíadas e sua configuração epopeica, analisemos a reapropriação paródica de Tavares realiza da obra. Já mencionamos que Uma viagem à Índia acompanha a estruturação da epopeia camoniana no que diz respeito aos cantos e à organização das estâncias. Além disso, é possível notar um paralelismo entre as duas obras no que diz respeito à ação. Há remissões aos acontecimentos principais de Os Lusíadas, seja no conteúdo das estrofes, seja nos temas por elas desenvolvidos.

Além disso, no que tange à temática, vemos o retorno ao tema da viagem iniciática do Ocidente rumo ao Oriente, tão caro à literatura portuguesa. Segundo Eduardo Lourenço, no prefácio da edição brasileira da obra, esse retorno:

é uma original revisitação da mitologia cultural e literária do mesmo Ocidente, não como um exercício sofisticado de desconstrução (que também é) mas como uma versão lúdica e paródica de uma quête, aleatória e como tal, assumida (LOURENÇO, 2010, P.9).

Entretanto, a viagem empreendida pelo protagonista de Tavares é não marcada pela exaltação à gênese da Nação portuguesa e de seu Império ultramarino, nem pela disseminação religiosa e da expansão comercial. O que vemos aqui não é a viagem que simboliza a vitória e glória de Portugal que, a partir do desbravamento dos mares bravios, acaba por definir e dar forma à identidade do seu povo.

Ocorre, na verdade, um processo de esvaziamento desse simbolismo. No período entre 2003 e 2010, Bloom, um homem do século XXI, empreende um deslocamento de Lisboa rumo à India em busca de esquecimento e sabedoria. Deseja esquecer e fugir da vida na Europa e dos sofrimentos causados pelo assassinato da amada, Mary, por seu pai, posteriormente morto por ele. Busca tornar-se sábio a partir da viagem, o que se revela uma ilusão, pois “o mundo inteiro que já não se oferece como salvação, é a totalidade do mundo que se encontra decadente, é o próprio Homem, a Humanidade, que se encontra decadente" (REAL, 2010, p.1) 
Assim percebemos que, ao se reapropriar da tradição épica ocidental, Tavares a utiliza para pensar o contemporâneo e para ressaltar ironicamente o desmantelamento das suas instituições e o desespero pela perda de sentido da vida, tendo Portugal como foco. Como observa o filósofo português Miguel Real:

Em Viagem à Índia, o lirismo e o epicismo de Camões são subvertidos em absoluto, em seu lugar fica o grande vazio, o grande Nada ontológico e psicológico de Portugal, a ausência de uma grande razão para Portugal perdurar a não ser em função do economicismo e do consumismo próprios da era da tecnocracia. Viagem à Índia assemelha-se ao "Livro dos MortosVivos" de que somos hoje a maior figura na Europa, momento auroral de uma nova civilização europeia, um novo Portugal, de que se desconhecem ainda contornos precisos e de que Gonçalo M. Tavares é, hoje, no nosso país, o maior cantor. Ao epicismo glorioso do Tudo, de Camões, sucede hoje, o epicismo tenebroso do Nada, de Gonçalo M. Tavares (REAL, 2010, p.1).

Tal epicismo tenebroso do Nada de Tavares é obtido a partir da desconstrução paródica da epopeia. Segundo a teórica canadense Linda Hutcheon, a paródia tem um caráter central para a escrita pós-moderna. Ela envolve a referência a obras do passado de modo a salientar a história das representações que parodia. Essa reprise paródica do passado tem uma natureza crítica:

Ela não é a-histórica ou desistoricizante, ela não luta com a arte do passado em seu contexto original e a remonta em uma espécie de mostra presentista. Em vez disso, num duplo processo de instalar e ironizar, a paródia sinaliza de que forma as representações do presente vêm das do passado e quais consequências ideológicas derivam tanto da continuidade e da diferença (HUTCHEON, 1989, p.93).

Hutcheon vai adiante e afirma que a paródia desafia nossas noções de originalidade artística, autoria e propriedade, trabalhando no sentido de tornar explícita a política de representação das obras e de problematizar seu valor. Para a teórica, a paródia pós-moderna não ignora nem despreza o contexto das representações do passado que cita, mas utiliza a ironia para reconhecer nossa distância e separação desse contexto. Existe de fato uma continuidade, mas ela é permeada por uma diferença irônica. Segundo Hutcheon, "não há nenhuma resolução das formas contraditórias na paródia pós-moderna, mas uma elevação dessas contradições a primeiro plano" (HUTCHEON, 1989, p.94).

Tendo em mente essa noção de paródia defendida por Hutcheon, que implica o reconhecimento da história e da política das representações a partir da ironia, analisaremos os procedimentos tomados por Gonçalo Tavares para a realização de sua obra. Começaremos, portanto, nossa leitura por sua 
reapropriação da estrutura tradicional da epopeia, divida em proposição, invovação, narrativa e remate.

A proposição épica promove uma espécie de ritual de iniciação de leitura. $\mathrm{Na}$ obra de Tavares, percebemos que ela se estende por mais de dez estrofes, Concentra-se, sobretudo, na reiteração negativa daquilo que não será "cantado" na obra: mitos e feitos grandiosos da cultura ocidental, como podemos ver abaixo:

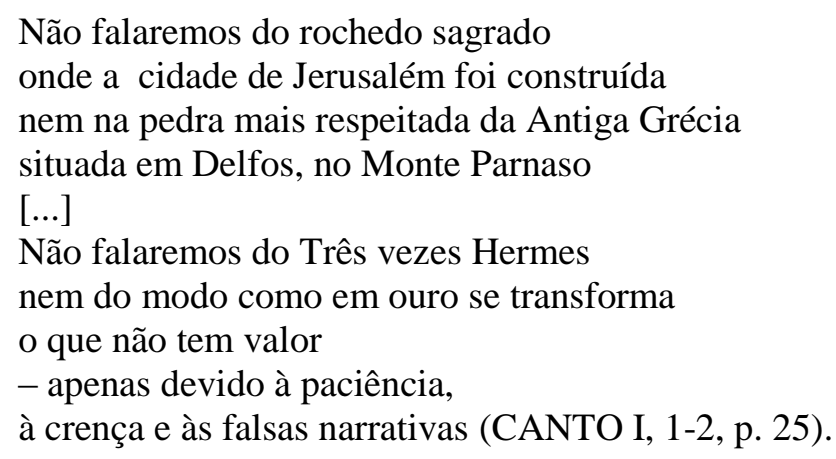

Entremeada nessa quase catalogação ${ }^{23}$ de temas que não serão cantados, vemos aos poucos, de forma dispersa, a revelação da matéria que será motivo do poema:

\section{Falaremos de Bloom \\ e da sua viagem à Índia. \\ Um homem que partiu de Lisboa.}

Não falaremos de heróis que se perderam

em labirintos

nem na demanda do Santo Graal.

(Não se trata aqui de encontrar a imortalidade

Mas de dar um certo valor ao que é mortal) (CANTO I, 2-3, p.25, grifo nosso).

Assim, percebemos que a proposição evidencia que a obra não tratará de feitos grandiosos, que garantiram a imortalidade a heróis valorosos, mas da vivência comum de um homem. O foco é colocado no plano individual, na figura de Bloom, homem sem representatividade e predicados para ser herói de um povo. Não há foco na coletividade, no povo e na nação, como é típico de epopeias, conforme se evidencia do canto I: "Não falaremos então de um povo/ Que é demasiado e muito./ Falaremos nesta epopeia de um homem: Bloom” (CANTO I, 44, p.40).

O crítico Luis Maffei ressalta que a proposição de Tavares tem um caráter extremamente irônico principalmente pelo contraste entre a profusão de negativas

\footnotetext{
${ }^{23} \mathrm{O}$ catálogo já é em si um recurso estilístico típico do gênero épico.
} 
e o número reduzido de afirmativas. Além disso, “ambas são ditas por um nós que não se encontra no assunto e sim na locução, ao contrário do que ocorre em $O s$ Lusíadas [...]” (MAFFEI, 2011, p.57). O uso da primeira pessoa do plural é irônico, pois é a partir dele que se revela a intenção de não narrar sobre um espírito coletivo.

Ainda na Proposição, temos a primeira rima na obra, mais precisamente na sexta estrofe do canto I: "Falaremos de um homem Bloom/ e da sua viagem no século XXI" (CANTO I, 6, p.27). O pesquisar Paulo Ricardo Vaz observa que, com essa inversão, cria-se um contraste com as matrizes épicas, de forma extremamente irônica e carregada de páthos, por ocorrer justamente na afirmação da matéria romanesca desenvolvida pelo poema, no momento em que o narrador revela que relatará sobre a viagem solitária de um homem comum em nosso século. De acordo com Vaz:

Na epopeia camoniana, os versos rimados são um elemento importante, porque é um dos aspetos que ajuda a sustentar a forma e o lirismo da obra, sendo que um dos principais objetivos será o da recuperação das formas clássicas. A inversão que aqui se cria é muito evidente, pois pela primeira vez no poema estamos perante uma rima (VAZ, 2014, p.45).

Se a proposição se caracteriza pela extensão e enumeração negativa do que será narrado, a invocação - que junto com ela forma o exórdio, nas epopeias clássicas, - está ausente. Tal ausência nada mais é senão um indício da condição contemporânea de descrença e melancolia que a obra de Tavares enfatiza. Segundo Christina Ramalho, "a invocação em geral está posicionada na abertura das epopeias, justamente por estar associada à necessidade de fôlego para dar continuidade a uma criação que exige iluminação e perseverança” (RAMALHO, 2014, p.41). Uma viagem à Índia, como já observamos, se distancia, em sua temática, do universo épico e se assenta numa visão de um mundo sem deuses:

Poderás acusar os deuses de serem possuidores de uma técnica de governo muito particular, que no fundo se poderá resumir dizendo: tudo deixa acontecer até o fim. Não poderás, pois, Bloom, atribuir demasiada complexidade a este modo alto de fechar os olhos, baixar os braços e repousar as pernas. São deuses, Bloom, não são o teu assunto.

Os deuses actuam Como se não existissem, e assim não existem, de facto, com extrema eficácia. 
Assim, Tavares se posiciona de modo a desconstruir qualquer intervenção mítica na narrativa. Os deuses já se encontravam em número reduzido em $O s$ Lusíadas em virtude da necessidade de celebrar os heróis portugueses; em Uma viagem à Índia, nem mesmo o herói é celebrado. De acordo com Bueno:

Diferentemente de Vasco da Gama, que parte rumo ao desconhecido, e que através de inúmeras peripécias, obtém o sucesso diante da conquista e através do heroísmo, Bloom filho de um tempo sem viagens [iniciáticas] possíveis, no qual a expectativa do desconhecido não acompanha o viajante, encontra ao longo de seu percurso, e no seu final, o tédio e a indiferença (BUENO,2013, p.6).

As intromissões de caráter mais lírico que o narrador realiza em Os Lusíadas apresentam também um espelhamento irônico na obra. Normalmente, no mesmo lugar em que essas intervenções do narrador ocorrem na epopeia camoniana, o narrador de Tavares antecipa episódios que acontecerão. Porém, como o texto carece do tom grandiloquente típico das epopeias, não o faz para mantê-lo nem por uma questão de simetria épica, mas para reforçar a atmosfera de tédio reinante em torno do personagem. Esses comentários em geral apresentam forte metaficcionalidade:

Gostava de um dia regressar a Lisboa, claro, mas já com alegria reencontrada e com uma mulher.

Mas que digo Avanço de mais. Antes de contar devo explicar, mas não serão as duas coisas uma única coisa Avanço, pois, e explico (ou conto) (CANTO III, 22, p.122)

Dessa forma, Tavares destaca a natureza ficcional e construída dos modos de representação literária, além de subverter um traço estruturante das epopeias. Nelas, evita-se a tensão a fim de se manter a simetria no relato e garantir maior independência entre os episódios. O narrador de Tavares quebra qualquer construção de expectativa por parte do leitor.

A natureza ficcional de Bloom é aludida diversas vezes pelo narrador, como no trecho a seguir:

Há que elogiar, nesta altura, a personagem central, o nosso herói: Bloom, Vem de uma tragédia familiar: Mary, a sua amada, por razões não totalmente claras, havia sido assassinada por ordem do seu pai, que Bloom sempre admirara, mas que logo matara em 
vingança. Sem amor e com sangue paterno nas mãos

Bloom havia decidido fazer uma viagem à Índia, mas, sensato, percebera que o importante era demorar muito tempo a chegar onde queria chegar. E tanta paciência depois de tanta violência, só pode ser admirada. (CANTO V, 86, p.234, grifo nosso).

O caráter autorreflexivo de um texto torna os modos de representação ficcional transparentes, chamando nossa atenção para sua natureza tradicionalmente opaca. A autorreflexividade da ficção pós moderna, salienta Hutcheon, "evidencia muitas das implicações da representação narrativa naturalizadas e geralmente não reconhecidas" (HUTCHEON, 1989, p.35). Entre essas implicações estão: os códigos pelos quais organizamos a realidade, os meios a partir dos quais organizamos as palavras numa narrativa, as implicações do meio linguístico que usamos para fazê-lo, o meio pelos quais os leitores são inseridos nas narrativas e a natureza de nossa relação com a realidade.

Em outra passagem, o narrador comenta de forma autorreflexiva sobre o desafio que sua narrativa representa para a tradição épica. Ele reconhece a importância dos clássicos gregos (que inspiraram todas as demais epopeias), mas reafirma seu impulso de subvertê-los:

É indispensável tornar conhecidas acções terrestres

Com o comprimento do mundo e a altura do céu, mas é importante também falar do que não é assim tão longo ou tão alto É certo que os gregos tentaram aperfeiçoar tanto a verdade quanto o gesto, porém as ideias foram de longe as coisas mais mudadas.

Eis o momento de colocar a Grécia de cabeça para baixo [...] (CANTO I, 11, p.28, grifo nosso)

Dessa maneira, Tavares revela no próprio texto sua intenção desconstrutora da epopeia como gênero, que ele assume como uma forma não estática e passível de mudanças ao dizer que "as ideias foram de longe as coisas mais mudadas".

O motivo da viagem, tão caro ao imaginário épico, é subvertido de inúmeras maneiras. Sua narrativa propriamente dita começa in media res, quando Bloom já deixou Lisboa e se encontra em Londres. Lá, ele se envolve em muitas peripécias, que beiram o burlesco e o picaresco. Bloom é atraído para uma armadilha por homens que querem roubar seus pertences. Esses primeiros episódios ressaltam a existência de um mundo cheio de perigos, caracterizado principalmente pela 
ganância presente nas relações humanas, sempre baseadas na obtenção de benefícios próprios.

Bloom então parte para a França, onde encontra com Jean M.. Relata ao francês o passado violento de sua família, marcado por brigas, confrontos físicos, traumas e mortes. De acordo com Bueno:

A acentuação da força psicológica somada às peripécias físicas no [herói] pode ser reveladora de um imenso vazio interno regido pelo tédio, de um movimento, inerte, que, ao colocar a personagem "para caminhar", aplicalhe um rasteira e o deixa caído no chão. A obra pontua pequenos desabamentos íntimos da personagem durante o trajeto da viagem (BUENO, 2013, p. 4).

Viagem essa que se estende ainda por outros lugares como Viena e Praga, que ocorrem na velocidade e profundidade de um pacote turístico. Bloom finalmente parte para a Índia, mas, antes, enfrenta uma tempestade a partir da qual o herói muda de postura: "E Bloom tem medo, Nunca vira antes a natureza/ revoltar-se violentamente [...]/ Bloom tem medo e reza (CANTO VI,80, p.274). Quando a tempestade passa, Bloom é tomado por euforia:

A tempestade marcara para Bloom um ponto final De uma coisa antiga. Estava pronto: partiria para a Índia. Estava pronto: partiria para a Índia.

O sol introduzira-se já entre as macieiras e laranjeiras dos pequenos jardins. E o sol introduzira-se também no aeroporto, rodeando os aviões que de novo pareciam pássaros poderosíssimos. Partiu, pois Bloom. A viagem era longa, mas a palavra longa tinha sido uma das que mais haviam mudado de sentido com tecnologia. A Índia estava por horas. Longas horas (a nível de espaço), mas horas (CANTO, 90, 277-278).

É interessante notar a ironia presente no fato de a viagem acontecer sem grandes sobressaltos num voo comercial, uma vez que ela é fruto uma reapropriação paródica e espelha a grande viagem de Vasco da Gama, cheia de mistérios e desafios.

Bloom chega à Índia finalmente. O herói, tão materialista, volta-se para o mundo espiritual. Diz o narrador: "O espírito existe. Bloom quer prová-lo" (CANTO VII, 12, p.289). Porém, não abandona sua visão de mundo, apenas parece disposto a transcendê-lo:

O mundo foi passear e perdeu o Espírito. 
Porém, Bloom não perdeu o espírito. Ele sabe que os grandes gestos surgem depois de um prolongado esforço de imobilidade e nada. A mão direita fará o seu melhor movimento depois de quarenta dias no deserto; assim como a mão esquerda. E Bloom sabe que existe ainda material atrás das pálpebras que deve ser aproveitado: os sonhos têm mensagens que se aproximam mais da verdade que a ciência. (CANTO VII, 13-14, p.289-290).

O herói entra em contato com o amigo indiano de Jean M., Amish, a quem pede que lhe relate sobre a India. Bloom a essa altura associa o país ao cultivo do espírito. Amish, corroborando sua antiga disposição de ânimo alerta que:

O mundo é redondo, mas todos os lados são iguais.

Os homens têm fome e adversários,

E outros prestígio e amigos e, nesta divisão rude,

Encontrarás semelhanças e evidentes

Com a velha Europa, a Ásia as Américas,

África, e com todos os continentes onde existem

Seres vivos. A vida é invenção dos demónios:

Deram-ta: deves defender-te, deves atacar

(percebes Bloom?) Percebo, responde Bloom com a cabeça (CANTO VII, p.300)

Amish o encaminha para um encontro com um líder espiritual, Shankra, que a princípio é receptivo a ele. É interessante notar que Bloom fala mais do que escuta o sábio. Ele relata ao sábio a decadência da Europa, caracterizada pelo predomínio da técnica e da ciência e da valorização do material. Segundo ele, ”o continente em espírito afunda-se, é certo mas ainda tem montanhas/ Afunda-se, é certo mas ainda tem helicópteros" (CANTO VII, 73, p.349). Pede, então, que Shankra lhe mostre a sabedoria da Índia, quando se depara como o Mahabarata e fica maravilhado. Tal comportamento desperta suspeitas nos discípulos de Shankra, que tentam colocá-lo contra o europeu. O mestre revela-se ambicioso: deseja adquirir os livros de Bloom - Cartas a Lucílio e o teatro de Sófocles. Tal negociação culmina num roubo, que traz Bloom de volta à antiga melancolia:

Bloom pensou: viajei tanto e tanto para agora terminar em negócios bibliográficos. Pensava (pensa Bloom) que sabedoria não tinha número de páginas, mas enganei-me. Há livros e livros a mais (pensa Bloom)

[...] Mas aceitou a troca dos livros: negócio feito.

Bloom já conhecia os estragos que o bom e o mau tempo europeus provocaram nos livros sábios, 
agora poderia perceber e cheirar o pó antigo da Índia

num velho livro. Mercadorias intelectuais

não deixam de ser mercadorias, mas pelo menos dão a ilusão de

uma certa grandeza.

Sempre fui colecionador - disse Bloom -

Aceito a troca e parto. Shankra sorriu (CANTO VIII, 81, p.352).

Como afirma Luís Maffei, "os três livros em negociação guardam textos antigos, anteriores à capitalização do livro enquanto objeto. E o fato é esse: os três livros [...] encontram-se em negociação, como se fossem objetos despidos de qualquer caráter supramercantil”" (MAFFEI, 2011, p.60). A negociação dos livros torna evidente que Amish tinha razão: a Índia não é o lugar do espírito. A viagem arquetipicamente épica não cumpre seu propósito:

Bloom [...] não contemplará a face de Deus ou as pegadas de Deus, que no espelho da Índia imaginava contemplar. Mas não volverá o mesmo. Agora sabe o que já pressentia. Que viajamos para nenhum paraíso. Que todas as viagens são um regresso ao passado de onde nunca saímos (LOURENÇO, 2011, p.11).

No retorno melancólico à Europa, temos as passagens da obra que espelham o episódio da Ilha dos Amores, de Os Lusíadas. Percebemos uma inversão bastante irônica do cunho utópico apresentado por Camões. Na obra camoniana, o episódio é apresentado como um prêmio concedido por Vênus pelos esforços de Vasco da Gama no desbravamento de um caminho marítimo para as Índias. De cunho sensual, o episódio da Ilha dos Amores pode ser considerado "uma versão poderosa e original de um dos temas mais populares da poesia antiga, o do locus amenus" (MONTEIRO, 2010, 125). Pode também ser visto como uma apoteose da viagem, pois nele os navegadores amam as deusas mais sensuais dos mares atingindo um conhecimento exclusivo aos deuses. Além disso, a deusa Tétis concede a Gama e seus homens a glória de serem apresentados "à imagem do próprio Deus cristão como centro da Máquina do mundo" (TEIXEIRA, 2011, p. 231-232). Como salienta Teixeira:

Independentemente do valor histórico da viagem de Vasco da Gama, a Ilha dos Amores representa o prêmio essencial ao esforço humano, uma espécie de glória que transcende o código específico da hierarquia e dos valores quinhentistas ou de qualquer época em particular. Simboliza o reconhecimento da utopia como forma de realização, que sempre foi a escolha de Camões. Talvez, por isso, alegorizando um pensamento íntimo o poeta tenha incluído uma láurea metafísica aos navegantes. [...] É possível que o poeta tenha posto a Ilha dos amores no final do poema, não apenas como prêmio à navegação do mar, mas também como exaltação à navegação 
do espírito, desempenhada tanto por ele ao compor o poema quanto por Gama ao ultimar a viagem. (TEIXEIRA, 2011, p.237-238).

$\mathrm{Na}$ obra de Tavares, as ideias de um futuro utópico e da transcendência metafísica do espírito encontram-se completamente subvertidas. Após a decepção na Índia, Bloom retorna com Amish para a França, onde é recebido por Jean M. O francês, cujo dinheiro cinicamente assume o papel desempenhado pelo Cupido em Camões, os recebe com uma reunião com prostitutas em uma casa alugada num bosque. No entanto, aqui, ele só tem a satisfação dos desejos carnais, não lhe é apresentada uma visão utópica de mundo futuro. Pelo contrário, Bloom chega a uma conclusão inevitável e já esboçada antes, em outras passagens do poema:

Bloom não tem ilusões: a viagem à Índia existiu. $\mathrm{O}$ futuro e o passado têm agora a mesma substância, nada mudou.

Valeu a pena viajar, pensa.

Pelo menos percebi que nada adianta (CANTO X, 10, p.420).

O futuro vislumbrado por Bloom é, portanto, distópico, uma repetição do presente e do passado. A mudança que desejava ter vivenciado a partir do deslocamento no espaço também não ocorreu. Esgotam-se, portanto, para ele, as possibilidades de olhar e vivenciar o mundo. Restam-lhe o tédio e o vazio. O episódio do bosque se prolonga até o retorno de Bloom a Lisboa. Lá, conjectura diversas formas de cometer suicídio até que é interrompido por uma mulher:

A ingenuidade é irrecuperável.

Bloom está em cima de uma ponte alta

e a noite esconde

os sapatos pretos. Nenhuma excitação

No corpo que regressou ao ponto de partida.

Há várias maneiras de um corpo se matar,

e cair do alto sobre a água é uma delas.

Uma mulher, entretanto, aproxima-se.

Bloom vira a cabeça; é uma mulher bonita, que sorri.

Não quer conversar?, pergunta ela. Bloom encolhe os ombros.

Ninguém em redor, silêncio completo, a água

lá em baixo por vezes um carro.

[...]

Ele aproxima-se da mulher e o mundo prossegue,

mas nada que aconteça poderá impedir o definitivo tédio de

Bloom, nosso herói (CANTO X, 155-156, p.452) 
Fica evidente então que tanto a viagem empreendida quanto o itinerário percorrido por Bloom se caracterizam pelo vazio, pelo tédio e pela imobilidade, sinalizadores da melancolia contemporânea.

Um ponto de crucial importância que não foi discutido até aqui é o diálogo intertextual que é estabelecido pelo escritor com o romance Ulisses, de James Joyce. Tal diálogo se dá a partir do nome do narrador: Bloom ${ }^{24}$, homônimo ao protagonista de Joyce. Publicado em 1922, Ulisses é considerado o ponto alto do Modernismo britânico e se notabiliza pelo experimentalismo da linguagem e por utilizar técnicas então inovadoras, como o fluxo de consciência e a fragmentação da narrativa.

Com o intuito de testar os limites do romance, James Joyce se reapropria do mito da Odisseia, de Homero, fazendo a ação toda se desenrolar em apenas um dia, na cidade de Dublin, em 1916. As críticas Carter e Mac Rae observam que na obra o "mais impressionante é o uso de Homero como modelo. Os personagens e episódios da obra têm paralelos nas histórias gregas, fazendo com que as comparações sejam deliberadamente cômicas ou irônicas" (CARTER \& MAC RAE, 1997, p.427).

Essa ironia se concentra, sobretudo, na caracterização do herói moderno. Ao se inserir na tradição épica clássica e reapropriá-la, O romance de Joyce reconstrói uma odisseia comezinha e individual, vivenciada por um homem comum. O escritor confere maior ênfase à personalidade do herói em detrimento de retratá-lo como símbolo ou abstração da nação ${ }^{25}$, como vemos, por exemplo, nas epopeias reflexas. Tal processo envolve, como afirma Bordini:

a retomada da centralidade da personalidade do herói (agora numa chave moderna baseada na individualidade) e a desconstrução (via parodização) do procedimento que faz do herói símbolo de abstrações associadas aos valores nacionais" (BORDINI, 2013, p.120).

Em suma, por meio da exploração realista dos limites do romance, forma moderna por excelência, Joyce aborda a falência do coletivo e do modelo tradicional de heroísmo épico, devidos à emergência moderna da individualidade, a qual celebra.

\footnotetext{
${ }^{24} \mathrm{O}$ nome Bloom já retira do personagem a ideia de representação do português, caracterizando-o mais como Europeu.

${ }^{25}$ Não estamos negando a presença de um comentário nacionalista feito por Joyce a partir de seu protagonista. Apenas estamos afirmando que ele fica em segundo plano.
} 
A desconstrução irônica que Joyce realiza a partir da obra de Homero certamente reverbera e encontra paralelos na relação que Gonçalo Tavares estabelece com Os Lusíadas em Uma viagem à Índia, apresentando, no entanto, suas idiossincrasias e diferentes resultados. Da mesma forma que o personagem de Joyce, o Bloom de Tavares também realiza uma viagem, que não é uma aventura coletiva. $\mathrm{O}$ escritor português modaliza parodicamente elementos do gênero épico, aplicando-o a uma matéria romanesca. Não narra a glória passada de uma coletividade, como Os Lusíadas fazem, mas apresenta o itinerário melancólico e pessimista de um indivíduo notoriamente ficcional. Ao contrastar as obras de Joyce e Tavares, precisamos ter em mente a noção de pósmodernidade como potencialização dos processos socioculturais modernos. O individualismo moderno - simultaneamente celebrado e problematizado por Joyce - chega de forma exponencial e extremada até Tavares, que o considera o mal do século $\mathrm{XXI}^{26}$.

${ }^{26}$ Cf. MARQUES, Carlos V. As palavras não se afogam ao atravessar o Atlântico. Rio de Janeiro: Tinta da China, 2015, p.312. 


\title{
4 \\ Viva o povo brasileiro: o épico reverso
}

\begin{abstract}
Tais como as narrativas, as nações perdem suas origens nos mitos do tempo e efetivam plenamente seus horizontes apenas nos olhos da mente.
\end{abstract}

Homi Bhabha

A história depende do ponto de vista do cronista. Ana Castillo

"Decidi ignorar essa possibilidade: o romance não é histórico, é apenas a minha história dessa história, história escrita por um nosso contemporâneo, com olho e visão de contemporâneo" (RIBEIRO, 1984, p. 98), afirmou João Ubaldo Ribeiro, ao discutir o processo de escrita de Viva o povo brasileiro, à época, ainda incompleto, no ensaio "Memória de Trabalho". A essa história alternativa a partir da qual problematiza o mito de fundação do Brasil, o escritor adiciona elementos maravilhosos para narrar sobre uma alma "que por azares de complexa descrição [...] sempre encarna em alguém do povo brasileiro e [...] termina por tornar-se, no final das contas, uma almazinha irremediavelmente brasileira" (op.cit, p.98). João Ubaldo, assim, promove a modalização épica de seu romance.

Antes de tratarmos propriamente da obra de Ubaldo, abordaremos as relações entre epopeia e romance. Como já discutimos, a noção de que o romance é um filho/substituto da epopeia na modernidade permeia a maior parte das discussões sobre as relações entre ambos. Tal ideia se assenta sobre o que o crítico italiano Massimo Fusillo classifica como mito crítico $^{27}$ : a noção hegeliana de morte ou obsolescência da epopeia a partir do surgimento do romance, o 'épico burguês'. Na concepção de Fusillo, essa formulação hegeliana, ao receber desenvolvimentos por Georg Lukács, tomou vida própria, pois:

ela estabeleceu o mito crítico (em óbvia necessidade de reconsideração hoje) de que o épico é uma forma primeva par excellence, o gênero que inaugurou a literatura e estabeleceu identidades nacionais por meio da poesia córica, impessoal e totalizante; e de que o romance, ao contrário, é uma forma secundária preeminente, um fragmento aspirando a uma totalidade perdida (FUSILLO, 2006, p.33).

\footnotetext{
${ }^{27}$ FUSILLO, Massimo. "Epic, novel". In: MORETTI, Franco. The novel: forms and themes. New Jersey: Princeton University Press, 2006.
} 
Assim, fixa-se uma dicotomia que não necessariamente corresponde à realidade, pois essa concepção estabelece "uma unidade primeva, da qual formas secundárias marcadas por desregramento e fragmentação descendem em uma linha evolutiva derivativa" (FUSILLO, 2006, p.34). Fusillo também ressalta que tanto a epopeia quanto o romance são modos de representação literária que pertencem à mesma tipologia expressiva, o regime narrativo, apresentando inúmeras subdivisões em gêneros e subgêneros. Entretanto, a epopeia é mais firmemente codificada e canônica enquanto o romance é mais fluido e aberto. Tal dicotomia, para Fusillo, é favorável e convidativa à hibridização entre eles.

Essa afirmação reforça nossa crença de que, apesar de ser uma forma bastante codificada e fechada, a epopeia pode sobreviver nos dias de hoje por meio do investimento de outros gêneros sobre ela, a partir da hibridização e da modalização de seus expedientes. Na contemporaneidade, esses processos de modalização épica ganham maior vulto no romance ${ }^{28}$, muito provavelmente por causa da fluidez de que nos fala Fusillo. Reforçando essa caracterização do romance, a crítica francesa Marthe Robert afirma que ele:

(...) não tem regras nem freio, sendo aberto a todos os possíveis, de certa forma, indefinido de todos os lados. É esta evidentemente a razão principal de sua expansão contínua, e também de sua voga nas sociedades modernas, às quais se assemelha, quando não por seu espírito inventivo, por seu humor buliçoso e vitalidade (ROBERT, 2007, p. 14).

Portanto, percebemos que o romance, como forma aberta que é, está apto e aberto a se associar a outras formas e discursos, sempre em processo de transformação, reapropriando-se de outras formas e sendo "a seu bel-prazer sucessiva ou simultaneamente, fábula, história, apólogo, idílio, crônica, conto, epopeia; nenhuma prescrição, nenhuma proibição vem limitá-lo" (ROBERT, 2007, p.13-14). Assim, como resultado da associação do romance à epopeia temos o chamado romance épico, que acolhe em si elementos tanto do épico quanto do romance. $\mathrm{Na}$ visão de Aparecido Rossi, o romance épico "não funde, não desarticula e nem desintegra um e/ou outro dos gêneros que o constituem. Antes, porém, permanece épica e romance ao mesmo tempo" (ROSSI, 2009, p. 150).

\footnotetext{
${ }^{28}$ Inúmeros são os casos de modalização épica no romance contemporâneo, entre os quais citamos: Cem anos de solidão (1967), de Gabriel García Márquez, Guerra do fim do mundo (1981), de Mário Vargas Llosa, A república dos sonhos (1985) e Um defeito de cor, de Ana Maria Gonçalves (2006).
} 
Viva o povo brasileiro, de João Ubaldo Ribeiro pode ser, sem sombra de dúvidas, lido como um romance épico ${ }^{29}$, uma vez que nele o escritor, além de lidar com a questão do mito de fundação brasileiro, dialoga com as matrizes épicas clássicas por meio de reapropriações paródicas de procedimentos estilísticos e estéticos, alusões a obras e mitos, reinserindo-os em outros contextos.

\section{1}

\section{Épico e mito de fundação em Viva o povo brasileiro}

Em 1984, quando da publicação de Viva o povo brasileiro, João Ubaldo Ribeiro já havia publicado três romances, Setembro não tem sentido (1968), Sargento Getúlio (1971) e Vila Real (1979), duas coletâneas de contos, Vencecavalo e o outro povo (1974) e Livro de histórias (1981) e uma obra voltada para o público infantil. Vida e paixão de Pandomar, o Cruel (1983). Nessas obras, considerando-se as proporções de cada uma, já eram visíveis o humor e a ironia que são a tônica de Viva o povo Brasileiro. Nada neles, no entanto, apontava para um romance de escopo épico. Aqui, Ubaldo nos apresenta uma narrativa histórica de eventos ocorridos na Ilha de Itaparica, que abarca quatro séculos: os eventos se desenrolam entre 1647 e 1977. A obra nos traz a memória da epopeia, trabalhando as questões do mito de fundação e da identidade nacional.

A epopeia marca uma origem gloriosa para a nação e celebra ritualmente a identidade cultural de uma comunidade. Ela é, segundo Innes, uma forma literária “com uma proeminência cultural crucial. Seu escopo se presta às grandes narrativas que incorporam vários mitos de origem misturados com memórias de eventos e personagens históricos" (INNES, 2013, p.1). É, portanto, uma narrativa fundadora que visa promover a coesão de uma comunidade e sublimar possíveis diferenças existentes por meio da narração de um passado glorioso comum. Tal coesão é promovida através da narrativa de um mito fundacional, isto é, de "uma estória que localiza a origem da nação, do povo e de seu caráter nacional num

\footnotetext{
${ }^{29}$ Silva e Ramalho (2007) argumentariam que Ubaldo realiza uma matéria épica valendo-se de expedientes romanescos.
} 
passado tão distante que eles se perdem nas brumas do tempo, não de um tempo real, mas de um tempo mítico" (HALL, 2002, p.54-55).

A crítica Lucia Helena aponta a existência de uma tradição das narrativas de fundação que permeia a literatura brasileira. Essas narrativas consistem em interpretações do Brasil feitas pela literatura, e são, antes de tudo, leituras de nossa identidade cultural. Com um caráter eminentemente épico, apresentam-se em momentos cruciais de nossa história. Elas, via de regra, articulam os planos mítico, histórico e ficcional para estabelecerem um relacionamento de reforço ou questionamento ao mito de fundação brasileiro:

Na literatura brasileira a vinculação entre o processo de textualização e o mito de fundação da cultura surge desde as crônicas da conquista, espraia-se em algumas obras épicas do século XVIII, mas é com o Romantismo, e com a valorização do romance (em suas várias espécies) como gênero maior, que surge uma tipologia de narrativa tendente a problematizar a questão da identidade cultural (HELENA, 1993, p.81).

Ainda, as narrativas de fundação na literatura brasileira têm um propósito de esquadrinhar um imaginário cultural coletivo e obedecem a uma dupla matriz. Por um lado, reforçam o tópico da origem, que inscreve uma origem localizável e concreta para o fundamento da nacionalidade. Por outro, estabelecem o tópico da rasura da origem, isto é, o questionamento de que a busca das origens fundadoras seja o melhor caminho para discutir a identidade nacional por causa do viés ideológico inerente a elas (HELENA, 1993, p. 83).

O tópico da origem na literatura brasileira advém de uma necessidade romântica de conferir ao país certa homogeneidade e obliterar diferenças e desigualdades internas, forjando num plano simbólico a identidade nacional. Instaurado, sobretudo, por José de Alencar com a publicação de Iracema, em 1865, ele sugere a existência de uma unidade consensual, sem fraturas ou fissuras, que se consuma na fundação da nação. Dessa necessidade, segundo Eneida Leal Cunha, surgem "as representações primordiais da etnicidade fictícia, que, nos meados do século XIX, constituiu-se da exclusão radical de negros ou da sua degradação na representação do país" (CUNHA, 2007, p.7). A essa exclusão do negro soma-se a reinserção do índio na história e o posicionamento do branco europeu como pai da pátria.

Em Viva o povo brasileiro, João Ubaldo alinha-se à vertente da rasura da origem por questionar a coesão da identidade nacional e problematizar o mito de 
fundação brasileiro, expondo seus vieses ideológicos. O discurso épico e a narrativa fundadora são inseridos no romance para sua subsequente desconstrução e ironização. Na visão do crítico João Ceccantini, Viva o povo brasileiro é

uma epopeia às avessas, em que a história do Brasil ressurge, não sob a perspectiva da 'História oficial' dos compêndios didáticos, cheia de vultos e heróis nacionais, mas por meio de um fio narrativo que coloca em primeiro plano anônimas personagens do povo brasileiro.(CECCANTINI, 1994, p.114)

No agenciamento do plano histórico em seu romance épico, Ubaldo parte de uma visão não-hegemônica de história por meio da qual chama atenção para o caráter artificial do ideal de identidade promovido pelo mito fundador, que ignora a noção de que:

Todas as identidades coletivas são construções mutáveis. Todas as bases - os símbolos, os relatos e mitos institucionais, os episódios decisivos, os heróis, ritos ou bandeiras - são elaborados e reelaborados de maneira contínua por meio de complexos processos de disputa e negociação. Neles se batalha para definir os limites do grupo e de seus valores, pois por mais coesos que estejam, por mais unidos e homogêneos, persiste neles a diferença, embora não se manifeste ou seja reconhecida (GOLDIN, 2012, p.98-99).

Ubaldo desafia o mito fundador ao desconstruir noções tais como genealogia, heroísmo e ao questionar a história oficial. Para tanto, utiliza expedientes e motivos épicos, parodiando-os.

A noção de genealogia inerente às narrativas fundacionais é desconstruída a partir da ideia de 'reencarnação de alminhas' desenvolvida na obra. As almas passam por reencarnações sucessivas, em seres de diferentes raças, instalando-se no "Poleiro das almas" enquanto aguardam encarnar. Ao contrário de obras de períodos anteriores da literatura brasileira nas quais o mito fundador é legitimado mediante o surgimento de uma noção unificadora de uma raça-síntese, em Viva o povo brasileiro, as ideias de continuidade e unificação são rompidas a partir da noção de reencarnação das almas. As almas podem reencarnar como pessoas de raças diferentes, apontando para uma multiplicidade de possiblidades do "ser brasileiro". Podemos conferir tal ruptura com a noção de raça-síntese na descrição das encarnações do alferes José Francisco Brandão Galvão, jovem alçado à posição de herói nacional após a morte:

Sim, que maior glória haveria para o povo do que ter sido esse herói inspirador e eloquente a primeira encarnação de uma almazinha nova, uma alma especialmente gerada para cimentar fortemente o orgulho de todos e 
exibir a fibra da raça? Assim, porém, não aconteceu (Viva o povo brasileiro, 2014, p.34RIBEIRO).

A alma do alferes já havia encarnado como indígena várias vezes antes, tendo inclusive habitado o corpo do caboco Capiroba, devorador de holandeses à época das Invasões Holandesas, na região da Ilha de Itaparica. Sua história de vida é contada logo após à do alferes, acentuando o contraste entre ambas. Podemos afirmar, portanto, que o fato de a mesma alma ter encarnado em Capiroba e Galvão, "além de deslocar a configuração da identidade brasileira produzida pela instituição da história nacional, encarnada no alferes, traz para o romance outros momentos de reflexão sobre o país e outras versões da diferença brasileira" (CUNHA, 2007, p. 9).

Ubaldo, por meio de sua escrita, põe em xeque e desautoriza as noções monolíticas de verdade, nação, heroísmo e história. A descrição dos eventos envolvendo a morte e heroicização do alferes são reveladores nesse tocante. $\mathrm{Na}$ narrativa, a elevação do personagem à categoria de herói da independência se dá depois de sua morte, resultado de um involuntário confronto com os portugueses. A partir da representação de sua morte em um quadro chamado " $O$ alferes Brandão Galvão Perora às Gaivotas", fixa-se a ideia de que o rapaz foi um grande herói na luta contra os portugueses. O crítico Geraldo Carneiro ressalta que na descrição da morte do herói, Ubaldo utiliza uma linguagem grandiloquente e a configuração clássica de narrador onisciente, comum às epopeias, em contraponto à crueza e à singeleza da vida de Brandão Galvão. Assim, a cada vez que "regressa ao terreno da epopeia, suas palavras passam a ser lidas também pelo avesso, configurando uma espécie de antiepopeia. E sua grandiloquência se converte em ironia" (CARNEIRO, 2014, p.17), como vemos no trecho a seguir:

Contudo, nunca foi bem estabelecida a primeira encarnação do alfares José Francisco Brandão Galvão, agora em pé na brisa na Ponta das Baleias, pouco antes de receber contra o peito e a cabeça as bolinhas de perda ou ferro disparadas pelas bombardetas portuguesas, que daqui a pouco chegarão com o mar. Vai morrer na flor da mocidade, sem mesmo ainda conhecer mulher e sem ter feito qualquer coisa de memorável. [...] Dos seus deveres de alferes nada conhecia, nem mesmo o que significava o posto, nem mesmo se era alferes (RIBEIRO, 2014, p.27).

Percebemos pela descrição que o narrador realiza da cena da morte, que o heroísmo de Galvão - em sua representação histórica oficial post-mortem - não encontra lastro ou evidência em sua vida: sua morte foi causada pela força das 
circunstâncias. A representação histórica é baseada na invenção de alguns fatos e no apagamento de outros, para que ele se torne herói, contribuindo com a construção de uma ideia de nação gloriosa.

Outra ocasião em que a obra de João Ubaldo desconstrói tanto o discurso histórico oficial quanto o épico é quando privilegia personagens vindas das camadas populares. Os heróis de Ubaldo não pertencem às camadas abastadas nem se destacam por seu renome. São, antes de tudo, anônimos. Não apresentam traços sobre-humanos, diferindo assim dos heróis épicos. Um bom exemplo é o bandoleiro Zé Popó. Ao perceber que nenhum membro da vastíssima família Popó se voluntaria para ir à Guerra do Paraguai, Zé se candidata. Desfaz, dessa forma, uma situação constrangedora para a família, haja vista que o pai, João Popó, havia prometido publicamente que seus filhos seriam os primeiros a se apresentar como voluntários, caso a guerra eclodisse. O filho parte para o campo de batalha, do qual retorna e ganha status de herói de guerra. Em uma cerimônia de premiação e de exaltação de seu caráter heroico, parece não aceitar a condição de herói:

A vergonha aumentou, quando, depois da entrega do diploma e das saudações, uma do presidente, outra do orador oficial, Zé Popó foi conduzido à tribuna e, em vez de entrar direto no assunto do dia, disse, em tom destituído de eloquência, quase chocho que não sabia o que falar. Que desejavam ouvir? Não imaginassem que a guerra era feita por pessoas diversas daquelas que estavam ali. Pelo contrário, dos praças aos marechais, era feita por pessoas como as que estavam ali, o mesmo homem que trabalha na paz trabalha na guerra. (VPB, 2014, p.473).

Em seu discurso, Zé Popó, já na condição de herói de guerra, desconstrói a noção épica de herói - também pretendida pelo discurso histórico oficial. Zé Popó ainda afirma: "mesmo depois de muitas horas de combate, mesmo depois de anos de guerra, o que se sentia era medo todas as vezes. Combatia-se apesar do medo[...]" (RIBEIRO, 2014, p.474). Assim, ressalta que os exércitos são formados por pessoas comuns e que, portanto, toda e qualquer tentativa de mitificação é ideológica.

Outra instância em que Ubaldo trata do caráter construído da figura do herói é ao retratar Perilo Ambrósio. Na mesma Guerra de Independência em que morre o alferes Brandão Galvão, Ambrósio mata um escravo e, utilizando seu sangue, finge ter sido ferido em uma batalha. É, por isso, nomeado Barão de Pirapuama, entrando para a história como herói de guerra: 
Sim, era, pensou Perilo Ambrósio. Eu sou um barão, disse mentalmente. [...] Quanta luta, quanto sacrifício, pensou Perilo Ambrósio, novamente enxugando o suor com o farto lenço brocado [...] Muito bem, de fato a Revolução premiara seus heróis. E de fato tinha sido muito mais fácil do que imaginara antes tomar de sua família todas as propriedades, mesmo quando, com o pai já capturado, preso e acusado de traição, encontrou o ouro em pó que se dizia estar enterrado ilegalmente nos fundos da casa grande do engenho. [...] Sim, a revolução premiou seus heróis, pensou outra vez Perilo Ambrósio, sopesando a frase, que achou elegante e expressiva. A alguns ela pagara em merecido dinheiro, como aconteceu, a mando do próprio lorde Cochrane, em Itaparica (RIBEIRO, 2014, p.48-49).

A conversão do dissimulado Perilo Ambrósio em herói de guerra entra para a história de Itaparica e suas consequências reverberam ao longo da narrativa. Ao retratar a construção forjada de um herói de guerra, Ubaldo chama atenção para a natureza discursiva da história, questionando seu status de verdade. Como afirma Lucia Helena:

Viva o povo brasileiro nos apresenta várias concepções de possíveis verdades "históricas" privilegiadas por diferentes personagens, estratégias e focos narrativos, cada uma delas integrando o plural de vozes que configuraria o perfil deslizante do nacional (HELENA, 1993, p.91).

\section{2}

\section{A parodização dos procedimentos estilísticos e motivos épicos}

Viva o povo brasileiro reedita a matriz épica de forma paródica, disseminando seus procedimentos estilísticos, motivos e temas no romance com um impulso irônico. No prefácio à primeira edição da obra, o escritor Geraldo Carneiro argumenta que ela propõe um exercício de descentramento constante e que, apesar de a linguagem se tornar solene em certas instâncias e estabelecer paradigmas, ela mesma os enfraquece e ridiculariza. Tais ideias de Carneiro ilustram e corroboram o que Hutcheon nos fala sobre as formas de arte pósmodernas que:

simultaneamente usam e abusam, estabelecem e depois desestabilizam convenções de maneira paródica, apontando autoconscientemente para os próprios paradoxos e o caráter provisório que a elas são inerentes, e, é claro para sua reinterpretação crítica ou irônica em relação à arte do passado. (HUTCHEON, 1991, p.43) 
Vemos, dessa forma, que João Ubaldo estabelece em sua obra um jogo de reverência e deslealdade à matriz épica clássica, usando e abusando de seus expedientes para miná-los. Carneiro, como já dissemos, a classifica como uma "antiepopeia", mas preferimos a concepção de Cecantini - de que é uma epopeia às avessas - pois consideramos que este termo ressalta que os traços do épico estão presentes na obra, estabelecidos juntamente aos do romance para serem subvertidos.

Ubaldo adota em seu romance uma narrativa episódica, mantendo uma relativa autonomia entre as partes. Procedimento típico da épica clássica, a narrativa justaposta de episódios autônomos decorre do desenrolar progressivo da ação e contribui para a manutenção da inalterabilidade de ânimo do narrador. Em discussão sobre o desenrolar progressivo da ação na epopeia Alfred Döblin observa que:

Na obra épica a ação avança aos poucos, por aglutinação. Esta é a justaposição épica. Ela se opõe ao desenvolvimento do drama, ao encadeamento, a partir de um ponto [...] $\mathrm{Na}$ grande obra épica, os personagens isolados, ou episódios individuais extraídos do conjunto, mantêm sua vida; ao passo que, no romance [...], com sua forte tensão se apaga. (DÖBLIN apud TODOROV, 2015, p. 52)

$\mathrm{Na}$ obra, Ubaldo, à maneira épica, a justaposição dos episódios e o desenrolar progressivo da ação têm esse papel de minar a tensão. Não se aguarda, na leitura de Viva o povo brasileiro, o desenrolar dos fatos, como seria comum à leitura de um romance: a apresentação de um panorama da história do povo brasileiro é mais relevante do que o desfecho final. A organização temporal dos episódios no último capítulo é bastante reveladora nesse aspecto. O capítulo é composto por duas seções: na primeira delas, a ação acontece em 1972; na seguinte, que encerra a obra, em 1939. Portanto, não há a criação de tensão, ela é constantemente minimizada pela antecipação dos acontecimentos.

A justaposição dos episódios, no entanto, também serve a outro propósito. Ubaldo cria já no primeiro capítulo um contraponto que se estenderá por todo o romance, ao mostrar lado a lado a cena da morte do alferes Brandão Galvão, herói de guerra involuntário, e a das artimanhas criadas por Perilo Ambrósio para se tornar herói de guerra. Em relação a essa estruturação, Cunha observa que:

A comparação entre essas duas representações da tradição cívico-patriota é um recurso de leitura quase compulsório, proposto estruturalmente pelo próprio texto. As similaridades e divergências entre essas cenas de heroísmo 
são férteis pontos de partida para a compreensão de Viva o povo brasileiro (CUNHA, 2007, p.3).

Assim, percebemos que a justaposição dos episódios, além de privilegiar a apresentação dos fatos narrados em detrimento do desfecho, como é típico em epopeias, tem caráter fortemente estruturante na obra. Ela propicia o desenvolvimento paralelo de dois eixos narrativos simétricos das linhagens da elite e do povo. Tal simetria, facilmente observável nas epopeias homéricas, aqui se dá ao nível do significado. Ubaldo evita, entretanto, que essa oposição simétrica que estrutura o romance se torne dicotômica, com a inclusão de uma ampla e diversa gama de personagens e situações. Assim, cumpre seu propósito de afirmação da multiplicidade de perspectivas para a identidade brasileira. Conforme Cunha observa:

A quantidade de personagens, a diversidade das situações narradas, a longa duração da ação do romance e, em especial, a mobilidade e variação dos procedimentos narrativos e de vozes mimetizadas pela narração são recursos necessários a uma configuração múltipla do povo brasileiro e da identidade nacional. Ao mesmo tempo atestam a impossibilidade de uma voz única, que hierarquize e legitime essa multiplicidade de um lugar neutro (CUNHA, 2007, p.3).

Desse modo, vemos que Ubaldo se reapropria de procedimentos estilísticos do épico, dando-lhes nova função. A justaposição de episódios autônomos, o desenrolar progressivo dos fatos e a simetria, que na epopeia clássica têm a função de possibilitar a construção de uma totalidade, garantem, por meio de sua reapropriação paródica, a afirmação da multiplicidade e da heterogeneidade no romance.

Outro descentramento notável do paradigma clássico realizado por Ubaldo diz respeito ao narrador. Ao contrário da épica clássica, na qual o narrador se caracteriza pela impassibilidade e pelo distanciamento, Viva o povo brasileiro apresenta uma multiplicidade de vozes e pontos de vista que corroboram a ideia de uma identidade nacional múltipla e não-monolítica defendida pelo escritor. Geraldo Carneiro afirma que o texto de Ubaldo prescinde da univocidade característica do épico clássico, apresentando uma natureza polifônica: “em Viva o povo brasileiro o narrador se oferece à leitura como um conjunto de vozes, de máscaras através das quais a narrativa se complexifica e propicia uma dupla leitura simultânea, como epopeia e paródia” (CARNEIRO, 2005, p.12). 
O foco narrativo muda diversas vezes ao longo da obra, obedecendo a alguns padrões. Cunha observa que quando a narrativa trata dos personagens que representam as elites, o narrador normalmente interfere pouco, praticamente introduzindo apenas o episódio. A narrativa fica a cargo das personagens, por meio de diálogos, monólogos e relatos que substituem a voz do narrador. Já quando enfoca as camadas mais populares e subalternas - personagens que giram em torno da alminha reencarnada - o narrador mostra-se mais ativo, enfatizando a variação de registros (CUNHA, 2007, p.5-6).

É preciso observar que o emprego do foco narrativo é um dos fatores que contribui, como bem observa Lucia Helena, para que a obra (assim como a discussão sobre a identidade nacional) resvale, em certas passagens, na oposição binária "brancos dominantes cruéis $\mathrm{x}$ negros dominados bondosos" (HELENA,1993, p.90). O personagem Patrício Macário é justamente o meio pelo qual essa dicotomia é amenizada. Filho de Amleto Ferreira, por conseguinte, membro da elite, o militar participa da Guerra do Paraguai e retorna como herói. Desde antes da guerra, já se evidenciam nele incômodos com a situação precária dos exércitos e o tratamento dispensado a eles. Após a experiência na guerra e o encontro com Maria da Fé, Macário cria nova consciência. É por meio do personagem que Ubaldo realiza a mais veemente afirmação da natureza ficcional da história. No trecho abaixo, Macário escreve seu livro de memórias, que trata dos acontecimentos da Guerra do Paraguai. Seu relato é muito discrepante da versão oficial:

A parte referente à Campanha do Paraguai, por ser diferente da mentiralhada oficial e dos relatos dos historiadores panegiriqueiros que eram regra geral, ia com certeza ser contestada palavra por palavra. E o mentiroso terminaria por ser ele (RIBEIRO, 2014, p.561).

De forma contrastante, alguns críticos afirmam que a mitificação de Maria da Fé reforça certo caráter essencialista na obra. De fato, a personagem talvez seja, entre os heróis apresentados por Ubaldo, a que mais se assemelha a um herói épico. Como salienta Bowra, o herói épico:

Difere dos outros homens no grau de seus poderes. Na maior parte dos poemas heroicos, estes são especificamente humanos, muito embora sejam realizados além das limitações da humanidade. [...] Ele causa admiração primeiramente por ter em abundância qualidades que outros homens têm em menor escala (BOWRA, 1952, p.91). 
Da Fé destaca-se dos demais personagens por sua coragem extrema, sua firmeza de caráter e conscientização, que lhe são legadas - epicamente - pela linhagem: ela é intrépida como a mãe, tem a sabedoria da avó Dadinha e é decidida como sua ancestral, caboca Vu (DALCASTAGNÉ, 2003, p.8). Tamanhos são seu magnetismo e poder que se cria uma mística em torno dela e surgem rumores de capacidades sobrenaturais: "não é certeza mas há quem afirme que Maria da Fé conversa com passarinhos e se entende perfeitamente com eles" (RIBEIRO, 2014, p.393). Sua fama se alastra e ganha vulto. Ela adquire, então, o status de lenda. De maneira semelhante ao que acontece com o herói épico Odisseu na Odisseia, várias versões de suas aventuras passam a ser contadas por rapsodos, como vemos no trecho a seguir, no qual o cego Filomeno Cabrito fala ao povo do Arraial de Santo Inácio:

Então, Maria da Fé - este é o nome da grande guerreira - partiu para o sertão com seus milicianos, porque ouviu dizer que no sertão havia muita gente revoltada disposta a combater contra a tirania. [...] Não se sabe por onde anda Maria da Fé, nem o que está fazendo agora. Mas se sabe que, como vem escrito no seu nome, ela continua acreditando que vai vencer, nem que não seja ela em pessoa, mas quem herde as ideias e a valentia dela, que ela acha que serão muitos. Como nasceu perto da Independência, já deve de estar velha, porque ninguém nunca conseguiu cortar a cabeça dela. E talvez nem velha nem esteja, porque sabe o povo que ela só faz aniversário de quatro em quatro anos, tendo nascido num dia 29 de fevereiro (RIBEIRO, 2014, p.511).

Para Cunha, apesar de assumir esse caráter mítico, a personagem Da Fé não é um índice de um essencialismo contra o qual Ubaldo se posiciona ao longo da obra, pois "através da personagem, a pluralidade étnica brasileira se articula, com rigor, às relações econômicas, aos conflitos de classe e ao traço comum e veemente que reúne e iguala a todas as personagens" (CUNHA, 2007, p.10).

Além disso, João Ubaldo usa um tom grandiloquente e solene, característico de epopeias, intercalando-o com comentários irônicos. Um bom exemplo dessa grandiloquência irônica está no uso extensivo que Ubaldo faz da técnica épica do catálogo. O catálogo, que consiste na acumulação enumerativa de elementos, é normalmente quando se deseja expressar algo em sua totalidade. Além disso, tinha nas epopeias a função de mostrar a competência do narrador. $O$ pesquisador francês Pierre Brunel afirma que o efeito de sentido que se tem quando se realiza o catálogo em uma epopeia é o de "enumerar o inumerável", transmitindo na verdade, “a impossibilidade de dizer tudo" (BRUNEL, 2003, p. 207). Assim, tem- 
se a impressão de que o discurso não dá conta da imensidão, conferindo grandiosidade e magnitude à matéria narrada. Ubaldo utiliza o recurso inúmeras vezes ao longo da obra, entre elas, ao falar dos brancos devorados pelo caboco Capiroba:

No primeiro ano comeu o almoxarife Nuno Teles Figueiredo e seu ajudante Baltazar Ribeiro, o padre Serafim da Távora Azevedo, S. J., o alabardeiro Bento Lopes Quinta, o moço de estrebaria Jerônimo Costa Peçanha, dois grumetes, quatro filhos novos e ouvidores da Sesmaria, uns agregados, um ou outro oficial espanhol por lá passando, nada de muito famoso. No segundo ano, roubou mais duas mulheres e comeu Jacob Ferreiro do Monte, cristão-novo, sempre lembrado por seu sabor exemplar da melhor galinha ali jamais provada; Gabriel da Piedade, O.S.B., que the rendeu irreprochável fiambre defumado, Luiz Ventura, Diogo Barros, Custódio Rangel da Veiga, Cosme Soares da Costa, Bartolomeu Cançado e Gregório Serrão Beleza, minhotos de carnes brancas nunca superadas, raramente falhando em escaldados [...] (RIBEIRO, 2014, p.59).

A enumeração dos indivíduos devorados por Capiroba - "comedor de gente e dessacralizador da moral das caravelas"30 - cumpre a função épica de tentar expressar uma totalidade, além de ressaltar sua indescritível fome. $\mathrm{O}$ fato de ser um catálogo de vítimas de canibalismo já é em si inusitado. Quando comentários de Capiroba sobre a qualidade e sabor das carnes são incluídos junto à enumeração, a ironia predomina.

O processo de modalização do gênero épico no romance adensa-se na primeira parte do capítulo 14, na qual Ubaldo nos oferece uma magistral cena de teomaquia, nos moldes da Ilíada, com todos os requisitos da mecânica épica propostos por C. M. Bowra (1952). Em um intenso diálogo intertextual, o escritor emula o estilo homérico com riqueza de detalhes. Os modos épicos, até aqui diluídos pelo romance, acentuam-se na descrição das batalhas vivenciadas por Zé Popó e seus companheiros no campo de Tuiuti, durante a Guerra do Paraguai. Como nas obras homéricas, a ação passa a se desenrolar em dois planos distintos, o divino e o humano. Porém, Ubaldo adapta o plano divino conferindo-lhe maior brasilidade, introduzindo a mitologia nagô-iorubá, com seus orixás e arquétipos. As mitologias grega e nagô-iorubá têm um modelo de virtude, grosso modo, bastante semelhante. Os deuses são parecidos com os humanos em suas emoções, são capazes de sentir paixão, raiva, ciúmes, desejo e alegria. Além disso, são

\footnotetext{
${ }^{30}$ (HELENA, 2007, p.90)
} 
entidades muito individualizadas e pessoais,que interferem na vida e nos assuntos dos mortais.

Segundo Cláudia Teixeira, a permanência de personagens da obra, como Zé Popó, garante a continuidade lógica com os capítulos anteriores, e o plano divino "inaugura-se como elemento que simultaneamente adiciona à narrativa um referencial literário e um contexto de ampliação"(TEIXEIRA, 2006, p.153). Esse contexto de ampliação é garantido, sobretudo, pelas diferenças na concepção de destino, nas mitologias grega e nagô-iorubá. De acordo com a helenista Maria Helena da Rocha Pereira:

O homem homérico depende em última análise do destino, da moira, que a tudo parece dominar. A palavra moira é um substantivo comum que aparece inúmeras vezes nos Poemas Homéricos. Significa parte ou lote, e deste sentido deve ter passado, por extensão, a designar aquilo que cabe a cada um em sorte na vida. O destino é fixo, inamovível e nem os próprios deuses podem alterá-lo (PEREIRA, 1987, p. 120-121).

O homem homérico desconhece o conceito de livre-arbítrio ao mesmo tempo em que carece de uma noção unitária da personalidade, pois "falta a noção de vontade que é posterior e, ipso facto, a de livre arbítrio, que só naquela pode originar-se" (PEREIRA, 1987, p. 114).

$\mathrm{Na}$ obra de Ubaldo, apesar da interferência direta dos deuses nos assuntos humanos, percebemos que o livre-arbítrio é parte da concepção de homem, muito embora ainda divida espaço com a noção de destino, como podemos observar no trecho a seguir que mostra a conversa entre Oxalá e Oxóssi. Oxóssi vai até Oxalá pedir sua intercessão para que Ogum, deus da guerra, aceite participar da Batalha do Tuiuti para defender seus filhos, o que seria de grande valia. Eis que Oxalá responde:

Bem sei o que tu sentes, pois que venho presenciando o teu denodo e a tua aflição, bem como a morte de nossos filhos mais valorosos, nesses campos chamados de Tuiuti. E tens razão quanto ao que posso fazer, porque de fato posso fazer muito pouco. Como tu mesmo disseste, essa guerra não é nossa, nem nos cabe intrometer-nos nela. Há muitas coisas que estão escritas, há muitas coisas que compete aos homens escrever por si mesmos, porque suas almas são livres e, se guerreiam, é porque escolheram a guerra (RIBEIRO, 2014, p.441, grifo nosso).

Assim, percebemos que a fala de Oxalá ao mesmo tempo em que aborda a ideia de destino, acrescenta-lhe a noção de livre arbítrio, tão cara às religiões de origem africana no Brasil. Amplia-se dessa forma a visão de homem presente na epopeia. 
Se a visão de homem muda, a apresentação dos orixás se dá, no entanto, de forma muito semelhante à que ocorre nos poemas homéricos, em especial na Ilíada. Os deuses nas epopeias interagem com os humanos principalmente de duas formas distintas: pelos meios comuns em que essa comunicação se efetua, como orações, sacrifícios, sonhos, epifanias e oráculos, e por meios que tornam os deuses ainda mais humanos, como relações parentais e sexuais. Os deuses, conforme argumenta Kearns:

[P]odem muito bem ser envolvidos na resolução de assuntos humanos sem necessariamente fazer uma aparição. Mas essas aparições são aparições são "um aspecto central e característico dos deuses homéricos tanto que eles são apresentados como personagens em certo sentido equipolentes aos humanos" (KEARNS, 2014, p.60).

Cabe-nos ressaltar que os deuses gregos, nas epopeias, podem fazer aparições e intervenções estando visíveis apenas para alguns humanos ou até mesmo para nenhum deles.

$\mathrm{Na}$ obra de Ubaldo, os orixás interferem no plano material de forma semelhante, com vistas a auxiliar seus filhos nas batalhas. Um bom exemplo disso é a ação de Oxóssi no livramento de seu filho Zé Popó da morte no campo de batalha. No trecho a seguir, Zé Popó acha que juntamente com seus companheiros brasileiros acaba de vencer uma batalha, rechaçando os paraguaios do Tuiuti e está prestes a celebrar quando um novo ataque começa:

Reconheceu [...] Joaquim Leso [...]. Ia abraçá-lo, mas mal tinha dado o primeiro passo no terreno resvaladiço, pareceu ter recebido um esbarrão, um empurrão forte, e escorregou, caindo com o joelho no chão. Procurou quem o teria empurrado, não achou ninguém suficientemente perto, voltou-se a tempo de ouvir um ronco terrível vindo do matagal e ver a cabeça de Joaquim Leso ser esmigalhada por um projétil que desconhecia. [...] Mas Oxalá, pai dos homens, vê as batalhas. Oxalá tudo vê. [...] Viu também quando Oxóssi dardejou para fora dos matos, visível somente para ele como um raio azulado, e empurrou Zé Popó para um lado, evitando que o obus o atingisse. Que queria Oxóssi, que fazia envolvido nessa batalha dos homens, em que muitos bons haveriam de morrer se estava escrito assim? (RIBEIRO, 2014, P.436).

Oxóssi intervém a favor de Zé Popó mantendo-se invisível para ele, não lhe revelando nada sobre sua presença no campo de batalha. Já outros orixás se comunicam com seus filhos por meio de epifanias, de revelações, o que acontece de maneira recorrente em Homero. No trecho a seguir, Ogum se dirige a seu filho José de Arimateia, que está prestes a perder o estandarte de sua companhia: 
José de Arimateia, mantém firme o estandarte intocável de tua terra, que agora te passo às mãos. Quem te fala é teu pai Ogum, senhor das batalhas, invencível no combate, cujo nome é a própria guerra! Não esqueci os meus fihlos e estou aqui para não deixar que pereçam nas mãos do cruel inimigo. É imensa a minha dor, porque demorei a chegar e não pude evitar que matassem um dos meus filhos mais valorosos, Matias Melo Bonfim, galardão de Amoreiras, onde florescem os mimos do céu e os passarinhos cantam mais. E pela mesma razão também é desmedida a minha fúria, que agora farei desabar sobre o inimigo. Estou a teu lado, vencerás! Ogum-ê! (RIBEIRO, 2014, p. 446).

A revelação epifânica da presença dos deuses entre os homens, como a que acabamos de ver, é um dos muitos procedimentos de extração homérica utilizados por Ubaldo nesta seção do capítulo 14. No trecho acima, ainda podemos observar mais um deles, o uso de epítetos. Os epítetos geralmente são constituídos por uma perífrase e não são arbitrários, visto que "sua presença ajuda a caracterizar o herói e a enfatizar alguma qualidade sua, que naquele momento tem relevância especial" (PEREIRA, 1987, p. 54). No entanto, percebemos que as expressões referentes a Ogum - "senhor das batalhas", invencível no combate", “ cujo nome é a própria guerra" -, a Matias Melo Bonfim - "galardão das Amoreiras" e à localidade de Amoreiras - "onde florescem os mimos do céu e os passarinhos cantam mais" - vem não só ressaltar a bravura e valor dos guerreiros e a beleza do lugar, elas também ajudam Ubaldo a acentuar o caráter épico da descrição da batalha, por remeter o leitor ao estilo do hipotexto homérico. Elas trazem em si a memória inevitável das epopeias homéricas para as quais são "um elemento fundamental, fixado por uma tradição de séculos” (JAEGER, 2013, p.68).

Já havíamos comentado sobre a grande plasticidade da linguagem empregada pelo escritor, porém, ressaltamos que, aqui, ele garante tal efeito valendo-se do mesmo expediente empregado por Homero, o uso de símiles. Muito frequentes na epopeia homérica, eles têm uma dupla função: ornamental, por embelezarem o discurso, e explicativa, por estabelecerem uma relação de analogia entre entes, objetos e ações de naturezas distintas. A partir da analogia estabelecida, há uma assimilação de uma das partes comparadas pela outra. (PINHO, 1995, p.499) Como podemos ver no seguinte trecho: "E logo como um redemoinho, como um cata-vento de aço, como vinte mil facões esfarinhando o ar, o grande Ogum [...] cercou seu filho Arimateia” (RIBEIRO, 2014, p. 447). Aqui, vemos que são conferidas a Ogum qualidades de movimento giratório, força e rapidez, numa construção que, além apresentar extrema plasticidade, permite ao 
leitor visualizar a forma como cercou Arimateia, protegendo-o contra seus inimigos.

Teixeira argumenta que há na obra de Ubaldo a formulação de motivos caros ao mundo homérico e que se universalizaram a partir da epopeia, tais como o motivo familiar da despedida do guerreiro, a súplica e o sonho inspirador. Bowra lista algumas dessas convenções no levantamento que faz da mecânica da narrativa épica. São motivos recorrentes que, à primeira vista, não têm grande importância na narrativa, mas ajudam a conferir solidez e epicidade à matéria narrada. $\mathrm{O}$ tema da despedida do guerreiro é retratado na passagem em que, antes de narrar a morte do sargento Matias Melo, o narrador descreve sua despedida da família. No trecho abaixo, Ogum está no campo de batalha e observa o sargento, que é seu filho:

Na sua frente, sobre um morrote verde, um grupo de soldados combatia em torno do estandarte [...] que era mantido no ar pelo sargento Matias Melo Bonfim, feito de Ogum desde os sete anos, um de seus filhos mais valorosos. [...] Deixara seus dois filhinhos, Matilde e Baltazar, sua mulher Maricota e sua roça de milho e feijão, deixara sua mãe viúva e sua criação, prometendo voltar assim que ganhasse a guerra. Beijara a filhinha Matilde e o filhinho Baltazar na beira do atracadouro, antes de embarcar com seu vistoso uniforme para lutar pelo Brasil, abraçara sua mulher Maricota e sua mãe viúva e partira com o mesmo sorriso orgulhoso que estampava agora portando o estandarte intocável da companhia insulana [...] Ogum se preparou para animá-lo e dar-lhe conforto, mas o chumbo fervente de uma bala inimiga mordeu o pescoço tenro do rapaz de Amoreiras [...] (RIBEIRO, 2014, p.446).

Bowra considera passagens que mostram despedidas, como essa, são de extrema importância para o desenvolvimento da narrativa épica. Para ele, em certo sentido, passagens como essa não são necessárias à historia mas, de forma expansiva e grandiloquente, "conferem um fechamento digno as aventuras que aconteceram até ali e possibilitam [...] ressaltar alguns pontos sobre o modo como heróis se comportam" (BOWRA, 1952, p.184). Assim, vemos que a cena citada acima apenas reforça o caráter heroico de Matias Melo, ressaltando suas qualidades como excelente combatente, bom pai, marido e filho exemplar.

Outro recurso comum à narrativa épica é descrição de sonhos, inspirados normalmente pelas divindades. Bowra salienta a importância de sonhos na narrativa épica demonstrando as inúmeras vantagens que sua inclusão ao desenvolvimento da história. Segundo ele, os sonhos "são importantes em si e apresentam incidentes diferentes daqueles da vida cotidiana, eles criam um senso 
de destino ou de assuntos que devem ser encarados; eles muitas vezes acontecem em momentos importantes e decidem o curso que a ação tomará" (BOWRA, 1952, p.291). Na obra de Ubaldo, o sonho mostra-se muito importante para que Ogum decida se envolver na Guerra do Paraguai. Ogum mostra-se magoado por não ter sido chamado de imediato por seus filhos e por Oxóssi para interceder nas batalhas, já que ele é o orixá da guerra ${ }^{31}$. Mandado por Oxalá para persuadir o orixá a proteger seus filhos, Exu por meio de um estratagema, se faz passar por Iansã e entra em seus sonhos:

Exu voou para a casa de Ogum e o encontrou dormindo. Então Exu, o que come de tudo, mensageiro perfeito, o que ri na escuridão, entrou em forma de sonho no sono de Ogum, rei do ferro, excelente no combate, cujo nome é a própria guerra. Mas não entrou como Exu, entrou transmutado na figura de Iansã, curvando os quadris arredondados apareceu diante dos olhos adormecidos de Ogum e lhe falou (RIBEIRO, 2014, p.442).

Com a ameaça feita por Iansã no sonho, de que não desejaria mais ter filhos com ele nem o acompanharia mais nas batalhas, Ogum decide ir à guerra e sua intercessão tem papel decisivo na vitória brasileira na Batalha de Tuiuti. Vemos, portanto, que o sonho tem um papel fundamental no rumo que o desenrolar dos fatos toma. Na obra de Ubaldo tem uma das funções que sugere Bowra, a de instilar medo e cuidado e incitar personagens a ação (BOWRA, 1952, p. 297).

O diálogo intertextual com obras do universo homérico propriamente dito não se restringe ao capítulo 14. Temos ainda alusões diretas a ele na primeira seção do capítulo 9, no qual Ubaldo retrata a espera da escrava Merinha por seu amado Budião, remetendo-nos ao mito da Odisseia. De modo semelhante à Penélope, Merinha recorda do amado e aguarda o retorno de Budião por aproximadamente dez anos:

Uma memória, ai dela, partilhada por tantas mulheres como ela. Mulheres de qualquer nação, mulheres fraturadas pelo tanto que se puxava delas, pelas vidas de seus homens tão fracos na fortaleza, tão necessitados junto a elas, mas tendo que ir, desaparecer em duas empresas e expedições de vida, podendo nunca mais voltar, podendo até esquecer delas, podendo vir a achalas feias em antigas, e elas mesmo chorando[...] não queriam que seus homens fossem de outro jeito, pois de outro jeito nnão os amariam. [...] Nove anos se passaram, talvez dez, certamente mil e mais cem, e Merinha sabia que seu semblante de Penélope não era só dela, era parte do mundo e da vida das mulheres, da vida das pretas cativas, sempre exiladas não importava onde estivessem, por que tinha de ser assim? (RIBEIRO, 2014, p. 281).

\footnotetext{
${ }^{31}$ Cabe-nos ressaltar que a ofensa de Ogum com a falta de obediência à hierarquia já é em si, um motivo épico.
} 
Poderíamos argumentar que Ubaldo busca uma noção não monolítica de nação e de identidade nacional, mas resvala no universalismo ao retratar a condição e o sentimento femininos de modo arquetípico ${ }^{32}$. No entanto, na mesma cena, ele introduz a personagem Martina, escrava que apresenta comportamento oposto ao de Merinha, evitando, assim, essencialismos na representação da identidade feminina.

É importante, ainda, lermos Viva o povo brasileiro como um romance épico sob a luz da definição de epopeia estabelecida por Florence Goyet e já discutida no capítulo 1. A pesquisadora francesa ressalta a natureza dinâmica do gênero, que em sua concepção, "realiza o relato de um passado coletivo, permitindo refletir sobre a história sem recorrer a conceitos fixos, por problematizar as situações e os valores políticos" (GOYET apud OLIVEIRA, 2008, p.2). Essa definição de epopeia mostra-se muito interessante para nossa discussão, se considerarmos que Viva o povo brasileiro foi publicado em 1984, época da redemocratização do Brasil, um momento histórico de transição em que o país redefiniu rumos a serem tomados politica e socialmente. Como observa Cunha:

A publicação de Viva o povo brasileiro na década de oitenta pode ser lida em sintonia com o esforço geral da sociedade para recuperar a autoestima e se reconciliar com o país, após vinte anos em que ser brasileiro dependeu menos do acaso do nascimento do que da capacidade de driblar ou de acatar a ordem unida do "ame-o ou deixe-o" - o slogan do nacionalismo autoritário dos governos militares. O empenho na reconstrução do vínculo com a brasilidade, entretanto, não pode preterir evidências como as flagradas por João Ubaldo. (CUNHA, 2007, p.12)

Logo, podemos afirmar que a retomada da epopeia por parte de João Ubaldo tem um papel primordial nesse processo de reflexão sobre o momento histórico vivido pelo Brasil de então. A partir da revisitação do gênero, Ubaldo lança seu olhar sobre o mito fundador brasileiro e expõe o caráter do povo, baseado em categorias monolíticas de nação, identidade nacional e história. A partir da inserção párodica de temas, procedimentos estilísticos e técnicas típicas da epopeia, o escritor instala e desconstrói mitos de heroísmo e grandeza, ideais esses de "consenso entre os discursos de vencedores e vencidos - que prometem um rosto harmônico e ufano do Brasil” (HELENA, 1993, p. 93). Assim, consegue

\footnotetext{
${ }^{32}$ No próximo capítulo, discutiremos as implicações de uma leitura feminista do épico clássico.
} 
discutir a questão da identidade brasileira fora de um âmbito essencialista e etnocêntrico.

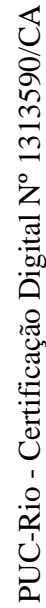




\section{5 \\ A odisseia de Penélope : o épico em negativo}

Deixem os gregos ser gregos e as mulheres aquilo que são.

Anne Bradstreet

Todos sabemos que há uma outra história a ser contada. Adrienne Rich

Em seu ensaio "A memória secreta da mulher", publicado em 2008, a escritora Nélida Piñon traça um breve inventário da memória feminina ao longo do tempo e se concentra inicialmente na figura da deusa grega Mnemósine. Juntamente com seu neto Orfeu e suas filhas, as Musas, a deusa proporciona o surgimento da epopeia - amálgama da memória histórica com o maravilhoso meio pelo qual os mortais na Antiguidade poderiam aspirar à notoriedade e glória post-mortem. No entanto, com o passar do tempo e a superação dos mitos, a deusa é esquecida, levando consigo a memória feminina, que passa a ficar confinada ao espaço doméstico e torna-se clandestina embora esteja viva nos textos literários escritos por homens. Conforme Piñon argumenta, os homens "ao se fazerem intérpretes únicos da memória coletiva, precisaram nutrir-se da malha das intrigas, dos diálogos amorosos, das confissões feitas nos leitos de morte, que só a carpideira, a amante, a mãe lhes poderia ditar" (PIÑON, 2008, p.133). Desse modo, vemos que, na concepção da escritora, a memória feminina ilumina e lança bases para as criações de grandes escritores e poetas como Homero, que dependem da "diligência narrativa, da perseverança descritiva da mulher, a fim de traduzir a alma humana, o mistério literário" (PIÑON, 2008, p.133). Numa postura de afirmação dos valores femininos, Piñon argumenta que tal influência por si só poderia justificar uma reivindicação feminina de coautoria desses textos.

Em outro ensaio da mesma coletânea, a escritora revela sua imensa admiração por Homero e seus personagens. Aqui, no entanto, não reivindica a coautoria de suas obras, à qual teria direito por ser mulher, mas, define-se como discípula do poeta grego:

Como escritora, sofro os dissabores da criação. Sinto-me diariamente perseguida por uma ancestralidade presente nos menores atos do cotidiano. $\mathrm{O}$ passado cobra-me a leitura constante dos livros sagrados. [...] Termino mais uma vez submissa às premissas de Homero, as urdiduras de suas histórias 
que constituem de certo modo um ato insolente. [...] Mas não faz falta que eu narre, para a literatura existir. É imprescindível porém que Homero me habite para eu criar. Um fato que me leva a reivindicar que a Odisseia pertence-me por usucapião. Toda épica homérica é de minha propriedade, sem lavrar o seu título em cartório público (PIÑON, 2008, p.360-361).

A escritora, assim, estabelece um relacionamento ambíguo em relação a Homero: ora afirma que poetas como ele são devedores da memória das mulheres, das quais ela é herdeira; ora, revela-se influenciada e submissa a ele. Esse relacionamento ambivalente em relação à tradição canônica é típico de escritoras feministas contemporâneas.

\section{1 Pressupostos feministas, escritura e cânone}

Boa parte da escrita/teoria feminista se notabiliza por desafiar e questionar ideologias patriarcais e noções tradicionais masculinas sobre a natureza daquilo que é classificado como feminino. Para tanto, essas mulheres têm como agenda política promover uma (re)leitura crítica dos textos canônicos da cultura ocidental, a fim de entender e revelar as injunções de gênero que os permeiam, com o intuito de resistirem a elas e promoverem sua desconstrução. Dadas a importância e a circulação desses textos, eles vêm informando por séculos a formação das identidades de gênero, mostrando-se invariavelmente opressivos para as mulheres, por conferirem a elas papéis de gênero que lhes negam a possibilidade de autonomia e empoderamento.

Desde os primórdios do movimento feminista, a prática de releituras de textos canônicos faz parte de sua agenda. A feminista norte-americana Adrienne Rich, no ensaio, "When We Dead Awaken: Writing as Re-Vision" ressalta que rever o passado e suas narrativas sob uma perspectiva inteiramente nova é vital tanto para o pensamento feminista como para sua sobrevivência. Apenas com uma crítica feminista de literatura seria possível desvendar as suposições sob as quais vivemos e construir um novo modo de autorrepresentação, mais autônomo em relação aos padrões patriarcais. Nas palavras de Rich, precisamos "conhecer as narrativas do passado, mas conhecê-las de uma maneira diferente daquela pela 
qual as conhecemos hoje; não para transmitir uma tradição, mas para romper com seu domínio sobre nós" (RICH, 1972, p.19).

Em "The Laugh of the Medusa", seu mais influente ensaio, Hélène Cixous corrobora a ideia defendida por Rich e acrescenta que as mulheres deveriam escrever sobre e para si mesmas, inscrevendo-se nos textos, no mundo e na história, por conseguinte. Essa seria uma forma de se posicionarem contra os padrões patriarcais excludentes, ressaltando seu caráter culturalmente construído. Para Cixous, a escrita, de forma muito extensa e repressora, é regulada por uma economia masculina ou seja "é um locus onde a repressão feminina tem sido perpetuada [...] e a mulher nunca tem sua vez de falar" (CIXOUS, 1976, p. 876). Assim, vemos que Cixous advoga uma escrita feminina a partir da qual a mulher possa deslocar o discurso masculino e apropriar-se dele, "para inventar uma linguagem na qual possa se inserir" (CIXOUS, 1976, p. 887).

Com o passar dos anos, outras percepções e reivindicações tomaram a agenda de escritoras feministas tais como uma concepção de identidade feminina múltipla e instável e a adoção de uma visão não binária de mundo. Linda Hutcheon, em The Politics of Postmodernism, ressalta essa multiplicidade de perspectivas, que não permitem que o movimento se apresente como unívoco e monolítico. Não há, portanto, um consenso cultural no que tange à questão de representação:

A história do pensamento feminista no que tange esta questão inclui o confronto das representações domintantes sobre a mulher como deturpadas, a restauração das autorrepresentações femininas do passado, a geração acurada de representações de mulheres e o reconhecimento da necessidade de se representar as diferenças entre as mulheres (de sexualidade, idade, raça, classe social, etnia, nacionalidade), incluindo suas diversas orientações políticas (HUTCHEON, 1995, p.141).

Hutcheon vai além e afirma que os feminismos têm provocado uma mudança nos sistemas de representação e conhecimento. Eles provocam reflexões sobre as questões do corpo e do desejo femininos, inserindo-os em discussões que os contemplam como social e historicamente construídos, pois

Estamos sempre lidando com sistemas de sentido operando dentro de certos códigos e convenções que são socialmente produzidos e históricamente condicionados. [...] Muitas teóricas feministas têm argumentado sobre na necessidade de desnaturalizar nosso entendimento baseado no senso-comum sobre o corpo na arte, a necessidade de revelar os mecanismos semióticos de posicionamento de gênero que produzem tanto a imagem corpórea quanto os 
desejos (masculinos e femininos) que eles evocam (HUTCHEON, 1995, p.144).

Assim, a prática da reescritura e da releitura do cânone decerto ocupa um lugar de destaque no pensamento e na prática feminista, porque promovem essa desnaturalização de que nos fala Hutcheon. Ela ainda aponta a prática da reescritura feminista como uma das mais radicais na literatura pós-moderna, principalmente por seu uso característico de diversas estratégias narrativas como a reapropriação paródica, o apagamento das fronteiras textuais, a carnavalização, a metaficção e a fragmentação narrativa. Além disso, uma de suas importantes contribuições é a revisão da história e das grandes narrativas que posicionam as mulheres como ex-cêntricas, ou seja, situam-nas no grupo daqueles indivíduos que estão fora de um centro, caracterizado como masculino, de origem europeia e heterossexual (HUTCHEON, 1991, p.65-66). Assim sendo, percebemos que as reescrituras feministas são também processos fundamentais para preencher vãos e revelar apagamentos e seleções promovidos pela história hegemônica e pelas grandes narrativas. De acordo com Chandra Talpade Mohanty, "a própria prática de reescrever leva à formação de uma identidade politizada e consciente" (MOHANTY, 2004, p.78).

Uma das escritoras contemporâneas praticantes desse tipo de releitura/reescritura é a canadense Margaret Atwood. A escritora se distingue pelo forte ativismo político e pela produção prolífica de romances, poemas e ensaios. No Brasil, temos apenas traduções de alguns seus romances: A mulher comestível (1969), Madame Oráculo (1976), O conto da aia (1985), Olho de Gato (1988), A noiva ladra (1993) Vulgo Grace (1996), O assassino cego (2000), Oryx e Crake (2003), A Odisseia de Penélope (2005) e $O$ ano do dilúvio (2013). Ganhou, nos anos 1980, destaque internacional, tendo recebido diversos prêmios literários, dentre eles o Booker Prize de 2000, por $O$ assassino cego, o Prêmio Arthur C. Clark, concedido a escritores de ficção científica, em 1987, e o Príncipe das Astúrias, na categoria Letras, em 2008. Na ocasião de entrega deste último, destacou-se a excelência de sua obra, "que explora diferentes gêneros com agudeza e ironia, porque nela assume inteligentemente a tradição clássica, defende a dignidade das mulheres e denuncia situações de injustiça social." Foi agraciada também com a mais alta distinção de seu país, a Ordem do Canadá, e incluída na calçada da fama do Canadá, no ano de 2001. 
Além da importante contribuição para o desenvolvimento da literatura canadense, Atwood teve um papel muito relevante para o estabelecimento de uma literatura feminina, por questionar não somente os estereótipos de gênero e nacionalidade, mas também por expor as "ficções culturais e os limites que elas impõem ao nosso entendimento de nós mesmos e do outro" (SINHA, 2008, p.87). Em recente entrevista concedida ao jornal britânico The Telegraph, a escritora declarou que sua visão feminista mudou ao longo do tempo e que considera feminismo uma conjunto de direitos humanos "porque eu penso radicalmente que mulheres são seres humanos e, portanto, elas se apresentam em uma variedade na qual outros seres humanos também se apresentam". Desse modo, Atwood se posiciona contra uma visão essencialista de mulher, admitindo múltiplas possibilidades. Ela acredita, portanto, que não há um 'ponto de vista feminino', estático, simples, único, e sim possibilidades plurais de olhar feminino.

\section{2}

\section{A odisseia de Pénelope: releitura do mito e subversão paródica de procecimentos estilísticos da epopeia}

Em A odisseia de Penélope, obra publicada em 2005, Atwood se volta inteiramente para as questões do feminino em sua pluralidade ao reescrever parodicamente a Odisseia, de Homero, promovendo a subversão do épico tanto em seu aspecto formal quanto em sua temática mítica. A principal subversão da matriz clássica executada pela escritora - da qual muitas outras são decorrentes - é conferir o papel de narradora à personagem Penélope e às aias assassinadas por Odisseu. De acordo com Paul Innes:

Ao reescrever a história de Odisseu para colocar Penélope no centro do romance, Atwood torna clara a influência resistente e duradoura das grandes narrativas, marcadas por questões de gênero e pela adoção de gêneros textuais, bem como pela necessidade de reagir contra elas, trabalhá-las novamente e reinterpretá-las (INNES, 2013, p.21).

Entre as grandes narrativas a que Innes se refere está o clássico, ao qual sempre retornamos, segundo Kermode (1983), por métodos de recriação. Em sua recriação desconstrucionista do texto de Homero, Atwood não visa invalidá-lo 
nem estabelecer um significado definitivo para ele ou sequer substitui-lo; afinal, como observa Ítalo Calvino, "um clássico é um livro que nunca terminou de dizer aquilo que tinha para dizer" (CALVINO, 2007, p.11). Ela apenas deseja com sua obra desafiar uma grande narrativa, que reprime ou suprime a mulher. Como qualquer outra releitura feminista, a obra de Atwood é construida para "coexistir e argumentar com outras leituras, e, até mesmo, tomar emprestado alguns de seus pressupostos" (MILLER, 1990, p.6) e estabelecer com ele uma relação ambivalente.

A recriação da Odisseia efetuada por Atwood é antes de tudo de natureza paródica e centra-se em dois pontos primordiais: a desconstrução do mito presente na epopeia homerica e a modalização do gênero épico a partir da reapropriação e subversão de seus expedientes. Em um processo paródico muito comum na ficção feminista contemporânea, a reapropriação dos expedientes épicos ocorre num duplo processo de instalação e ironização. Ao mesmo tempo em que estão inseridos na narrativa, esses expedientes têm seu status questionado. Na visão de Linda Hutcheon, "a paródia sinaliza como as representações do presente advêm das do passado e quais consequências ideológicas derivam da continuidade e da diferença" (HUTCHEON, 1995, p.93).

Atwood incorpora as determinações temáticas e formais relativamente constantes do épico a uma novela, forma que problematiza ainda mais esse processo, por razões que discutiremos a seguir. A novela, em sua inegável semelhança com o romance, poderia fazer-nos crer, a princípio, que esse processo se instauraria seguindo basicamente as mesmas injunções que vimos em Viva o povo brasileiro. Ou ainda, talvez, que poderia nos fazer supor que estivesse facilitado pelo fato de Atwood - à diferença de Ubaldo - se dedicar a um diálogo apenas com a Odisseia, a epopeia homérica mais próxima do romance e de seu prosaísmo.

De fato, apesar de não lhe faltarem traços do maravilhoso, a Odisseia conta com uma infinidade de cenas domésticas e se dirige a um aspecto mais humano da vida dos heróis. A introdução desses elementos domésticos na obra não pertence à tradição dos velhos cantos heroicos, mas advêm da demanda de um momento mais contemplativo e afeito à paz. Como observa o helenista Werner Jaeger

O fato de a Odisseia observar e representar no seu conjunto uma classe, a dos nobres senhores, com seus palácios e casario, representa um processo na 
observação artística da vida e de seus problemas. A epopeia torna-se romance. Se a periferia da imagem de mundo da Odisseia nos arrasta para a fantasia aventureira dos poetas, para as sagas heroicas e mesmo para o mundo do fabuloso e do maravilhoso, é com tanto maior força que sua descrição que sua descrição das relações familiares nos aproxima da realidade (JAEGER, 2013, p.41, grifo nosso).

Ainda, de forma semelhante ao romance, a epopeia é reconhecida por sua extensão e amplitude. Hainsworth observa que : "a expansividade é parte da fundação da épica, pois ela é [...] escrita de forma grandiosa, seu calibre estendido e seus insights aprofundados" (HAINSWORTH, 1991, p.7). Assim, o calibre estendido é por vezes obtido tanto na epopeia quanto no romance a partir da inclusão de episódios dipersivos e autônomos. Tais episódios, em especial, são abundantes na Odisseia, na qual "se inseriu uma complexa tessitura de variantes e de histórias verdadeiramente autônomas; invenções premeditadas e improvisadas em estilo épico" (BURKERT, 2001, p.40).

Já a novela literária, ao contrário, se notabiliza por sua dimensão exígua, impedindo a inclusão de epispódios dispersivos, sendo geralmente definida como um relato ficcional de dimensão média. Segundo Olegário Paz e António Moniz, a novela é:

Além da dimensão, outras características são específicas da novela: uma intriga menos complexa do que o romance; uma estratégia narrativa e discursiva mais directa, com poucos ou nenhuns episódios dispersivos e autónomos (encaixe); maior vivacidade rítmica e sintáctica (mais elipses, menos cenas); menos estudo psicológico das personagens, intenção mais explícita do autor (PAZ \& MONIZ,1997, p.350, grifo nosso).

Percebemos, pois, que a novela mostra-se mais linear e acelerada que o romance e a epopeia. Essa definição é corroborada por Angélica Soares que acrescenta que "por esse sentido de economia unilinear, faz-se predominar a ação sobre as análises e as descrições e são selecionados momentos de crise, aqueles que impulsionam rapidamente a diegese para o final" (SOARES, 2006, p.55).

Desse modo, se compararmos as definições de novela à caracterização tradicional da epopeia, com sua narrativa repleta de episódios dipersivos e autônomos, a incompatibilidade de propósitos dos dois gêneros salta aos olhos. Portanto, para efetuar a modalização épica da novela, Atwood exclui de sua obra a maioria dos episódios constitutivos do poema homérico, que narravam sobretudo acerca das errâncias de Odisseu. Ao dar o controle da narrativa a Penélope, a escritora enfatiza ainda mais essa esfera doméstica e de intimidade, limitando os 
acontecimentos narrados em sua história àqueles que foram vivenciados pela personagem, reduzindo consideravelmente o relato de aventuras na obra. Invertese, assim, em A Odisseia de Penélope, o viés pelo qual o mito é desenvolvido em Homero: temos aqui a recapitulação de uma longa espera por um marido no confinamento de um palácio, cujo escopo aproxima-se do universo da novela, conforme definida por Paz e Moniz (1997) e Soares (2006).

Porém, se a exclusão dos relatos das aventuras de Odisseu, decorrente da exploração apenas da experiência de Penélope, permite uma forma mais enxuta como a novela, Atwood, por outro lado, não põe fim aos episódios autônomos. As aias também ganham voz e narram dez capítulos, rompendo com a unilinearidade típica da novela. Em outras palavras, ao mesmo tempo em que modaliza o gênero épico e subverte suas convenções, Atwood realiza o mesmo processo com o gênero da novela.

Em A odisseia de Penélope, a releitura feminista do mito que informa a Odisseia vai além do recorte estabelecido no texto homérico. No prólogo, Atwood revela que precisou recorrer a um material diferente da Odisseia, principalmente para obter informações sobre a família de Penélope, sua vida de solteira e as circunstâncias de seu noivado. De fato, na cultura ocidental, as narrativas envolvendo o mito de Penélope antes do casamento são escassas. A personagem é mais conhecida por seu papel de esposa de Odisseu, funcionando como um "comentário sobre o dilema da esposa deixada em casa, sobre a precariedade de sua virtude" (FELSON \& SLATKIN, 2004, p.111). O mito funciona ainda como contraponto edificante a outras representações femininas em poemas homéricos, tais como Helena e Clitemnestra, adúlteras ou iludidas pelos deuses. Penélope, assim, consubstancia-se como epítome da fidelidade e virtude femininas. Em discussão sobre a importância pedagógica da épica, Jaeger analisa os elementos femininos na velha cultura aristocrática propagada pelos poemas homéricos e afirma que :

A areté própria da mulher é a formosura. Isso é tão evidente como a valorização do homem pelos seus méritos corporais e espirituais. [...] A mulher todavia não surge apenas como objeto da solicitação erótica do homem [...] mas também na sua firme posição social e jurídica de dona da casa.[...] Penélope, desamparada e desvalida, move-se entre o tropel dos atrevidos pretendentes com uma segurança que revela sua convicção de que será tratada como o respeito devido à sua pessoa e à sua condição de mulher. A cortesia com que os senhores tratam as mulheres de sua condição é fruto de uma cultura antiga e de uma elevada educação social. A mulher é atendida 
e honrada não só como um ser útil [...] mas acima de tudo e principalmente porque, numa raça orgulhosa de cavaleiros, a mulher pode ser mãe de uma geração ilustre. Ela é mantenedora e guardiã dos mais altos costumes e tradições (JAEGER, 2013, p. 45, grifos nossos).

Além desse papel descrito por Jaeger (2013), nas epopeias clássicas, os papéis reservados às mulheres envolvem basicamente causar conflitos ou sofrer por eles, fazer mediação entre guerreiros e demonstrar o luto pelos heróis. Ao conferir a personagens femininas o controle da narrativa, a escritora também instaura uma nova desconstrução/atualização no paradigma épico clássico, no qual "as histórias são concebidas, via de regra, por um ponto de vista masculino" (GRIFFIN, 2010, p. 20) e narram sobre feitos de homens ${ }^{33}$.

A helenista Helene P. Foley (2005, p.118) observa que, no que concerne às questões de gênero na epopeia clássica, épicos que retratam longas viagens heroicas tendem a ser menos regulados pelas realidades históricas e são mais experimentais, por conta disso, no tratamento e distribuição dos papéis de gênero. Diferentemente da Ilíada, a Odisseia é repleta de personagens femininas marcantes. Nela, temos falas reservadas a diversas personagens femininas, até mesmo àquelas não pertencentes à aristocracia, como Euricleia e Melanto. Entretanto, todas as personagens são reguladas por um sistema claramente patriarcal: apesar de falarem, elas raramente narram suas próprias histórias e quando falam, segundo Foley, "falam a partir das margens da comunidade masculina" (FOLEY, 2005, 105).

Por meio da paródia à Odisseia, Atwood dá voz às mulheres silenciadas e subverte o arquétipo mítico de Penélope, como esposa fiel e cordata, presente na obra de Homero. Ela faz parte do grupo de artistas e críticos "interessados em pensar a questão de gênero tanto historicamente quanto em suas configurações contemporâneas" (SLATKIN et FELSON, 2004, p.113), evidenciando o impacto que os estudos de gênero tiveram sobre nossas leituras do épico.

Da mesma forma que os papéis de Penélope e das aias são reconfigurados na obra de Atwood, a imagem de Odisseu como herói arquetípico também o é. Propagada primordialmente pela Odisseia, na qual são ressaltadas suas múltiplas qualidades, Odisseu caracteriza-se por ser um herói polýmetis, cheio de malícia e

\footnotetext{
${ }^{33}$ Basta nos atermos às proposições da Ilíada, da Odisseia e da Eneida para vermos que os eventos na narrativa girarão em torno de personagens masculinos, suas ações e percepções.
} 
de habilidade e polýtropos, um solerte e linguarudo em grau superlativo ${ }^{34}$ (BRANDÃO, 1999, p.291). Assim sendo, é um herói bastante peculiar dentro do universo épico, pois se notabiliza mais por sua inteligência do que por sua força. Todos os embates e enrascadas em que se envolve são ultapassados e vencidos com base na sua destreza verbal e na sua incrível capacidade de criar ardis. Odisseu nos é retratado na Odisseia "em todo tipo de ambiente imaginável, em casa e longe dela, natural e sobrenatural, enobrecedor e degradante, físico e intelectual, desesperado, humorístico, romântico e de labuta diária" (SILK, 2014, p.42), dos quais sai sempre mais sábio.

Em A Odisseia de Penélope, essa imagem de homem malicioso, criador de muitos ardis persiste. No entanto, essa imagem é desconstruída por meio da ironia e do tom humorístico do texto, reduzindo-o a um homem quase comum. As experiências por ele vivenciadas e que lhe garantem traços de herói na Odisseia são consideradas casos inventados por ele. Odisseu não é louvado por sua linhagem nem por seus feitos sobre-humanos, cuja veracidade é questionada. No trecho abaixo, no qual o herói é apresentado na disputa pela mão de Penélope, as aias o observam e uma delas comenta:

Aquele é Odisseu, coitado'. disse uma das moças. Ele não era considerado candidato sério à minha mão, pelas escravas. O palácio de seu pai situava-se em Ítaca, um rochedo onde só havia cabras. Suas roupas rústicas combinavam com seus modos de príncipe interiorano, e ele já havia exposto diversas ideias complicadas que os outros consideravam peculiares. Era astucioso, porém, diziam. Na verdade ser esperto demais era sua desgraça. Os mais jovens zombavam dele : 'Não jogue com Odisseu, filho de Hermes', diziam. 'é impossível ganhar'. Isso equivalia a afirmar que ele era trapaceiro $e$ ladrão. Seu avô Autólico ficou conhecido por essas características, sua reputação era de nunca ter ganho nada honestamente na sua vida. (ATWOOD, 2006, p.38, grifo nosso).

Assim, as aias enfatizam o lado negativo das características heroicas de Odisseu, ironizando-as, além de ressaltarem a singeleza de seu reino e a inadequação de suas maneiras em comparação com os demais pretendentes. Nessa mesma cena, ocorre algo bastante interessante, Odisseu torna-se objeto aos olhos de Penélope e das aias, numa inversão daquilo que chamamos de male gaze. A teórica norte-americana Laura Mulvey, ao discutir sobre o termo em artigo, observa que "em um mundo ordenando pelo desequilíbrio sexual, o prazer em olhar sempre foi dividido entre masculino/ativo e feminino/passivo"(MULVEY,

\footnotetext{
34 Donaldo Schuller apresenta como tradução para o termo polýtropos "o multifacetado"
} (SCHÜLER, 2007, p.13) 
1999, p.809). O olhar masculino se projeta sobre a figura feminina e a estiliza de acordo com sua fantasia. Na trecho abaixo, vemos que Atwood inverte essa lógica: quando ao perguntar se Odisseu seria bom em corridas, ouve piadas de cunho sexual das aias, tecendo comentários sobre seu tórax avantajado e suas pernas curtas. Alvo de chacotas por sua inexperiência, Penélope recebe a seguinte resposta de sua prima Helena:

"Ela e Odisseu formam um par perfeito. Os dois têm pernas curtas". [...] As escravas riram baixinho. Eu não achava que minhas pernas eram tão curtas assim, e certamente não imaginara que Helena houvesse reparado nisso. Mas quase nada lhe escapava quando se tratava de inventariar os dotes e os defeitos físicos alheios (ATWOOD, 2006, p.39-40).

No trecho acima, Helena e as aias fazem comentários jocosos sobre o corpo de Odisseu, assumindo um papel ativo no prazer em olhar. Atwood instala e subverte os modos de representação e convenções que informam o gênero épico, principalmente a masculinidade do olhar, e desnaturaliza a representação das mulheres que nos é mostrada na Odisseia, indo ao encontro do que Hutcheon classifica como uma tentativa de "desdoxificar qualquer noção de desejo como simplesmente preenchimento individual, de alguma forma independente dos prazeres criados pela cultura e dentro dela" (HUTCHEON, 1995, p.144).

É importante também considerar o fato de que, ao posicionar Penélope como narradora homodiegética, isto é, participante dos fatos que narra, Atwood também rompe com o paradigma épico de apresentação objetiva dos fatos, engendrando um processo subjetivo-perspectivista que é totalmente estranho ao texto homérico, conhecedor apenas "de um presente uniformemente iluminado, uniformemente objetivo" (AUERBACH, 2007, p. 5). O narrador só interfere nos eventos, posicionando-se em primeira pessoa, quando há um evento diegético relevante, o que é raro. Na obra de Atwood, contudo, a protagonista/narradora está íntima e ativamente envolvida nos acontecimentos. Penélope relembra o passado, critica a versão do mito narrada na Odisseia, que atribui ao marido, oferecendo sua versão:

Agora que todos os outros perderam o fôlego, é a minha vez de fazer o relato. Devo isso a mim mesma. Tive de me esforçar para contar o caso: contar histórias é uma arte menor. Coisa para velhas, andarilhos, rapsodos cegos, criadas, crianças - gente com tempo a perder. Antigamente as pessoas ririam se eu bancasse o menestrel - não há nada mais ridículo do que uma aristocrata que se mete a artista - mas a essa altura não me importo mais com a opinião pública.. Portanto, vou tecer minha própria narrativa (ATWOOD, 2006, p.17). 
De acordo com Staiger, "o autor épico não se afunda no passado, recordando-o como o lírico, e sim rememoriza-o. E nessa memória fica conservado o afastamento temporal e espacial" (STAIGER, 1974, p.79). Em Atwood, a narrativa da personagem Penélope envolve desde sua vida doméstica até seus percalços durante a ausência de Odisseu. Os fatos são por ela recordados e seu relato oscila, de acordo com seu ânimo e suas emoções ao longo da narrativa. Atwood subverte, assim, a caracterização homérica, revelando o íntimo de Penélope, tão inescrutável ao leitor na obra clássica. Os fatos são por ela recordados ${ }^{35}$, isto é, trazidos de volta ao seu coração, se levarmos em consideração a origem etimológica da palavra, revelando uma maior aproximação entre sujeito narrador e objeto narrado. No trecho a seguir, Penélope narra as circunstâncias de seu casamento com Odisseu. Nele, podemos perceber tal quebra do tradicional distanciamento épico: "Era como se eu não estivesse lá. E era dia do meu casamento. Foi demais para meus nervos. Comecei a chorar como faria com tanta frequência no futuro e me levaram para descansar um pouco em minha cama" (ATWOOD, 2006, p.41).

A recapitulação que Penélope faz de seu passado acaba por relativizá-lo - ao contrário do que ocorre com o passado na matriz clássica - uma vez que aborda também as consequências dele nos dias de hoje. Diretamente do Hades, local onde está há mais de três mil anos, a esposa de Odisseu intercala seu relato com inúmeras referências ao tempo presente, compara-o ao passado mítico e estabelece relações entre eles constantemente, ao longo da narrativa. Não há aqui uma separação rigorosa entre o tempo mítico (in illo tempore) e o tempo presente, fazendo, mais uma vez, com que o distanciamento em relação ao objeto narrado diminua, como podemos notar no relato de Penélope sobre sua experiência no Campo de Asfódelos, local do Hades para onde as almas iam enquanto esperavam julgamento:

Após centenas de anos, milhares talvez - é difícil contar o tempo aqui, pois não temos nada que se pareça com ele -, os costumes mudaram. Os vivos não vinham muito ao mundo subterrâneo, e nosso refúgio foi suplantado por outro vizinho muito mais espetacular - poços em chamas, gritos e dentes rangendo, vermes monstruosos, demônios com tridentes - e muitos efeitos especiais. [...] Eu me interessei muito pela invenção da lâmpada elétrica, por exemplo, e pelas teorias de energia e da matéria do século XX. Mais recentemente alguns de nós conseguiram se infiltrar no novo sistema de

35 Cf. CUNHA, Helena Parente. "Os Gêneros Literários". In: PORTELA, Eduardo. Teoria Literária. Rio de Janeiro: Tempo Brasileiro, 1999. 
comunicação que envolve o mundo inteiro, e viajar por ele, vendo o mundo através de telas iluminadas, que servem de altares domésticos. (ATWOOD, 2006, p.33).

Vemos aqui que seu foco é muito diferente da versão clássica de Homero: o mito ganha contornos dramáticos - há uso extensivo do monólogo dramático muitas vezes cômicos, perdendo-se, assim, o tom solene e grandiloquente, típico das narrativas épicas. Além disso, não há no texto de Atwood uma "alta quota de episódios espetaculares, batalhas sangrentas, exaltação de heróis sobre-humanos em luta contra a fortuna, enfim [..] um arsenal de grandiosidade" (CUNHA, 1979, p.109). Temos sim, fatos comezinhos em profusão, situados na esfera do lar.

Norma Felson e Laura Slatkin (2004) discutem a importância do lar, na Odisseia, que consideram um poema de recuperação, estruturado sobre duas categorias, o oikos (o lar) e o nóstos (o desejo de regressar). No poema, Homero fala de um vazio de poder em Ítaca e dos problemas daí advindos. Na longa ausência do marido, Penélope torna-se responsável pela preservação e integridade do oikos, para onde seu marido anseia por retornar. Tudo depende daquilo que a personagem faz e do tipo de esposa que ela se torna. (FELSON \& SLATKIN, 2004, p.107). Apesar de ser uma aristocrata e exercer algum poder, Penélope é confinada ao âmbito do lar como qualquer outra mulher. Portanto, é natural que na releitura de Atwood maior prominência fosse dada à esfera doméstica e a toda uma sorte de elementos a ela relacionada, conferindo ao texto um aspecto intimista. Segundo Coral Ann Howells, em A odisseia de Penélope, "a narrativa de Penélope, apesar de conversacional e cativante, nos diz mais do que detalhes realistas de sua vida cotidiana, pois essa é sua história de resistência às narrativas que lhe foram impostas" (HOWELLS, 2006, p.11).

A narrativa da personagem estabelece a todo momento um questionamento e subversão ao texto homérico. A principal delas se dá em relação à imagem de si como modelo de esposa, que é questionada por ela mesma na paródia de Atwood:

Eu não havia sido fiel? Não havia esperado, e esperado e esperado, apesar da tentação - quase uma compulsão - de fazer o contrário? E o que me tornei? Uma lenda edificante. Um chicote para fustigar as mulheres. [...] Não sigam meu exemplo (ATWOOD, 2006, p.2).

Assim, vemos que Atwood ironiza o status de exemplo edificante conferido a Penélope na cultura ocidental. 
Ainda em seu prólogo, Atwood ainda afirma que sempre se sentiu assombrada pelas inconsistências existentes na Odisseia, principalmente no que diz respeito a Penélope e às doze escravas enforcadas quando da chegada de Ulisses a Ítaca. $\mathrm{Na}$ epopeia de Homero, é dado pouco destaque a seu enforcamento, apenas alguns poucos versos no canto XXII, que Atwood utiliza como epígrafe, juntamente com um elogio feito à virtuosa esposa de Odisseu. Tal justaposição tem como efeito fazer com que o leitor reflita sobre os papeis opressivos a que são relegadas as personagens femininas na trama de Homero, em especial a Penélope e às aias, assassinadas sem chance de explicação.

A escritora dá voz às escravas em capítulos que se intercalam à narração de Penélope, em uma intervenção semelhante à do coro nas tragédias gregas. Em suas notas explicativas à edição de 2005, Atwood revela que o coro das escravas é uma homenagem aos Coros da tragédia grega, cuja função era descrever e comentar sobre a ação principal, por meio de música, dança e recitação. Dessa maneira, vemos uma mistura de tradições poéticas diferentes - a trágica e a épica. O coro, na obra, se manifesta por meio de diversos gêneros textuais - clássicos ou contemporâneos - tais como canções folclóricas, baladas, uma pequena peça de teatro, uma palestra de antropologia, e até mesmo registros de um julgamento.

Tal mistura de gêneros - bem como o uso extensivo de paratextos, já mencionados anteriormente - rompem com o processo linear de leitura. Hutcheon (1991) afirma que tais traços são típicos da ficção feminista pós-moderna, pois "inpedem qualquer tendência por parte do leitor a universalizar ou eternizar" padrões de representação (HUTCHEON, 1991, p.302). Assim, em A odisseia de Penélope, Atwood, ao fazer uso de paratextos, contesta o impulso totalizante presente na obra de Homero, tida aqui como uma grande narrativa. Na visão da crítica Sigrid Renaux, as intervenções do coro "desconstroem o estilo épico ao fragmentá-lo em uma série de gêneros menores da época e também da atualidade, tornando-o híbrido, caracterizando ao mesmo tempo uma voz feminina que se contrapõe à voz patriarcal da épica homérica" (RENAUX, 2009, p. 140).

No trecho a seguir, extraído do capítulo 8 ("Se eu fosse princesa, uma canção popular"), em que as escravas comentam e até mesmo zombam do descontentamento inicial de Penélope com o casamento:

Se eu fosse princesa, cheia de prata e ouro/ Amada por um herói, jamais envelheceria;/ Ou, se um jovem formoso me desposasse, / Linda, feliz e livre, 
eu sempre seria. / Siga então senhora, por longas vagas, / Sobre a água fria feito tua cova escura/ Que engolirá talvez teu barco azulado/ Pois à tona nos mantém só a nossa fé mais pura. (ATWOOD, 2006, p.52)

Em seu posfácio, Atwood afirma que "a convenção de zombar da ação principal já estava presente nas peças satíricas, representadas com as tragédias sérias" (OP, 2006, p. 158). As escravas comentam os relatos de Penélope, ironizando-os ao mesmo tempo em que dão seu ponto de vista acerca deles. Como já dito anteriormente, os capítulos narrados por Penélope são intercalados pelo coro, numa organização que parodiza a simetria épica de concepção dos episódios. Ora temos a versão de Penélope, ora a zombaria das aias, que, juntas, formam um panorama da visão feminina sobre a Odisseia. Tal procedimento estilístico da épica é, no entanto, instalado apenas para ser minado, uma vez que a partir dele se introduzem vozes dissonantes que estão longe de proporcionar ao leitor uma visão totalizante e fechada dos fatos, típica dos textos homéricos. Ao contrário, a interpolação das diferentes versões serve para promover o questionamento do status simbólico da virtude feminina conferido à Penélope, tão presente e influente na cultura ocidental. Numa encenação intitulada "Os perigos de Penélope, um drama", as aias confrontam a versão de sua senhora, que alega ter permanecido fiel a Odisseu. Na dramatização, Penélope pede à serviçal Euricleia que encontre um jeito de eliminar as escravas antes que notícias de traições suas cheguem aos ouvidos do esposo, que acaba de aportar em Ítaca:

Penélope: E agora, cara ama, a banha está no fogo - / Ele me matará por satisfazer meu desejo/ Enquanto ele se divertia com ninfas e beldades, / Pensava que eu não faria nada além do dever? / Enquanto ele satisfazia as moças e deusas à vontade,/ Imaginava que eu ia secar quieta, feito uma passa?

Euricléia: Enquanto você alegava tecer uma mortalha/ Na verdade, divertiase na cama! E agora temos motivo para cortar sua cabeça! (ATWOOD, 2006, p.121)

Penélope fica nervosa e tenta angariar a conivência da criada, pedindo que ela não revele nada em nome de manter a honra de Odisseu intacta. Para tanto, percebe que terá que fazer com que elas caiam em desgraça para que sejam assassinadas pelo senhor:

Penélope: [...] Acuse as escravas de libertinas e desleais/ Apanhadas pelos pretendentes como indevidas presas, conspurcadas, vergonhosas, inadequadas/ Para servir a um senhor magnífico como ele! 
Euricléia: Vamos calar-lhes as bocas, mandá-las ao Hades - / Ele as tratará como vigaristas que são!

Penélope: E eu manterei minha fama de esposa honesta - / Todos os maridos olharão para ele, o bem-sucedido! / Mas vá logo - os pretendentes vão chegar para fazer a corte/ E eu preciso estar pronta para recebê-los. (ATWOOD, 2006, p. 122-123)

O leitor é, então, envolvido em um jogo textual e não consegue, saber de fato o que aconteceu, uma vez que a narrativa de Penélope contrasta com a das aias. Na visão de Howells, elas

assombram sua narrativa do começo ao fim. Culpam-na por suas mortes e a acusam de infidelidades repetidas com os pretendentes, sempre insistindo que ela foi conivente com seu enforcamento porque sabiam muito. [...] Elas não irão embora e se recusam a ser silenciadas. Transformam a Odisseia de Penélope numa narrativa polifônica na qual vozes dissidentes se contrapõem à pretensa autenticidade da confissão de Penélope. (HOWELLS, 2006, p.12).

Dois aspectos interessantes que precisam ser observados nos cantos das aias são a visão não monolítica de mulher que eles engendram e a subversão do círculo de personagens atuantes consagrada na narrativa épica clássica. Na novela de Atwood, "não há uma definição essencialista de 'mulher' [...] mas, em vez disso, representações de uma complexidade sem fim" (SINHA, 2008, p. 88). Esse fato fica evidente quando cotejamos os capítulos 3 e 4, quando Penélope e as aias fazem relatos sobre suas infâncias, respectivamente. Enquanto a aristocrata narra um eventual maltrato do pai em uma infância bastante protegida, cercada de luxo e conforto, as aias nos revelam a vida miserável que sempre levaram, mostrando-nos perspectivas femininas díspares. Esse aspecto relativo à questão de classe é obliterado por toda a épica clássica, dado que é observado por Auerbach:

A vida nos poemas homéricos só se desenvolve na classe senhorial - tudo o que porventura viva além dela só participa de modo serviçal. A classe senhorial ainda é tão patriarcal, tão familiarizada com as atividades quotidianas da vida econômica, que às vezes chega a esquecer de seu caráter de classe. Só que ainda é inconfundivelmente uma espécie de aristocracia feudal, cujos homens dividem a vida entre luta e caça, as deliberações no mercado e os festins, enquanto as mulheres vigiam as criadas em casa. Como estrutura social, este mundo é totalmente imóvel; as lutas só ocorrem entre diferentes grupos das classes senhoriais; de baixo, nada surge (AUERBACH, 2007, p.18).

Assim vemos que os cantos das aias têm um papel importante na obra de Atwood, pois promovem não somente a desconstrução da narrativa épica e da imagem de esposa virtuosa de Penélope, mas também nos fazem atentar para os 
vieses de gênero e de classe social presentes nos modos canônicos de representação. Eles os desnaturalizam ajudando-nos a reconhecer sua contradição e diferença.

Vários outros traços da narrativa épica são reapropriados na novela canadense. No entanto, Atwood não estiliza nem parodia a divisão da estruturação épica clássica - organizada em proposição, invocação, dedicatória, narração e remate. A escritora concentra-se no uso e abuso de outras convenções, tais como os componentes da mecânica da narrativa épica, listados pelo teórico inglês Cecil M. Bowra (1952). Em sua abordagem sobre a narrativa heroica, Bowra realiza um inventário de tais constituintes, que se não têm necessariamente força dentro da narrativa épica, mas ajudam ao menos a compô-la. Nas palavras de Bowra:

Sem elas, o público pode não conseguir seguir o que está acontecendo. [...] mas essas passagens podem se tornar atrativas e iluminadoras e adicionar poesia ao efeito geral. Elas não chamam muita atenção para si [...] mas dentro de suas limitações podem oferecer um charme discreto e aumentar o prazer que temos pela luz que jogam nos personagens e nas circunstâncias de suas vidas (BOWRA, 1952, p. 179).

Entre os elementos pertencentes à mecânica épica estão: as chegadas e partidas, os atos de despertar e ir para a cama, banquetes, com uso de bebidas e entorpecentes, viagens pelo mar, trocas de roupas, cuidados pessoais, entre outros. Seu uso ostensivo e repetitivo, embora discreto, acaba por torná-los idiossincráticos à narrativa épica ${ }^{36}$. Um bom exemplo é a cena em que Penélope narra como descobriram em Ítaca que Helena havia sido raptada por Páris:

A primeira notícia sobre a catastrofe iminente chegou pelo capitão de um navio espartano que atracou em nosso porto. A nau empreendia viagem por nossas ilhas remotas, comprando e vendendo escravos, e como de costume, no caso de visitantes de certa importância, recebemos o capitão com um banquete e o hospedamos no palácio. (ATWOOD, 2006, p.70)

As descrições da chegada de um visitante e da preparação de um banquete para servi-lo que vemos acima são exemplos de cenas prototípicas, cuja inclusão na épica clássica reforça sua fundamentação na apresentação, isto é, no ver e no contemplar sem alteração de ânimo. A partir de sua inclusão, o poeta pode prrencher as lacunas entre as passagens mais impressionantes, tornar mais claro o

\footnotetext{
${ }^{36}$ Matthew Clark (2014) argumenta que, em poemas escritos, a técnica da cena prototípica oferece ao poeta uma estrutura básica de suporte, mas também lhe permite adaptar cada cena para propósitos específicos. A semelhança entre as cenas contribui para a manutenção da simétrica épica. (CLARK, 2014, p. 135).
} 
que acontece, manter o ritmo narrativo e o ar de realidade (BOWRA, 1952, p.214). Na narrativa contemporânea, funcionam mais como um meio de enfatizar certas nuances épicas no texto, já tão privado de procedimentos estilísticos típicos do gênero. Estes, durante a modalização genérica operada por Atwood se fazem notar mais por sua ausência e subversão, como num filme em negativo.

Outro aspecto que merece atenção é a quase ausência do maravilhoso e dos deuses em A odisseia de Penélope. Howells ressalta que a novela "é drenada do aspecto sobrenatural" (HOWELLS, 2006, p.9). Nas epopeias homéricas, ao contrário, as divindades e o sobrenatural têm um papel fundamental. A crítica Emily Kearns ressalta esse status modalizante que os deuses têm na Ilíada e na Odisseia, pois, como já foi dito anteriormente, apresentam uma função de causalidade - as ações, ideias e emoções dos personagens são determinadas por intervenções deles. Eles interferem diretamente na vida dos personagens e, por conseguinte, na narrativa: tomam partido em situações, chegando a se envolver fisicamente nelas, e se apresentam aos humanos por meio de disfarces, de oráculos ou em sonhos.

$\mathrm{Na}$ Odisseia, os deuses aparecem de maneira diferente da que são retratados na Ilíada, além de se apresentarem em número menor. Além disso, parecem ter sido "atenuados [...], ter se tornado menos coloridos, menos claramente individualizados" (KEARNS, 2014, p. 67). Tal fato provavelmente está relacionado ao escopo do enredo da segunda epopeia homérica. Apesar de ser apresentado como um herói de qualidades superlativas, Odisseu é apenas um indivíduo, e a história se desenvolve em torno de seu triunfo. Por mais que mereça atenção dos deuses, não tem a importância de uma terrível guerra que dura anos.

Em A odisseia de Penélope, os deuses nunca se manifestam ou mostram-se presentes. $\mathrm{Na}$ contemporaneidade, momento em que a história é narrada, os deuses, como afirma Penélope, "foram todos dormir. No mundo de hoje as pessoas não recebem mais visitas dos deuses como antigamente, a não ser que tomem drogas" (ATWOOD, 2006, p.33). Os comentários que a esposa de Odisseu faz sobre eles são invariavelmente jocosos, "num pernicioso descrédito em relação ao mito" (HOWELLS, 2006, p.10), que Howells reconhece como típico ceticismo pós-moderno: "[i]magino os deuses flanando no Olimpo, sorvendo néctar e ambrosia, maliciosos como um grupo de meninos de dez anos. [...] Creio que boa parte das gracinhas deles se deve ao tédio (ATWOOD, 2006, p.112). 
Mesmo quando recapitula os eventos do passado e as aventuras do marido, os deuses e seu poderio são questionados. As ocasiões em que Odisseu trava contato com deuses, semideuses e criaturas míticas são consideradas apenas mentiras, rumores ou exageros, com caráter contraditório, que não podem ser levados a sério. Como podemos observar no capítulo em que Penélope nos fala das notícias que chegavam durante a espera pelo marido :

Dia após dia eu subia ao andar superior do palácio e ficava observando o porto. De vez em quando surgiam navios, mas nunca os navios que eu queria ver. Rumores chegaram trazidos por outras naus.[...] Odisseu enfrentara um grande ciclope de um olho só, segundo alguns; nada disso foi só um taberneiro caolho com quem brigou por causa da conta. [...] Odisseu residia numa ilha encantada, como hóspede de uma deusa, diziam alguns ; ela trandofrmara seus marinheiros em porcos - nenhuma proeza nisso, em minha opinião - e os tranformara em homens depois de se apaixonar por Odisseu e alimentá-lo com iguarias extravagantes preparadas por suas próprias mãos divinas, e os dois deliravam ao fazer amor todas as noites; que nada, diziam outros, era só um puteiro chique e ele tomava dinheiro da cafetina. (ATWOOD, 2006, p. 76)

Todos os rumores que envolvem elementos sobrenaturais - o ciclope, a ilha encantada, a deusa - adquirem uma outra explicação que lhes retira o elemento mágico e lhes dá uma feição realista. Várias passagens, nas quais há notória intervenção dos deuses na Odisseia, quando espelhadas na versão de Atwood, não apresentam a intervenção divina como explicação. Um bom exemplo é a passagem do canto XXI, quando da chegada de Odisseu, Penélope se recolhe a seus aposentos a pedido de Telêmaco, e adormece antes do embate final de seu marido com os pretendentes por influência de Atená: "Acompanhada das servas aos quartos de cima foi logo/ para chorar pelo caro marido Odisseu, té que sono/ muito tranquilo nos olhos lhe Palas Atena vertesse" (Odisseia, canto XXI, v.356-358). $\mathrm{Na}$ Odisseia de Penélope, a protagonista atribui o sono a uma bebida que lhe foi oferecida por Euricleia, como vemos no seguinte trecho :

Dormi durante o tumulto. Como pude fazer uma coisa dessas? Desconfio que Euricleia acrescentou algo à reconfortante bebida que me ofereceu para me tirar de cena e evitar minha interferência" (ATWOOD, 2006, p.127).

Dessa forma, percebemos que o tratamento dado ao maravilhoso na obra é, conforme afirma Coral Ann Howells, tanto "uma celebração quanto uma subversão do mito em um processo revisionista autoconsciente, na medida em que Atwood mescla padrões míticos num rede reconhecível de relações humanas contemporâneas (HOWELLS, 2006, p.10). 
Vemos, portanto, que por meio de uma reescrita desconstrucionista da Odisseia, Atwood subverte-a por meio da modalização do gênero épico. Esse processo de modalização se dá a partir da desconstrução do mito e da reapropriação, estilização e incorporação de seus procedimentos estilísticos ao gênero da novela. Assim, a obra funciona, como propõe Leite (1995), como um 'reativador genérico' da epopeia clássica. Nesse processo paródico de modalização do épico, tornam-se claras as injunções ideológicas subjacentes ao texto homérico, que Atwood subverte e desnaturaliza, dando-lhe um outro contexto. Sob um viés claramente feminista, cumpre sua agenda feminista e dá voz a Penelope e às aias, além de questionar a autoridade de um texto canônico, ao apresentar uma alternativa a ele. 


\section{6 \\ A Odisseia de Homero (segundo João Vítor), de Gustavo Piqueira: o épico infanto-juvenil}

Um clássico é algo que todos gostariam de ter lido e ninguém gostaria de ler.

Um clássico é um livro que as pessoas elogiam, mas não leem.

Mark Twain

As frases que servem como epígrafes para este capítulo foram proferidas pelo escritor norte-americano Mark Twain durante o discurso "Address at the Dinner of the Nineteenth Century Club", realizado em 1900, na cidade de Nova York. O escritor pregava a valorização da literatura norte-americana e ressaltava a distância dos clássicos em relação ao público leitor norte-americano em geral. A partir de tais declarações, podemos depreender duas crenças sobre o clássico enraizadas até hoje em nosso imaginário. A primeira diz respeito à difícil acessibilidade do clássico para a maior parte do público leitor, seja pela linguagem rebuscada ou pela temática abordada. O processo de leitura se mostraria penoso e infrutífero, não se estabelecendo a rede de sentidos passíveis de ativação pelo contato com o texto. A segunda envolve a percepção de que um clássico apresenta um conjunto de valores e princípios caros à formação do indivíduo que devem ser transmitidos e ensinados. É de extrema importância, portanto, que ele se preserve e continue a ser lido. Assim, o clássico se configuraria simultaneamente como algo necessário, mas de difícil acesso e compreensão.

De fato, como observa Maria Teresa Andruetto, esses textos permanecem entre nós "por sua condição de inesgotáveis, sua capacidade de seguir dizendo além de seu tempo e de sua geografia. É a resistência que oferecem à possibilidade de serem interpretados num sentido completo que os converteu em clássicos" (ANDRUETTO, 2012, p. 129). Entretanto, cabe-nos ressaltar que as mesmas inesgotabilidade e resistência que garantem a sobrevivência dessas obras elevam-nas inevitavelmente a um status canônico. A partir de sua canonização, as obras se fixam, endurecem e tendem a se converter em monumento. 
Andruetto atenta para um paradoxo envolvendo o cânone: a monumentalização das obras advém como uma consequência inesperada da necessidade de que os valores nelas expressos se perpetuem. O cânone, afirma ela, "é uma leitura do presente rumo ao passado, para decidir o que ensinar, o que antologiar, como fazer para que certos livros permaneçam vivos e sejam lidos pelas gerações que nos seguem" (ANDRUETTO, 2012, p. 34). Entretanto, a crítica rejeita uma ideia de cânone que se restrinja a um conjunto de ideias e de normas fixas engessadas e propõe que a literatura tenha num movimento permanente e dialético de acomodação entre centro e periferia, no qual textos canônicos e não canônicos se desloquem na busca de uma melhor inserção de seus modelos. Afinal, ressalta Andruetto "todo cânone necessita da ameaça externa - a ameaça do não canônico -, e é desse exterior não canonizado que se originam as reservas da literatura que virá" (ANDRUETTO, 2012, p.33). O não canônico então adquire aqui um papel renovador e até mesmo transformativo do cânone, que a partir dele se revigora e ganha sobrevida.

Ana Maria Machado (2002) também defende a desmonumentalização do clássico/canônico, advogando sua leitura desde a infância. A escritora consideraos "um legado riquíssimo, que se trata de um tesouro inestimável que nós herdamos e ao qual temos direito" e afirma que, além disso, lê-los pode ser ao mesmo tempo uma forma de resistência e fonte de inúmeras formas de prazer, que envolveriam desde o mero entretenimento até o gosto pela viagem e o prazer da exploração e da decifração (MACHADO, 2002, p.19).

Em relação aos clássicos gregos, Machado afirma que são "uma fonte inesgotável, onde sempre podemos beber" e "iniciar por eles nossa viagem pelos clássicos" (MACHADO, 2002. p.26). Tal posicionamento é compartilhado por inúmeros pensadores, como Settis $(2005)^{37}$ e Fiorin $(1991)^{38}$, e constitui uma visão tradicional de que, ao conhecer os gregos e latinos, estamos travando contato com um passado cuja importância está nele mesmo. Como já discutimos no capítulo 1 - e gostaríamos de reiterar - o clássico também representa uma

\footnotetext{
${ }^{37}$ De acordo com Settis (2005): "o passado 'clássico' apresenta uma eterna atualidade porque ele contém e evidencia as raízes comuns da civilização ocidental, oferece à União Europeia um fator identitário comum. Da mesma forma que a tradição judaico-cristã, ele corporifica os grandes valores compartilhados pela cultura europeia e de origem europeia, das Américas e da Austrália.(SETTIS, 2005, p.10)

${ }^{38}$ Para José Luiz Fiorin (1991): “conhecer nossas origens significa conhecer também as culturas grega e latina. Elas são, pois, uma herança a conservar e uma tradição de conhecimento a transmitir" (FIORIN, 1991, p.515).
} 
interrogação ao presente, que contribui, entre outras coisas, para o entendimento de nossa formação identitária e de nossa cultura.

A recomendação de Machado levanta uma questão: como começar desde a infância a leitura dos clássicos diante da dificuldade de decodificação desses textos? A resposta é simples: essa leitura deve envolver alguma forma de mediação, sendo a adaptação literária a mais comum delas.

$\mathrm{Na}$ literatura brasileira, temos uma série de obras que apresentam a cultura clássica grega para o público infanto-juvenil a partir de narrativas que incluem a apropriação dos mitos e seus personagens. Foi iniciada por Monteiro Lobato no livro Reinações de Narizinho (1931), ao qual se seguiram O Picapau Amarelo (1931), O minotauro (1939) e a série Os doze trabalhos de Hércules (1944), que compreende 12 livros, a saber: O touro de Creta, A hidra de Lerna, Hércules e Cérbero, Leão de Neméia, O javali de Erimanto, A corça dos pés de bronze, As cavalarias de Augias, Os cavalos de Diomedes, Os bois de Gerião, O cinto de Hipólita, As aves do Lago de Estinfale e O pomo das Hespérides. Segundo Nelly Novaes Coelho, em Panorama histórico da literatura infantil/juvenil (2010):

Nessas adaptações ${ }^{39}$, Lobato atendeu a um duplo objetivo: por um lado de levar o conhecimento da Tradição (com seus heróis reais ou fictícios, seus mitos [...] etc.), acervo herdado que lhes caberá transformar, e, por outro lado questionar as verdades feitas, os valores e não valores que o Tempo cristalizou e que cabe ao presente redescobrir ou renovar (COELHO, 2010, p.253).

Essa possiblidade de renovação do clássico a partir de sua adaptação defendida por Coelho insere o clássico em um movimento dinâmico e evita seu processo de monumentalização. Esse movimento iniciado no Brasil por Lobato é seguido ainda por Flávia Lins e Silva, com As Peripécias de Pilar na Grécia (2001), e Lia Neiva, em Entre deuses e monstros (2007), obras nas quais a cultura clássica é também apresentada ao público infantil/juvenil por meio de sua inserção em narrativas contemporâneas.

Outra vertente de apresentação da cultura clássica para o público infantojuvenil, mais comum no exterior, envolve a condensação, quadrinização ou síntese de epopeias homéricas. Amplamente adotadas em escolas, elas têm uma função iniciática e consistem "em um dispositivo didático/metodológico que se configura numa forma de difundir a literatura" (GRIJÓ, 2007, p. 96). Muitos críticos

${ }^{39}$ Nely Novaes Coelho aqui se refere à adaptação dos mitos. 
acusam tais adaptações serem reducionistas, pelo fato de "fatiarem" o texto e excluírem aspectos seus mais poéticos. No Brasil, porém, temos adaptações que são sucesso de crítica como, por exemplo, os trabalhos de Ruth Rocha (2004), Roberto Lacerda (2008), Gustavo Piqueira (2013) e outros.

Rocha realizou, provavelmente, a adaptação das epopeias homéricas para o público infantil mais famosa e bem sucedida comercialmente no Brasil. Lançadas em 2010, já se encontram na oitava reimpressão. Nas duas edições, intituladas Ruth Rocha conta a Ilíada e Ruth Rocha conta a Odisseia, a autora sintetiza as obras de Homero, como anuncia a contracapa da obra que trata da Ilíada, "para aproximar os jovens leitores desta obra, a autora acrescentou uma continuação, compilando lendas, histórias e peças teatrais que contam o final da Guerra de Troia" (ROCHA, 2010).

As edições trazem uma introdução e um resumo para ajudar no entendimento da cronologia da Guerra de Troia - elementos primordiais para a compreensão da Ilíada e da Odisseia. Contam também com um texto que aborda sinteticamente a Questão Homérica. Dessa forma, Rocha dá ao leitor ferramentas de abordagem ao texto e adapta sua linguagem. Em entrevista ao site Educar para crescer, da Editora Abril, porém, ela afirma: “dou um tom mais infantil à obra, mas não fico tentando buscar palavras que sejam mais fáceis. O livro é uma forma de enriquecer o vocabulário, [...] precisa respeitar o original” ${ }^{\prime 4}$. Assim vemos que duas características parecem ser primordiais na concepção de Ruth Rocha - sua fidelidade ao original e seu teor educativo.

Outra adaptação bastante curiosa é a do escritor e ilustrador paulista Gustavo Piqueira, na qual o processo de adaptação ocorre de forma um tanto diferente daquela executada por Rocha. Em A odisseia de Homero (segundo João Vítor), o protagonista João Vítor, aluno da sexta série do Ensino Fundamental, precisa escrever um trabalho sobre a Odisseia, pedido pela professora Denise. No entanto, por causa de um engano, o menino lê o texto original, enquanto seus colegas leram uma adaptação infantil. A narrativa se desdobra em dois níveis por um lado, temos os acontecimentos da Odisseia e, por outro, o relato do choque que a leitura causa no menino e suas considerações sobre o texto, que

\footnotetext{
${ }^{40}$ Cf. "Leitura não pode ser só folia - entrevista com Ruth Rocha." Disponível em http://educarparacrescer.abril.com.br/leitura/entrevista-ruth-rocha-401466.shtml. Último acesso em 20/12/2016.
} 
beiram o absurdo. Como o contato do menino com texto se dá sem a mediação da professora, ele acaba por conferir à narrativa um tom cômico e carnavalesco. De forma semelhante às de Ruth Rocha, a obra de Piqueira conta com adendos e paratextos explicativos, destacando assim, sua preocupação didática e referência ao original.

Gostaríamos, portanto, de questionar, como é objetivo maior desse trabalho, se podemos considerar adaptações infantis uma das configurações do gênero épico na contemporaneidade. Engendrar-se-iam nelas os processos de modalização do gênero épico que vimos na epopeia contemporânea, no romance e na novela? A fim de levarmos a cabo tal discussão, tomaremos a obra de Piqueira como corpus de análise.

Para procedermos à leitura da adaptação que o autor realiza da Odisseia e à sua comparação com as demais obras já analisadas precisamos antes situar a questão genérica que nos é imposta aqui. Antes, porém, de investigarmos a presença ou não de estratégias de modalização do gênero épico, precisamos discutir sobre literatura infanto-juvenil e sobre os conceitos de adaptação e adaptação infanto-juvenil.

\section{1 \\ Literatura Infantil e adaptação}

Para a pesquisadora Nelly Novaes Coelho (2000), a literatura infantil se situa em uma intersecção entre a arte literária e a Pedagogia, tendo assim uma natureza dupla: ao mesmo tempo em que é entretenimento e provoca emoções, ensina e provoca uma mudança na consciência de mundo do leitor. Essas duas facetas da literatura infantil não são arbitrárias, são, antes, consequência do entrelaçamento da intenção educativa com a artística que lhe é peculiar desde o seu surgimento. A amplitude e a distância entre esses dois pólos permite que uma grande variedade de obras, com intenções e naturezas distintas, seja definida pelo rótulo de "literatura infantil" (COELHO, 2000, p. 46).

Em detalhado estudo sobre o assunto, o crítico Peter Hunt (2010) também observa essa dupla função, a qual considera problemática, pois: 
Para alguns, literatura infantil bem que pode ser uma contradição em termos: os valores e qualidades que constituem naturalmente a "literariedade" (isto é, que passaram a ter significado culturalmente) não podem ser sustentados seja por livros destinados a um público com experiência, conhecimento, habilidade e sofisticação limitados, seja pelos leitores (HUNT, 2010, p.287).

As pesquisadoras Maria José Palo e Maria Rosa Oliveira, observando esse paradoxo, afirmam que neste entrelaçamento entre arte literária e pedagogia implica vê-la "como uma atividade complexa e por isso não natural ao universo da infância" (PALO \& OLIVEIRA, 2006, p.7). Assim, faz-se necessário facilitá-la por meio de inúmeras estratégias para possibilitar a compreensão infantil do fenômeno estético. Tal processo coloca, por vezes, o literário numa posição de mero instrumento para a obtenção da finalidade educativa. A literatura infantil, para que esse impasse se resolva, precisa:

Propor-se enquanto proto-pedagogia ou quase-pedagogia capaz de rever-se em sua estratificação de código dominador do ser literário infantil, para, ao recebê-lo em seu corpo, banhar-se também na qualidade sensível desse ser com o qual deve estar em harmônica convivência (PALO \& OLIVEIRA, 2006, p.14).

Assim, o aspecto artístico e o pedagógico se conciliam na obra literária infantil - a fruição do poético também envolve um aprendizado: a tomada de consciência de mundo a partir da construção de sentido.

Para que se efetue a construção de sentido, duas habilidades são primordiais. A primeira é a compreensão do funcionamento da língua em sua mecânica e seus processos de denotação e conotação. Entretanto, nas obras infantis, a linguagem tende a ser simplificada, e os eventos, tratados em geral com maior linearidade, a contiguidade e até mesmo o uso de imagens de modo a complementar o que é oferecido pelo texto escrito. A outra é mais complexa, no entendimento de alusões culturais e de como os textos operam a partir de estruturação genérica. Ao contrário dos adultos - letrados -, as crianças são leitores em desenvolvimento. A forma como elas abordam textos visando a construção de sentido é totalmente diferente da forma como os adultos letrados o fazem. Elas podem desconhecer regras de gêneros que regem os textos e que geram expectativas em relação a eles. Por isso, os significados que elas atribuem aos textos em suas leituras, tendem a ser muito mais idiossincráticos e particularizados (HUNT, 2010, p.135).

Curiosamente, um dos traços característicos da literatura infantil - e que nos interessa sobremaneira nesta discussão - é a sua mistura genérica. Na 
contemporaneidade, a ideia de livro como forma fechada vem sendo substituída por uma experiência multidimensional:

A literatura infantil, talvez de forma mais óbvia que as outras formas literárias, desde o início fez parte disso - adaptando, refazendo, absorvendo - e foi movida simultaneamente por criatividade, interesse e mercantilismo. Os livros-ilustrados na segunda metade do século XX se tornaram sede de alguns dos trabalhos mais complexos, experimentais, polifônicos e multirreferenciais do universo textual (HUNT, 2010, p.288).

Acreditamos que essa natureza multirreferencial, complexa e experimental esteja presente em A Odisseia de Homero (segundo João Vítor), de Gustavo Piqueira, a qual analisaremos após uma pequena discussão sobre a questão da adaptação de obras canônicas para o público infantil.

\section{2 \\ Adaptação e adaptação para jovens leitores}

Passemos, pois, à questão da adaptação na literatura De acordo com o Penguin Dictionary of Literary Terms, "em termos gerais a adaptação envolve refundir um texto originalmente em um meio para encaixá-lo em outro" (CUDDON, 1999, p.8). A definição - curta e objetiva - é seguida de exemplos de peças e romances que foram transpostos para o cinema e a televisão. Apesar de proceder, essa definição mostra-se superficial demais para abarcar as inúmeras possiblidades que o fenômeno da adaptação percebe nos dias de hoje.

O crítico francês Georges Bastin concebe a adaptação como "um processo de operações tradutórias que resultam em um texto que não é considerado uma tradução, mas que é, entretanto, reconhecido por representar o texto fonte" (BASTIN, 1998, p.5). Bastin ainda ressalta que é possível classificar a adaptação de acordo com critérios específicos, tais como os modos pelos quais as adaptações são realizadas, as condições que levaram à decisão de adaptar o texto e as restrições que permearam o trabalho do adaptador. O crítico então oferece um longo inventário de procedimentos de adaptação, no qual ressalta as múltiplas técnicas que o processo pode envolver: a transcrição do original; a omissão de partes ou sua expansão com vistas a tornar o sentido de certas passagens mais explícito; a substituição de palavras por equivalentes, por razões de adequação ao 
contexto ou atualização; a inserção de um contexto mais familiar do que o usado no original e até mesmo a substituição do texto como um todo, preservando apenas a mensagem essencial (BASTIN, 1998, p. 7).

Bastin aponta a mudança de gênero textual e a inadequação situacional como possíveis condições para que uma adaptação seja realizada e ainda destaca três restrições a que o adaptador acaba por se submeter:

- O conhecimento e as expectativas do leitor-alvo: o adaptador tem que avaliar até que ponto o conteúdo do texto original constitui uma informação nova ou compartilhada do público potencial;

- A língua-alvo: o adaptador deve encontrar uma correspondência apropriada na língua-alvo para o estilo do discurso do texto original e procurar coerência nos modos de adaptação;

- O sentido e o(s) propósito(s) do texto original e o texto-alvo. (BASTIN, 1998, p.7-8).

Assim vemos que um processo de adaptação textual é cruzado por inúmeras variáveis, que influenciam e norteiam a produção do texto-alvo. Interessa-nos aqui, sobretudo, a adaptação literária para o público infantil que implica uma recriação textual. Ana Maria Machado (2002) concebe a adaptação literária infantil como um texto facilitado e de extensão reduzida, que funciona como uma introdução/apresentação para outro texto - de caráter canônico -, com o qual o jovem leitor provavelmente travará contato depois. Machado ressalta sua natureza parafrásica da adaptação literária infantil e destaca seu papel importante em um processo de formação de leitores.

A natureza parafrásica da adaptação infantil dos clássicos também é apontada por Mario Monteiro. Em dissertação de mestrado defendida na PUCRio, em 2002, Monteiro aborda a questão da adaptação do texto literário para o público infantil, encarando-a como uma atualização textual. Ele ressalta que adaptações, que são muito comuns e mais aceitas na Europa, têm um importante papel didático. São geralmente destinadas ao público escolar e suas vendas não são efetuadas à base da compra por impulso, mas, principalmente, à base da compra por adoção. As escolas adotam os livros, visando a apresentação dos textos canônicos para os alunos. Nas palavras de Monteiro:

Os chamados clássicos adaptados são criações por encomenda, tendo como base somente títulos de domínio público. Possuem mercado consumidor garantido em nossas salas de aula porque, normalmente, baseiam-se em obras que integram os cânones da literatura ocidental. São livros que se propõem a ser fiéis à essência do original (que Michel Foucault, em A ordem do discurso, chamaria de texto primeiro - aquele historicamente anterior, o 
que pode ser reconhecido como o primeiro da linhagem). E a confiança nesta fidelidade é vital para os professores que os adotam. Na prática, os professores são os consumidores e os alunos, usuários; afinal são os professores que determinam a compra. Quebre-se a confiança que os professores têm nos clássicos adaptados e será o fim deste segmento editorial (MONTEIRO, 2002, p. 7, grifo do autor).

Dessa maneira, as adaptações de obras literárias para o público infantojuvenil são, por seu caráter voltado principalmente para a venda e para o lucro, vistas por muitos com um subproduto capitalista. De acordo com a lógica econômica e mercantilista em que vivemos, os cânones literários se tornaram um bem de consumo, pois o "reconhecimento, por parte da crítica, da importância de determinadas obras faz com que estas sejam constantemente reeditadas e comercializadas" (MONTEIRO, 2002, p.4). No que tange à qualidade, Monteiro ainda observa que a boa adaptação funciona como uma tradução do texto original, fazendo a ponte entre períodos culturais distintos. Além disso, uma boa adaptação é aquela que visa expandir ao máximo a base de leitores de uma obra literária. (MONTEIRO, 2002, p.9-10). Tais intenções permitem que esses textos sejam classificados como paráfrases.

A paráfrase, segundo Afonso Romano de Sant'anna, apresenta diversos sentidos. Em estudo sobre a distinção entre paródia e paráfrase, ele afirma que esta última se refere à:

reafirmação, em palavras diferentes, do mesmo sentido de uma obra escrita. Uma paráfrase pode ser uma afirmação geral da ideia de uma obra como esclarecimento de uma passagem difícil. Em geral ela se aproxima do original em extensão (SANT'ANNA, 2003, p.17).

Quando tentamos contrastá-las à noção que temos de adaptações literárias para o público infantil, vemos que elas, por se destinarem a um público de leitores em desenvolvimento, demandam a inclusão de um aspecto condensador ou sintético à noção de paráfrase.

Além disso, a priori, toda paráfrase envolve algum tipo de interpretação. Entretanto, consiste numa interpretação que se dá, "repousando sobre o idêntico e o semelhante, pouco faz evoluir a linguagem. Ela se oculta atrás de algo já estabelecido, de um velho paradigma" (SANT'ANNA, 2003, p.28). Assim vemos que a adaptação literária de clássicos para o público infanto-juvenil, na qualidade de paráfrase, repousa sobre os paradigmas tradicionais veiculados pelos textosfonte, seguindo em geral as injunções ideológicas de seu contexto de produção. 
Em discussão acerca da adaptação infantil de clássicos, Andréa Grijó (2007) observa que o diálogo estabelecido entre ela e o texto fonte tende a privilegiá-lo, de maneira diferente da que ocorre como outros diálogos intertextuais: "O valor está no texto original, tanto que, na maior parte das vezes, é o nome do autor desse original que aparece na capa - e o do adaptador em segundo plano, quando não é omitido" (GRIJÓ, 2007, p.97). Tal movimento se dá por uma razão especificamente: porque, invariavelmente, a obra adaptada é canônica; já foi criada uma aura em torno dela. Temos a ideia de que lidamos não com um livro qualquer, mas com uma obra que, como propõe Leyla Perrone-Moisés, tem valor de grife $^{41}$.

As adaptações infantis então consistem em um recurso ao mesmo tempo didático, artístico e mercadológico que tem como intenção tornar a leitura de uma obra canônica possível para um público que não é o previsto pelo autor do original. Entre os mecanismos normalmente utilizados para alcançar esses objetivos, segundo Grijó, estão: a "supressão de trechos, sínteses, alterações sintáticas e morfológicas, explicitação de contextos, todos compreendidos aqui como resultado de escolhas do adaptador para interagir com os leitores, nesse caso, jovens leitores" (GRIJÓ, 2007, p.101). Vemos, assim, pelos mecanismos supracitados que, muito embora as adaptações infantis não sejam necessariamente uma mera condensação da obra, os autores tendem a se preocupar muito mais com aquilo que está sendo contado, em detrimento do modo como é contado.

Tal afirmação tem muito peso quando se fala de uma adaptação infantil de uma epopeia. Se esse padrão - de privilegiar o enredo em relação à forma - for seguido, temos apenas uma releitura sintética do mito. O helenista Walter Burkert reforça que o conceito de "narrativa épica não é idêntico a mito; não vive de estruturas iniciais, mas da formação de pormenor, está ligada [...] a uma linguagem artificial própria, desenvolvida para esse fim” (BURKERT, 2001, p.38). Portanto, para poder ser considerada uma manifestação modalizada do gênero épico, a adaptação infantil deve ter sua linguagem - literária e visual -

\footnotetext{
${ }^{41}$ A crítica Leyla Perrone-Moisés (1998) defende a ideia de que a indústria cultural cria e manipula um valor de grife para autores com a intenção de divulgar e aumentar as vendas de seus produtos a leitores que não têm discernimento para escolher e julgar as obras. Monteiro (2002) apresenta uma boa discussão acerca do assunto.
} 
trabalhada de forma que os expedientes estéticos épicos estejam presentes, além da incorporação dos expedientes míticos.

Na próxima seção, demonstraremos como Gustavo Piqueira parece não se adequar à essa concepção de adaptação. Sua obra, A odisseia de Homero (segundo João Vítor), transcende a mera reprodução do mito, realizando uma modalização do gênero épico ao mesmo tempo em que problematiza o papel do cânone e das adaptações literárias no processo de formação do leitor. Seu texto está muito mais próximo de um eixo parodístico do que de um eixo parafrásico, como a maioria das adaptações, pois conforme afirma Sant'Anna:

Do lado da ideologia dominante, a paráfrase é uma continuidade. Do lado da contra-ideologia, a paródia é uma descontinuidade. [...] Falar de paródia é falar de intertexualidade de diferenças. Falar de paráfrase é falar de intertextualidade de semelhanças. [...] Também se pode estabelecer outro paralelo: paráfrase como efeito de condensação, enquanto a paródia é um efeito de deslocamento. Com a condensação, temos dois elementos que se equivalem a um. Com o deslocamento, temos um elemento com a memória de dois. Por isto é que se pode falar do caráter ocioso da paráfrase e do caráter contestador da paródia (SANT'ANNA, 2003, p.28-29, grifo do autor).

Como veremos a seguir, a releitura da Odisseia realizada por Piqueira apresenta, pois, um caráter inegavelmente paródico, carnavalesco e subversivo, tanto na exploração da forma quanto no tratamento que confere ao mito, uma vez que descontinua ideologicamente, desloca e contesta a epopeia homérica.

\section{3}

\section{A modalização épica em A odisseia de Homero (segundo João Victor)}

Ao escrever A odisseia de Homero (segundo João Vítor) (2013), o escritor Gustavo Piqueira realiza seu primeiro trabalho voltado para o público infantojuvenil. Nascido em São Paulo, Piqueira é arquiteto, ilustrador e designer gráfico por formação, tendo recebido mais de sessenta prêmios ao longo da carreira. Como escritor, tem inúmeros livros publicados, entre eles: Morte aos papagaios (2004), Manual do paulistano moderno e descolado (2007), A vida sem graça de Charlinho Peruca (2010), Iconografia Paulista (2012), Clichês Brasileiros (2013), Lorde Creptum (2015), Lululux (2015) e Valfrido (2016). Na visão do 
autor, todos se caracterizam por uma mistura de design, história, arte e literatura, que resulta em narrativas contemporâneas que testam os limites da linguagem.

A odisseia de Homero (segundo João Vítor) é seu primeiro livro dedicado ao público infantil. No posfácio da obra, Piqueira revela que a motivação de escrever uma adaptação da Odisseia surgiu quando, já adulto, ao ler a versão integral da epopeia homérica, deu-se conta de que era bem diferente da versão que havia lido na infância:

Sim, o dito 'essencial' da narrativa estava lá, em ambas as versões [...] Mas na versão de minha infância, não havia os primeiros cantos dedicados a Telêmaco. E a narrativa era linear, não como a original na qual grande parte dos fatos era contada em retrospectiva por Ulisses na corte de Alcínoo [...] Sem falar nos inúmeros costumes e práticas morais da época descritos no livro, habilmente eliminados de minha primeira versão. Por trinta anos, menti que conhecia a Odisseia, Porque o que eu conhecia era uma parte da Odisseia. Uma sinopse, um resumo, não a Odisseia (PIQUEIRA, 2013, p.152).

O autor, portanto, ressalta a precariedade das adaptações infantis existentes no mercado e questiona sua validade. Sobre essa questão, a crítica Eliana Yunes, embora não discuta especificamente sobre adaptações infantis dos clássicos, aponta, de forma semelhante a Piqueira, para esse aspecto muito frequente nas edições de obras da literatura infantil, a mutilação artística do texto, muitas vezes em detrimento de seu aspecto visual. Além disso, ressalta que, na produção de literatura para crianças, há uma extrema desigualdade entre emissor e receptor, uma vez que o adulto produz e compra o texto, cabendo à criança apenas o papel de mera consumidora da mensagem (YUNES, s/d). ${ }^{42}$

Tendo isso em mente, Piqueira cria a história de João Vítor, menino que como já foi dito anteriormente - tem que escrever um trabalho sobre uma adaptação da Odisseia, mas acaba por ler a versão integral. O livro narra a leitura de João Vítor, que assume o papel ativo de mediador da epopeia homérica para o leitor. A falta de preparo do menino resulta em uma leitura truncada e absurda, que confere um tom cômico e carnavalesco à epopeia clássica, desconstruindo-a.

O crítico literário Peter Hunt ressalta que, por serem ainda leitores em desenvolvimento, crianças tendem a atribuir a um texto sentidos diferentes daqueles elaborados por leitores experientes, por inúmeras razões. Em seu processo de leitura, as crianças são, segundo Hunt, desconstrutoras de textos por

\footnotetext{
${ }^{42}$ Literatura infantil e sócio-semiotica. In: Revista de Ciência e Cultura.
} 
excelência, "prontas para ler 'contra' os textos, para usá-los como base para leituras extravagantes, livre das aborrecidas restrições do entendimento" (HUNT, 2010, p.148). Então, para a criança-leitora, todo ato de leitura de um texto que se configure como um universo do discurso desconhecido por ela será um ato de desconstrução.

É exatamente isso que acontece com João Vítor: a Odisseia posiciona-se como um universo discursivo ao qual ele é alheio e, por isso, sua leitura resulta na desconstrução. Esse processo é resultado de uma lacuna entre a experiência de vida do menino - sua experiência com textos e sua estrutura de referências - e as oferecidas pelo texto como um todo. Afinal de contas, não há sentido fixo estabelecido a priori pelo texto. Nas palavras da pesquisadora Louise Rosenblatt:

Todo ato de leitura é um acontecimento, ou uma transação, que implica um leitor em particular e um padrão de signos em particular, um texto (um acontecimento), que ocorre num momento particular e dentro de um contexto particular. Em lugar de duas entidades fixas que atuam uma sobre a outra, o leitor e o texto são aspectos de uma situação dinâmica total. O "significado" não existe de "antemão" no "texto" ou no "leitor", mas desperta ou adquire entidade durante a transação entre o leitor e o texto (ROSENBLATT, 1996, p. 25-25).

Um bom exemplo de tal diferença na estrutura de referências é a passagem em que, após a leitura do canto 1 da Odisseia, João Vítor questiona a existência de deuses que não correspondam ao padrão judaico-cristão:

Começou mal, hein? "um deus chamado Poseidon"? Como assim, professora Denise? Não faz sentido. Deus só tem um e ele se chama Deus mesmo. E seu filho não é nenhum "ciclope Polifemo", mas Jesus. Que até o Fumaça sabe, foi crucificado e não cegado. Quem é, então, esse ciclope Polifemo? Também não sei o que é uma ninfa. De correto só o fato de Ulisses não poder se casar com Calipso, mesmo se quisesse. Com duas pessoas ao mesmo tempo, não dá. É a lei. Seria necessário, primeiro, pedir o divórcio para a primeira mulher. Mas com Ulisses preso à ilha, impossível encontrar a esposa e assinar a papelada da separação (PIQUEIRA, 2013, p. 16).

O protagonista mostra-se completamente alheio à cultura grega clássica. Ele nem ao menos ouviu falar de Homero, não reconhece, portanto, seu valor de grife. Fica assustado com a ausência de um sobrenome para o autor na capa do livro e o batiza Homero da Silva.

Seus quadros de referência, portanto, não conseguem abarcar o contexto da epopeia. Sua leitura resvala no absurdo. Por ser ainda um leitor em desenvolvimento, João Vítor não consegue ter as chamadas expectativas genéricas ao ler a obra de Homero. Segundo M. Meek, tais expectativas "nos possibilitam 
entender o suspense, identificar a coesão em um texto, atribuir importância a eventos, decidir com que tipo de livro estamos lidando e o tipo de atenção que o livro exige" (MEEK apud HUNT, 2010, p.115).

A falta de expectativas genéricas leva João Vítor a não entender e questionar a divisão em cantos: "[n]este livro, os capítulos chamam-se "cantos", não “capítulos”. Não sei bem o motivo. Talvez porque o livro deva ser cantado, não lido? O que o tornaria a mais longa música do mundo, pois é um tremendo calhamaço" (PIQUEIRA, 2013, p.13). O mesmo acontece quando o menino, ignorando a inalterabilidade de ânimo do narrador épico ${ }^{43}$, reclama da "falta de suspense" ao ler o canto 8, por já saber que era a Ulisses que as canções de Demódoco se referiam:

Malfeito, professora Denise. Malfeito até a última linha. Homero da Silva quis criar um suspense no fim do capítulo, percebeu? "Quem será o misterioso viajante?" [...] O problema é que todo mundo sabe quem é ele. Todo mundo. Eu, a senhora e o resto do planeta (PIQUEIRA, 2013, p.60).

Piqueira, assim, problematiza a recepção e o status do épico clássico na contemporaneidade bem como o ensino dos clássicos da literatura na escola. Em entrevista ao blog do Instituto Moreira Salles, o escritor revela que o livro é "mais uma interpretação da Odisseia do que uma adaptação" e acrescenta que:

Uma das intenções (a outra, não menos importante, era me divertir com a possibilidade de distorcer a "Odisseia" pelas lentes embaçadas do protagonista) foi mostrar o quanto da subjetividade inerente a qualquer processo cognitivo individual, como a leitura de um livro é talhada quando o outro decide a priori que a obra em sua forma integral não é adequada (ou pior, atraente) para determinado público ou época. Porque, ainda que estapafúrdias, todas as associações que João Vítor faz a partir de sua leitura da Odisseia não passam de versões hiperbólicas das que todo leitor faz ao ler qualquer livro ${ }^{44}$.

Podemos dizer que mais que uma interpretação da segunda epopeia atribuída a Homero, a obra é uma reapropriação paródica da epopeia, uma vez que os procedimentos estilísticos, os mitos e as estruturas narrativas presentes no gênero aparecem aqui justapostos a outros que lhes são alheios para serem por eles desafiados.

\footnotetext{
${ }^{43}$ João Vítor também é de certa forma narrador de uma epopeia, mas não se mantém inalterável e distante dos acontecimentos, fazendo juízos de valor a todo momento.

${ }^{44}$ Disponível em: http://gustavopiqueira.com.br/assets/odisseia03-site.pdf.. Último acesso em 12/12/2016.
} 
O enredo da Odisseia reaparece na obra narrado canto a canto por João Vitor, que faz uma leitura que pode ser considerada carnavalesca, por conter "os protocolos e estilos da alta cultura em uma posição de rebaixamento" (BAKHTIN, 1984, p.83). Os referenciais clássicos aparecem, aqui, imiscuídos e atualizados por referenciais da cultura pop contemporânea. Tal movimento, que é a tônica da obra de Piqueira como um todo, pode ser exemplificado pela passagem a seguir, quando, durante a leitura do canto 11, Ulisses desce ao Hades e encontra, entre outras almas, Epicasta. João Vítor compara então a epopeia com a telenovela:

Outra morta que chamou minha atenção [...] foi Epicasta. Ela se casou com o próprio filho, Édipo, e este, ainda por cima, assassinou o pai. Parece novela, não? [...] Suplício de um adeus era o título. O título de uma novela que se parecia com a história de Epicasta. [...] Bem parecido. Homero da Silva certamente copiou. Certamente. Burrice dele, pois muita gente assistiu a Suplicio de um adeus. O nome disso é plágio, professora Denise. Plágio (PIQUEIRA, 2013, p.85-86).

João Vítor então passa a misturar as histórias, incorporando os personagens da telenovela à narrativa dos acontecimentos na Odisseia. A narrativa de João Pedro, a partir desse ponto, adquire um tom folhetinesco. João Vítor sonha que é filho de Ulisses e Penélope. Numa cena típica de telenovelas, Mamacita, personagem de Suplício de um adeus e empregada da vilã, a condessa Torremolinos, lhe revela:

Mamacita sussurra ao meu ouvido: "Você não é filho de Ulisses e Penélope! Você é filho da condessa Torremolinos!" Não! Da condessa não! A condessa Torremolinos entra, cavalgando o monstro Cila. Vem com a mamãe, vem, pituxinho!” Pituxinho? Não! (PIQUEIRA, 2013, p.101)

Assim, vemos que a justaposição de personagens da telenovela e de outros da epopeia provoca um entrelaçamento carnavalesco de estilos e registros, que elimina a distinção entre cultura erudita e cultura popular. (MCHALE, 1987, p.184). Num movimento paródico típico da ficção pós-moderna, a hierarquia entre os gêneros literários se desfaz - a epopeia está amalgamada à telenovela. Cabenos ressaltar, aqui, que tal justaposição do erudito com o popular já vinha em curso pela própria adaptação para o público infanto-juvenil da epopeia, pois como ressaltam Palo e Oliveira, a literatura infantil é vista, em nossa cultura, geralmente como "uma forma literária menor, atrelada à função utilitário-pedagógica, que a faz ser mais pedagogia que literatura" (PALO \& OLIVEIRA, 2006.p.9). 
Também é interessante notar a apropriação do recurso epopeico dos epítetos na caracterização dos personagens. Esses epítetos, na epopeia, caracterizam os personagens a partir de seus traços físicos ou estados de ânimo, por meio de comparações em geral com o mundo natural. De acordo com Matthew Clark, o uso de epítetos pode ocorrer nas epopeias clássicas por causa de seu aspecto ornamental, por causa de sua força para a caracterização das personagens ou ainda por ser útil em sua métrica para a construção do verso (CLARK, 2014, p. 128). Na obra de Piqueira, João Vítor acaba conferindo epítetos a alguns personagens. Ulisses é um dos que recebem um novo epíteto. No canto 6, após o encontro com as servas de Nausicaa, o herói toma banho num rio e Atena torna-o mais alto e mais forte, e encaracola seus cabelos. João Vítor passa a chamá-lo de Ulisses Poodle ${ }^{45}$, como observamos no trecho a seguir: "Poseidon, seguindo os passos cafajestes de Ulisses Poodle, decidiu se aproveitar da coitada e [..] se disfarçou de Rio" (PIQUEIRA, 2013, p.84) Temos ainda como exemplo, Hermes, mensageiro dos deuses, que recebe a alcunha de Hermes, motoboy fofoqueiro: "Ulisses soube dessa reunião entre Zeus e o Sol por Calipso, que por sua vez, recebera a informação enquanto futricava com "Hermes, o motoboy fofoqueiro" (PIQUEIRA, 2013, p.84). Assim vemos que a tradição dos epítetos é retomada na obra de Piqueira apenas para ser ironizada por meio da paródia, pois, como afirma Hutcheon, essa é uma forma de representação irônica e que obedece a um código duplo: "ela tanto legitima quanto subverte aquilo que parodia" (HUTCHEON, 1995, p.101).

O gênero épico se notabiliza, como já foi dito anteriormente, por uma linguagem de grande plasticidade. Assim sendo, quando o gênero é adaptado para um livro ilustrado, é natural que a linguagem visual adquira um papel preponderante. As imagens do livro - pelas quais Piqueira ganhou os prêmios o How International Design Awards (2014) e IDA International Design Awards (2015) - utilizam a técnica da colagem e do pastiche, que mesclam imagens neoclássicas do artista inglês John Flaxman (1755-1836) e elementos da cultura contemporânea.

\footnotetext{
${ }^{45}$ A partir dessa passagem, o personagem Ulisses aparece nas imagens com uma peruca semelhante ao pelo de um cachorro poodle. A caracterização, à semelhança dos epítetos na epopeia permanece ao longo da narrativa. Cf. Anexos. Imagem 1.
} 
Expoente do neoclassicismo inglês, Flaxman dedicou-se à escultura e ao desenho, tendo produzido diversas gravuras com base nos mitos gregos ao longo de sua carreira. Essas gravuras, cuja coleção completa se encontra na Tate Gallery, em Londres, denotam grande respeito ao paradigma clássico, sobretudo no que concerne à harmonia das formas e à seriedade moral. $\mathrm{O}$ helenista David Irwin salienta que sua escolha e tratamento de temas demonstram que, apesar de Flaxman não se esquivar de temas mais apaixonados e momentos impactantes da escrita de Homero, ele tendia a minimizá-los, tornando-os mais suaves e sóbrios (IRWIN apud WEBB, 2014, p. 292-293).

A suavidade e sobriedade presentes nas gravuras de Flaxman são justapostas a elementos contemporâneos. Valendo-se da técnica da colagem, Piqueira cria imagens que refletem a visão e o pensamento do menino protagonista - nosso mediador nesta leitura da Odisseia. De acordo com Renato Cohen, a colagem envolve "a justaposição [...] de imagens não originalmente próximas, obtidas através da seleção e picagem de imagens encontradas, ao acaso, em diversas fontes" (COHEN apud VARGAS \& SOUZA, 2012, p.54). A partir do emprego da técnica, que viabiliza um grande grau de experimentação e confrontação com a arte tradicional, "o artista transforma imagens e objetos em composições abstratas ou com algum grau de figuratividade. A rigor, o que está no cerne da colagem é a tensão entre o peso de realidade dos objetos materiais" (VARGAS \& SOUZA, 2011, p.54).

As colagens de Piqueira justapõem os personagens da Odisseia - na austeridade em que foram concebidos por Flaxman - a elementos da cultura contemporânea, muitas vezes reproduzidos em série por meio de fotografias. Numa das imagens que ilustram o canto $8^{46}$, podemos ver que as imagens neoclássicas de Odisseu e seus homens aparecem misturadas a recortes de elementos da cultura contemporânea como churrasqueiras, ventiladores, sanfonas, lanternas e drinks. As inserções não obedecem à localização/disposição correta dos objetos, em relação ao plano espacial: aparecem invertidas, causando efeito surrealista. Nessa crispação entre a arte neoclássica e imagens da cultura de massa, o autor simultaneamente retrata a confusão da mente do menino João Vítor

\footnotetext{
${ }^{46}$ Cf. Anexo 2.
} 
e promove um desafio às noções de arte clássica e cultura de massa, tornando a fronteira entre elas menos rígida.

Piqueira ressalta a eloquência do design de seus livros, que, segundo ele, "não se limita ao papel de entregador de pizza" nem serve somente como elemento decorativo ou interface de leitura. De fato, sua obra é a soma de texto, imagens e projeto gráfico. Podemos dizer que, mais do que eloquentes, as imagens do livro reproduzem, em sua natureza carnavalesca, a grandiloquência e a plasticidade da linguagem épica. O uso exagerado de cores e a repetição ad nauseam de formas - bem como a disposição dos elementos nas páginas - nos permitem afirmar isso. Muitas são as páginas em que não há moldura e as imagens sangram a margem do livro, tomando completamente seu espaço, o que Sophie Van der Linden classifica como "uma espécie de espetacularização":

As imagens sangradas causam essa impressão de poderem se estender para além da página dupla. Bem diferentes das emolduradas, que têm uma relação dinâmica com o suporte, e as imagens vazadas resultam afinal de uma expressão singular, investem e reapropriam o suporte, o qual se coloca inteiro a seu serviço. Cada imagem se sobrepõe exatamente à anterior, permitindo assim uma forte cadência no livro [...] (VAN DER LINDEN, 2011, p.74).

Em A odisseia de Homero (segundo João Vítor), as páginas sangradas são aquelas em que João Vítor adormece e tem um pesadelo no qual tudo acontece muito repentinamente. Desse modo, a velocidade frenética dos acontecimentos do pesadelo é expressa por meio do sangramento sequencial de imagens ${ }^{47}$. Ainda precisamos ressaltar que há uma variação nos enquadramentos e na disposição de gravuras, que ajuda a conferir à narrativa uma velocidade incongruente à da epopeia clássica, que é baseada no desenrolar progressivo dos episódios. Tal velocidade é incompatível com a contemporaneidade, o que faz João Vítor reclamar: "foi só isso o que aconteceu no capítulo! Versão caminhão ou não, a Odisseia segue devagar-quase-parando, professora!” (PIQUEIRA, 2013, p. 54).

A obra de Piqueira ainda apresenta três partes, que funcionam de certa forma como paratextos, informando o texto e complementando-o. São elas: "Odisseia de João Vítor (segundo Gustavo Piqueira)", "Odisseia de Homero através dos séculos" e "Breve Enciclopédia da Odisseia (sem João Vítor para atrapalhar)". Na primeira seção, o autor fala sobre sua experiência de leitura da

${ }^{47}$ Cf. Anexo 3. 
Odisseia e critica a forma na contemporaneidade tratamos a leitura de obras clássicas como um grande checklist: o importante é ter contato com a obra, não a forma como este contato se dá. A argumentação de Piqueira e seu relato de experiência levam-nos a refletir sobre a condição do épico clássico em nosso século: por seu constante uso e abuso, conhecemos muito pouco sobre ele, muito embora pensemos o contrário: "falamos dele de uma forma cada vez mais sem vida, padronizada e atrofiada" (SETTIS, 2006, p.2).

Além disso, vemos que o escritor parece alarmado com as versões adaptadas, que tentam "transformar a história de Ulisses numa história que poderia ser protagonizada pelos X-Men, trocando-se apenas figurino, vilões, cenários" (PIQUEIRA, 2013, p.156). Desse modo, acabam por fazer nosso contato com o épico se perder por completo. Evidencia-se, assim, outro traço que caracteriza a postura contemporânea em relação não só ao épico, mas também ao clássico, diagnosticado por Mary Beard: "uma sensação nostálgica de perda iminente, um medo perene de estarmos à beira de perder o clássico por completo" (BEARD, 2012, p. 12).

Na seção posterior, o autor apresenta uma iconografia sobre a Odisseia - que engloba desde as representações em cerâmicas gregas a pinturas expressionistas do século XX e dá conta de mostrar a dimensão e o rastro de influência do épico homérico em nossa cultura. Ante as inúmeras feições e diferentes traços que os personagens adquirem nas pinturas, o que fica evidente é o fato de cada época e cultura atualizar o clássico de acordo com seus quadros de referência, incorporando a ele novos elementos. Já ao final do livro, o autor contextualiza o épico clássico e explica detalhes obliterados ou incompreendidos da leitura de João Vítor, aproximando o leitor do original e preparando-o, de certa forma, para sua leitura. Então, podemos afirmar que o uso de paratextos aqui tem uma natureza didática e visa fornecer ao leitor reflexões acerca da condição do épico clássico hoje, além de informações complementares para que ele possa dar coerência à narrativa de João Vítor. A leitura que o menino faz do clássico é de uma contemporaneidade inegável; é acima de tudo irônica, fragmentada e difusa.

Assim vemos que a obra de Piqueira, ainda que de forma sutil e indireta, sinaliza o status do clássico na contemporaneidade, como "referência acadêmica essencial à formação e como reinvenção do passado que supõe essa referência e amplia-a introduzindo o novo" (ARAUJO, 2011, p 19). A obra constitui uma 
adaptação sui generis e paródica da Odisseia, se as compararmos às outras adaptações infanto-juvenis, que são baseadas, sobretudo, na paráfrase. Por ter um caráter paródico, A odisseia de Homero (segundo João Vítor) consegue engendrar uma modalização do gênero épico, que aparece a partir inserção de determinações temáticas e formais do gênero épico ao discurso literário infanto-juvenil. 


\section{7 \\ Conclusão}

$\mathrm{Na}$ introdução desta tese, propusemos investigar a permanência do gênero épico na contemporaneidade e caracterizá-lo a partir do levantamento dos procedimentos estilísticos, temas e motivos típicos da epopeia clássica que são reapropriados e modalizados em diferentes gêneros na literatura contemporânea. Também propusemos analisar a maneira como essas diferentes configurações do épico se relacionam com outras questões, como o mito fundacional e o clássico. Cabe ressaltar ainda, que nosso foco é nos épicos de referência clássica, ou seja, devedoras da tradição homérica.

Esperamos ter tornado clara a situação dos postulados acerca da epopeia nos dias de hoje. Escrever epopeias hoje, nos moldes homéricos, conforme sugerido por Aristóteles, é impossível. Isso não quer dizer, no entanto, que a epopeia e o gênero épico morreram. Ao contrário, temos uma vasta produção de obras que, se não podem ser consideradas epopeias, são certamente representantes do gênero épico na literatura contemporânea. Por isso, surge a necessidade de pensar a epopeia em seu caráter evolutivo e no investimento de outros gêneros sobre ela.

Teóricos como Anazildo Vasconcelos da Silva e Christina Ramalho (2007) e Saulo Neiva (2009) advogam a ideia, da qual partilhamos, de que as epopeias continuam sendo realizadas nos dias de hoje. Elas continuam a ser escritas em forma de versos e a apresentar uma dupla instância de enunciação, da mesma forma que a epopeia clássica. Alguns pesquisadores priorizam (de forma algo reconstrutivista) uma sobreposição do elemento lírico em relação ao narrativo. Outros, como a portuguesa Ana Mafalda Leite, observam a permanência do gênero épico a partir de sua hibridização com outros gêneros: Leite defende a ideia de que a presença do gênero também se dá por um processo de modalização, a partir do qual um gênero combina-se a outro - cujas características são determinantes em termos de classificação - incorporando seus modos e entrecruzando seus temas e formas. De acordo com Leite, "um termo modal a classificar um género implica, pois, que alguns procedimentos [...] de um outro género são extensivos à modificação do gênero em causa" (LEITE, 1995, p.33). Assim sendo, o termo para nos referirmos ao gênero modalizado ganha uma 
função adjetiva e se liga a um substantivo, como, por exemplo, o vocábulo "épico" na expressão "romance épico". O modo, conforme articulado por Leite, é transformativo e dá conta das mudanças e metamorfoses genéricas: "ele não somente é um gênero mais solto, colateral a um gênero fixo, mas também seu sucessor" (LEITE, 1995, p.33). Desse modo, podemos dizer que outros gêneros se filiam à epopeia, modalizando-a, formando gêneros que apresentam um cunho épico. Acrescentamos ainda uma peculiaridade: a maior parte das obras em que se modaliza o gênero épico o faz visando à ironização e desconstrução, a partir de estratégias narrativas paródicas.

Outro ponto importante que temos que ressaltar é a colocação do pesquisador norte-americano J. B. Hainsworth de que "não há épico que não confronte seus predecessores; os temas recorrentes no épico - o heroísmo, a nação, fé - são ideias em evolução" (HAINSWORTH, 1991, p.vii). Assim, todas as obras de cunho épico estariam filiadas a uma obra épica anterior. Todas as obras analisadas nesta tese apresentam algum tipo de relação explícita com outros épicos, seja por um diálogo intertextual direto com uma obra específica, como $A$ odisseia de Penélope, de Margaret Atwood e A odisseia de Homero (segundo João Vítor), de Gustavo Piqueira - que fazem alusões à epopeia homérica desde o título -, seja pela reapropriação paródica e irônica de elementos epopeicos, como Viva o povo brasileiro de João Ubaldo Ribeiro, ou ainda, por estabelecer um feixe de relações hipertextuais com vários textos épicos, como é o caso de Uma viagem à Índia, de Gonçalo Tavares.

Em sua obra, Gonçalo Tavares aponta para a (im)possibilidade de se escrever uma epopeia na contemporaneidade a partir de sua desconstrução, estabelecendo relações intertextuais com Os Lusíadas, de Camões, a Odisseia, de Homero e Ulisses, de James Joyce. Salientando em entrevista que "a epopeia no século XXI não pode ser igual à epopeia dos séculos clássicos”, Tavares reapropria-se da estrutura do gênero - no caso, de Os Lusíadas - articulando-a com uma matéria romanesca e ambientando-a na primeira década do nosso século. A obra apresenta um tom fortemente autorreflexivo e se autodenomina epopeia, como podemos ver no seguinte trecho do canto V: "Vai para Londres, Bloom, pelo ar - voltámos, pois, ao início da epopeia” (TAVARES, CANTO V, 6, p.204). Entretanto, se levarmos em consideração os critérios estabelecidos por Silva e Ramalho (2007) para a definição de um texto como epopeia na 
contemporaneidade, vemos que a obra não se configura como tal. Ela não conjuga uma dupla instância de enunciação a uma matéria épica. Faz uso, entretanto, de uma matéria romanesca, além de situar a ação no presente. A obra Uma viagem à Índia deve ser lida, portanto, na clave da modalização do gênero épico, pois o épico nela se engendra a partir da incorporação irônica e estilizada de elementos soltos do poema épico a um poema e da revisitação desconstrutora de dois motivos épicos: a figura do héroi e as viagens iniciática e de retorno (nóstos). Tavares subverte a invocação épica e o ideal de linguagem épica plástica e grandiloquente. O protagonista revela-se um homem de seu tempo: é um herói problemático, melancólico e niilista, que ironicamente resvala, por vezes, na caracterização do pícaro romanesco. Bloom embarca para a Índia num avião, em busca de esquecimento e sabedoria, para realizar uma viagem que não modifica sua natureza nem sua forma de ver o mundo, como se revela já na proposição do poema:

Falaremos da hostilidade que Bloom, nosso herói, revelou em relação ao passado, levantando-se e partindo de Lisboa numa viagem à Índia, em que se procurou sabedoria e esquecimento.

E falaremos do modo como na viagem Levou um segredo e o trouxe, depois, quase intacto. (TAVARES, CANTO I, 10, p.28).

Assim, percebemos que Tavares "subverte o sentido da viagem canónica do Ocidente em aventura de ilusão de todas as buscas divinas e epopeia luminosa de decepção" (LOURENÇO, 2010, p.10). A modalização do gênero épico em Tavares dá contorno a uma obra de classificação problemática; caracteriza-se, portanto, por sua subversão e seu esvaziamento.

Já em Viva o povo brasileiro, João Ubaldo Ribeiro faz o percurso em direção oposta ao de Tavares: escreve um romance épico, modalizando expedientes épicos no gênero do romance. Assim, o escritor se insere na tradição da literatura brasileira de narrativas de fundação. Por lidarem com as questões da história e dos mitos fundadores para forjar e assegurar a criação de uma identidade nacional, essas narrativas acabam por adquirir um tom épico. Ubaldo, entretanto, situa seu texto na contramão da asserção de uma identidade nacional una e fixa, em contraposição à visão dos fatos propagada pela história oficial, revelando seu 
caráter ideológico. No obra, o personagem Filomeno Cabrito, uma espécie de rapsodo cego do sertão, parece explicitar essa visão de história à qual o escritor quer desconstruir:

Mas a história, explicou o cego, não é só essa que está nos livros, até porque muitos dos que escrevem livros mentem meias do que os que contam histórias em Trancoso. [...] Além disso, continuou o cego, a História feita por papéis deixa passar tudo aquilo que não se botou no papel e só se bota no papel o que interessa. Alguém que tenha o conhecimento da escrita pega de pena e tinteiro para botar no papel o que não lhe interessa? Alguém que roubou escreve que roubou, quem matou escreve que matou, quem deu falso testemunho escreve que foi mentiroso? Não confessa. Alguém escreve bem do inimigo? Não escreve. Então toda história dos papéis é pelo interesse de alguém (UBALDO, 2014, p.506-507).

Assim, vemos que Ubaldo utiliza o gênero épico para problematizar a narrativa do mito de fundação e a noção de verdade histórica. Ainda, ao priorizar personagens anônimas, o escritor subverte o plano histórico da narrativa, elevando à categoria de heróis personagens ficcionais que não fazem parte da história do Brasil oficial, ressaltando seu caráter construído e representacional.

$\mathrm{Na}$ obra, temos vários indícios da modalização do épico no romance: a linguagem plástica e grandiloquente, o uso do catálogo e alusões a personagens de epopeias. No entanto, o aspecto mais notável está na presença do maravilhoso, típica de epopeias, que se dá por meio da incorporação ao texto de mitos nagôiorubá, empregados como metáforas, símbolos como dispositivo da paródia. Um bom exemplo é o diálogo intertextual estabelecido com a Ilíada, de Homero, quando recruta deuses africanos, os orixás, como aliados dos negros na Guerra do Paraguai. O capítulo 14 oferece uma magistral cena de teomaquia, nos moldes da Ilíada, com muitos requisitos da mecânica épica propostos por C. M. Bowra (1952). Assim, pode-se dizer que há um pastiche do discurso entretecido de maravilhoso, o que só vem a confirmar nossa visão de que Viva o povo brasileiro modaliza o gênero épico, desconstruindo-o e carnavalizando-o de forma polifônica e paródica.

Em A Odisseia de Penélope, por sua vez, a escritora feminista Margaret Atwood se reapropria da Odisseia, de Homero, modalizando o gênero épico - que se notabiliza por sua extensão e grandiosidade - em uma novela, forma de proporções breves por excelência. Atwood posiciona Penélope e as aias como narradoras do mito da Odisseia, cumprindo assim uma agenda feminista. As versões das narradoras se opõem à de Homero - forma pela qual a escritora realça 
o ponto de vista eminentemente masculino pelo qual a escrita da epopeia homérica se engendra. No entanto, as versões femininas também apresentam discrepâncias entre si. Segundo Coral Ann Howells:

Atwood está jogando em dois níveis do mito aqui: o mito homérico da Penélope fiel e os mitos culturais sobre as mulheres, que as retratam ou como submissas e domésticas, ou como criadoras dúbias de ardis e femme fatales. [...] Atwood enfoca as contradições evidenciadas por esses estereótipos de gênero ao mesmo tempo em que espreita por entre as lacunas na narrativa de Homero. [...] Penélope permanece um enigma, seu nome enterrado embaixo do peso de séculos de fofocas e rumores, apesar de ser uma figura lendária. Desse modo, Atwood está livre para reinventá-la, de modo que Penélope possa vigorosamente parodiar mitos de heroísmo masculino e fazer comentários irreverentes sobre os deuses (HOWELLS, 2005, p.9).

Além disso, diversos procedimentos estilísticos e motivos da epopeia clássica aparecem completamente invertidos: a inalterabilidade de ânimo é quebrada, o tom solene e grandiloquente torna-se confessional e conversacional, a simetria épica é parodiada, entre outros. Temas e motivos recorrentes típicos da epopeia ganham um novo viés, não correspondendo à expectativa gerada por seu uso. Assim, vemos que o processo de modalização efetuado por Atwood envolve, sobretudo, a desconstrução paródica dos modos épicos inseridos na narrativa. Como num filme em negativo, os expedientes épicos podem ser lidos na novela a partir de sua inversão.

Por fim, na obra destinada ao público infantil A Odisseia de Homero (segundo João Vítor), o escritor e designer Gustavo Piqueira - de forma semelhante a Margaret Atwood - promove a desconstrução paródica e carnavalesca da Odisseia. A modalização do gênero ocorre a partir da leitura que o menino João Vítor faz da versão integral do texto homérico, quando sua professora, na verdade, havia utilizado uma adaptação infantil. O resultado beira o absurdo: libações aos deuses tornam-se churrascos; Ulisses adquire novos e inimagináveis epítetos; o enredo de uma telenovela imiscui-se à narrativa e assim por diante. Piqueira, desse modo, questiona não só o valor conferido e a adequação do épico clássico aos nossos dias, mas também problematiza a questão das adaptações literárias. Em entrevista, o autor revela que considera seu livro mais uma interpretação do que uma adaptação:

Eu zombo daquelas adaptações com fins facilitadores - que agem como se uma música fosse apenas seu refrão. [...] Será que existe algum valor absoluto em simplesmente "termos contato" com as coisas? Ou isso não 
passa de uma obsessão contemporânea. tratarmos a vida como um grande checklist? Vale para crianças ou adultos e tanto faz se o checklist inclui clássicos da literatura, viagens pelo mundo, restaurantes, museus. Quando elencamos a lista do que "precisamos ter contato" e saímos a ticar os boxes, não estamos transformando o mundo num enorme mercadão? ${ }^{48}$

Em sua tentativa de zombar das adaptações com fins facilitadores, Piqueira escreve uma adaptação sui generis, que não se restringe à mera paráfrase do texto original, mas que carnavaliza a epopeia clássica tanto narrativa quanto nas imagens, que de forma irônica reproduzem a grandiloquência épica. Assim, percebemos que a modalização do gênero épico é, sobretudo, carnavalesca.

Tendo em vista tudo o exposto ao longo desta pesquisa, vemos que as configurações aqui analisadas revelam uma presença modalizada do gênero épico na literatura contemporânea. Assim como qualquer outra modalidade do paradigma clássico, o épico encontra-se em franco processo de desconstrução, dada a crise nos processos de representação que marca a modernidade. Para o pesquisador Aparecido Rossi, o retorno do épico no contexto da contemporaneidade,

dramatiza a busca (falha) por uma explicação de si mesmo empreendida pelo sujeito contemporâneo. [...] À maneira épica, essa busca dá-se em um movimento de olhar para o passado tomando-o como exemplo cabal, rememorando-o, revisitando-o, e ou mesmo (re)construindo-o e/ou (re)inventando-o (ROSSI, 2009, p. 150).

As obras épicas de referência clássica têm em geral um relacionamento ambíguo com as epopeias canônicas. Ao mesmo tempo em que reconhecem seu valor e sua força, promovem sua ressignificação, pois colocam em relevo questões que elas tendem a obliterar. Na literatura contemporânea, os épicos de referência clássica atualizam temas e motivos épicos, em um movimento que revela mais sobre a condição contemporânea do que sobre o passado. Das obras analisadas aqui, nenhuma pode ser classificada como epopeia - nem no sentido restrito proposto por Aristóteles, nem no mais amplo, proposto por outros teóricos estudados. Todas apresentam um processo de modalização, conforme aventado por Leite (1995), pois em sua associação a outros gêneros, na atualidade, o épico deixa de ser um gênero e passa a ser um modo; um discurso que é parodiado, estilizado, estetizado, reescrito, reinventado por meio de inúmeras estratégias narrativas, dando origem a múltiplos avessos de sua matriz clássica.

\footnotetext{
${ }^{48} \mathrm{http} / / /$ gustavopiqueira.com.br/assets/odisseia03-site.pdf Ultimo acesso: 25/01/2017.
} 


\section{8 \\ Referências bibliográficas}

ANDRUETTO, María Teresa. Por uma literatura sem adjetivos. Trad. Carmen Cacciacarro São Paulo: Pulo do Gato, 2012.

ARAÚJO, Carolina. "O clássico como problema". Disponível online: http://www.poiesis.uff.br/PDF/poiesis11/Poiesis_11_clasprob.pdf. Último acesso: $23 / 07 / 2015$.

AUERBACH, Eric. Mímesis: a representação da realidade na literatura ocidental. Trad. Equipe Perspectiva. São Paulo: Perspectiva, 2010.

ATWOOD, Margaret. The Penelopiad. New York: Canongate, 2005.

A odisseia de Penélope. Trad. Celso Nogueira. São Paulo: Companhia das Letras, 2005.

BAKHTIN, Mikhail. Questões de literatura e de estética: a teoria do romance. Trad. A. F. Bernardini et al. São Paulo: Editora UNESP, 1998.

. Rabelais and his world. Trad. Helene Iswolsky.

Bloomington: Indiana UP, 1984.

BASTIN, Georges. "Adaptation”. In: BAKER, Mona et all. The Routledge

Encyclopedia of Translation Studies. New York: Routledge, 1998, p. 710.

BAUDELAIRE, Charles. "O pintor da vida moderna". In: A modernidade de Baudelaire. Tradução de Suely Cassal. Rio de Janeiro: Paz e Terra, 1988.

BAUMAN, Zigmunt. O mal-estar da pós-modernidade. Trad. Mauro Gama e Cláudia Martinelli Gama. Rio de Janeiro: Zahar, 1998.

BEARD, Mary. "Do the Classics Have a Future?". In: The New York Review of Books. Janeiro, 2012.

BOITANI, Piero. A Sombra de Ulisses. Trad. Sara Margelli e Carlos Alberto Dastoli. São Paulo: Perspectiva, 2005. 
BORDINI, Maria Isabel da Silveira. "Uma viagem à Índia, de Gonçalo M. Tavares: uma epopeia contemporânea”. In: Revista Versalete. Curitiba. Vol.1 n ${ }^{\circ}$ zero, jan-jun 2013.

BORGES, Jorge Luis. Curso de Literatura Inglesa. Trad. Eduardo Brandão. São Paulo: Martns Fontes, 2006.

BOWRA, Cecil M. Heroic poetry. London: Macmillan, 1952.

BRANDÃO, Junito de Sousa. Mitologia grega. Vol.3. Petrópolis: Vozes, 1999.

BRISSON, Luc. Introdução à filosofia do mito. Trad. José Carlos Bacarat Junior. São Paulo: Paulus, 2014.

BRITTO, Paulo Henriques. "Poesia e memória" In: PEDROSA, Célia (org.) Mais poesia hoje. Rio de Janeiro: 7 letras, 2000.

BRUNEL, Pierre. Mythopoétique des genres. Paris: Presses Universitaire de France, 2003.

BUENO, Kim Amaral. "Contratempos durante a viagem à Índia, com Gonçalo Tavares". Nau Literária: crítica e teoria de literaturas. Porto Alegre, Vol.09, nº1, jan-jun 2013.

BUKERT, Walter. Mito e mitologia. Coleção Perspectivas do Homem. Lisboa: Edições 70, 2001.

CAIRUS, Henrique. "O lugar dos clássicos hoje: o super cânone e seus desdobramentos no Brasil". Disponível online: http://www.letras.ufrj.br/proaera/super-canone.pdf. Útimo Acesso: $23 / 07 / 2015$

CALVINO, Italo. Por que ler os clássicos. Trad. Nilson Moulin. São Paulo: Companhia das Letras, 2007.

CARREIRA, Shirley de Souza Gomes. "O diálogo intertextual em A odisseia de Penélope, de Margaret Atwood" In: Revista Eletrônica do Instituto de Humanidades, v.7, $\mathrm{n}^{\circ}$ 26, jul-set 2008. 
CARNEIRO. Geraldo. "O amador e a coisa amada" In: RIBEIRO, João Ubaldo. Viva o povo brasileiro. Rio de Janeiro: Nova Fronteira, 2005.

CARTER, Ronald \& John Mac Rae. The Routledge History of Literature in English. London: Routledge, 1997.

CECCANTINI, João Luis C. T. “João Ubaldo Ribeiro: no plural a unidade.” In: Revista de Letras. Assis/SP, 1994, n. 34, p. 49-60.

CIXOUS, Hélène. "The Laugh of the Medusa". Signs, Vol. 1, No. 4 (Summer, 1976), pp. 875-893.

CLARK, Matthew. "Formulas, metre and type scenes". In: FOWLER, Robert.

The Cambridge Companion to Homer. London: Cambridge University Press, 2014, p.117-138.

COELHO, Nelly Novaes. Literatura Infantil: teoria, análise e didática. São Paulo: Moderna, 2000.

CUDDON, J. A. The Penguin Dictionary of Literary Terms and Literary Theory. London: Penguin, 1999.

CUNHA, Eneida Leal. "Viva o povo brasileiro: história e imaginário". In: Portuguese Cultural Studies. Number 1. Spring 2007.

CUNHA, Helena Parente. Os Gêneros Literários. In: PORTELLA, Eduardo.(org) Teoria Literária. Rio de Janeiro: Tempo Brasileiro, 1999, pp.93-130.

D’ONOFRIO, Salvatore. Da Odisseia ao Ulisses: evolução do gênero narrativo. São Paulo: Duas Cidades, 1981.

DUARTE, Pedro. O estio do tempo. Rio de Janeiro: Zahar, 2011.

ELIOT, T.S.. "What is a classic?" Disponível online: http://bracchiumforte.com/PDFs/tseliot.pdf. Ultimo acesso: 30/12/2016.

FELSON, Nancy \& Laura Slatkin. "Gender and Homeric Epic". In: FOWLER, Robert (ed.). The Cambridge Companion to Homer. Cambridge: Cambridge University Press, 2014, p.91-114. 
FIORIN, José Luís. "Letras clássicas no segundo grau: competência textual e intertextual” In: CARDOSO, Zelia (org.). Mito, religião e sociedade. Atas do II Congresso Nacional de Estudos Clássicos. São Paulo: 1991.

FOLEY, Helene P. "Women in Ancient Epic" In: FOLEY, John Miles (ed.) A Companion to Ancient Epic. Oxford: Blackwell Publishing, 2005, p.105118.

FUSILLO, Massimo. "Epic, novel”. In: MORETTI, Franco. The novel: forms and themes. New Jersey: Princeton University Press, 2006.

GADAMER, H.G. Verdade e método: traços fundamentais de uma hermenêutica filosófica. Tradução de Flávio Meurer. Petrópolis: Vozes, 1997.

GRIFFIN, Jasper. "The Speeches" In: FOWLER, Robert (ed.). The Cambridge Companion to Homer. Cambridge: Cambridge University Press, 2004, p156-167.

GRIJÓ, Andréa. "Quem conta um conto aumenta um ponto. adaptações e literatura para jovens leitores". In: PAIVA, Aparecida et all. (org.). Literatura: saberes em movimento. Belo Horizonte: Ceale, 2007, p.93107.

GOLDIN, Daniel. Os dias e os livros: divagações sobre a hospitalidade da leitura. Trad. Carmen Cacciacarro. São Paulo: Pulo do Gato, 2012.

GUNTHENKE, Constance. "Romanticism" In: GRAFTON, Anthony et all (eds). The Classical Tradition. Cambridge: Harvard University Press, 2010.

HAINSWORTH, J. B. The idea of epic. Los Angeles: University of California Press, 1991.

HALL, Stuart. A Identidade cultural na pós-modernidade. Tradução: Tomás Tadeu da Silva e Guacira Lopes Louro. Rio de Janeiro: DP\&A Editora, 1999.

HARVEY, Paul. Dicionário Oxford de literatura clássica grega e latina. 12a ed. Tradução de Mário da Gama Kury. Rio de Janeiro: Jorge Zahar Editor, 1998. 
HELENA, Lucia. “A narrativa de fundação: Iracema, Macunaíma e Viva o povo brasileiro. In: Revista Letras. Número 6: jul/dez, Santa Maria 1993.

HUNT, Peter. Crítica, teoria e literatura infantil. Trad. Cid Knipel. São Paulo: Cosac Naify, 2010.

HUTCHEON, Linda. The Politics of Postmodernism. New York: Routledge, 1989.

Poética do Pós-Modernismo: história, teoria, ficção. Trad. Ricardo Cruz. Rio de Janeiro: Imago, 1991.

A theory of parody: the teachings of twentieth century art and forms. Londres, Nova Iorque, Methuen,1985.

HOMERO. Ilíada (em forma de narrativa). Trad. Carlos Alberto Nunes. Rio de Janeiro: Ediouro, 1996.

. Ilíada. Trad. Frederico Lourenço. São Paulo: Penguin Classics/ Companhia das Letras, 2011.

Odisseia. Trad. Frederico Lourenço. São Paulo: Penguin Classics/ Companhia das Letras, 2011.

. Odisseia (em forma de narrativa). Trad. Jaime Bruna São Paulo: Cultrix, 2006.

HOWELLS, Coral Ann. "Five ways of looking at The Penelopiad". Disponível online:

http://escholarship.usyd.edu.au/journals/index.php/SSE/article/viewFile/590 1559. Último acesso: 24/09/2012.

INNES, Paul. Epic. The New Critical Idiom Series. Londres: Routledge, 2013.

JAEGER, Werner. Paideia: a formação do homem grego. Trad. Arthur Parreira. São Paulo: Marins Fontes, 2013.

JAUSS, Hans Robert. A história da literatura como provocação à teoria literária. Trad. Sérgio Tellaroli. São Paulo: Ática, 1994

JOHNSON, W. Ralph. Epic. In:: GRAFTON, Anthony et all (eds). The Classical Tradition. Cambridge: Harvard University Press, 2010. 
JOYCE, James. Ulisses. Trad. Caetano Galindo. Rio de Janeiro: Penguin/ Companhia das Letras, 2012.

KEARNS, Emily. The gods in homeric epics. In: FOWLER, Robert. The Cambridge Companion to Homer. London: Cambridge University Press, 2014, p.59-73.

KERMODE, Frank. The Classic: literary images of permanence and change. Cambridge: Harvard University Press, 1983, Reprint Edition.

KRAYE, Jimmy. "Rennaisance". In: GRAFTON, Anthony et all (eds). The Classical Tradition. Cambridge: Harvard University Press, 2010.

LEITE, Ana Mafalda. Modalização épica nas literaturas africanas. Lisboa, Vega, 1995.

LOURENÇO, Eduardo. "Uma viagem no coração do caos". In: Tavares, Gonçalo M. Uma viagem à Índia - Melancolia contemporânea (um itinerário). São Paulo: Leya, 2010, p.9-16.

LUKÁCS, Georg. A Teoria do Romance: um ensaio histórico-filosófico sobre as formas da grande épica. Trad. José Marcos Mariani de Macedo. Coleção Espírito Crítico. São Paulo: Duas Cidades; Ed. 34, 2000.

MACHADO, Ana Maria. Como e por que ler os clássicos universais desde cedo. Rio de Janeiro: Objetiva, 2009.

MADELÉNAT, Daniel. L’épopée. Paris: Presses Univesitaires de France, 1986.

MAFFEI, Luís. “Gonçalo Tavares, uma viagem ao valor com Camões ao fundo e alguns problemas contemporâneos". In: Via Atlântica. n 20. Niterói, dez 2011.

MAFRA, Johnny José. Cultura clássica grega e latina: temas fundadores da literatura ocidental. Belo Horizonte: PUC Minas, 2010.

MAGRIS, Claudio. "O romance é concebível sem o mundo moderno?" In: MORETTI, Franco (org.). O romance: a cultura do romance. Trad. Denise Bottman. São Paulo: Cosac Naify, 2009, pp.1015-1028. 
MANGUEL, Alberto. Ilíada e odisseia de Homero: uma biografia. Trad. Pedro Maia Soares. Rio de Janeiro: Jorge Zahar Editor, 2008.

MARQUES, Carlos Vaz. As palavras não se afogam ao atravessar o Atlântico. Rio de Janeiro: Tinta da China, 2015

MARTIN, René et Gaillard, Jacques. Les genres littéraires à Rome. Tome I. Paris: Scodel, 1981.

MCHALE, Brian. "From Modernist to Postmodernist Fiction" In: Postmodernist fiction. London: Methuen, 1987.

MILLER, Jane. Seductions: studies in Reading and culture. London: Virago, 1990.

MOHANTY, Chandra Talpade. Feminism without Borders: Decolonizing Theory, Practicing Solidarity. Durham \& London: Duke University Press, 2003.

MONTEIRO, George. "Camões's Os Lusíadas: the first modern epic". In: BATES, Catherine. The Cambridge Companion to the Epic. Cambridge: Cambridge University Press, 2010.

MONTEIRO, Mario Feijó Borges. Adaptações de clássicos literários para brasileiros. Dissertação de mestrado. Departamento de Letras. PUC-Rio, 2002.

MULVEY, Laura. "Visual pleasure and narrative cinema" In: Film Theory and Criticism: Introductory Readings. Eds. Leo Braudy and Marshall Cohen. New York: Oxford UP, 1999: 833-844.

NEIVA, Saulo. Epopée et modernité: caducité et réhabilitation d'um genre. Paris: Presses Univesitaires de France, 2014.

NUÑEZ, Carlinda. "A Dialética do clássico". In: CASTRO, Manuel Antônio de (org.). Dialética em questão I. Rio de Janeiro: Tempo Brasileiro, 2012. p. 93-112. 
OLIVEIRA, Ana Luisa. "A reabilitação da epopéia no século XX: o panamericanismo épico de Toda a América". In: Nau Literária. Porto Alegre. Vol. 04 n. 01 jan/jun, 2008.

PAZ, Olegário \& MONIZ, António. Dicionário breve de termos literários. Lisboa: Editorial Presença, 1997.

PALO, Maria José et all. Literatura Infantil: voz de criança. Série Princípios. São Paulo: Ática, 2006.

PEREIRA, Maria Helena da Rocha. Estudos de história da cultura clássica. Lisboa: Fundação Calouste Gulbenkian, 1987.

PINHO, Sebastião Tavares de. “A tradição do símile homérico e seu lugar na epopeia virgiliana” In: Humanitas. Vol XLVII . Coimbra, 1995.

PIÑON, Nélida. Aprendiz de Homero. Rio de Janeiro: Record, 2008.

PIQUEIRA, Gustavo. Odisseia de Homero (segundo João Vítor). São Paulo: Gaivota, 2013.

REAL, Miguel. "Viagem à Índia - do ser ao nada" In: Pluriel Revue des Cultures de Langue Portugaise. Disponível em: http://plural.espacoestudio.com/index.php?option=com_content\&view=artic le \&id=3013Aviagem-a-india-do-ser-ao-ada \&catid=55\%3Areste $\&$ Itemid=1 . Último acesso: 13/01/2017.

RENAUX, Sigrid. "Da Odisseia à Odisseia de Penélope": o coro de escravas como porta-voz da alteridade, violência e redenção". In: Revista Letras. Curitiba, n. 77, p.139-166, jan/abr. 2009.

RIBEIRO, João Ubaldo. Viva o povo brasileiro. Rio de Janeiro: Nova Fronteira, 2005.

RICH, Adrienne. "When we dead awaken: Writing as Re-Vision". College English, Vol. 34, No. 1, Women, Writing and Teaching (Oct., 1972), pp. 18-30 ". 
ROBERT. Marthe. Romance das origens, origens do romance. Trad. André Telles. São Paulo: Cosacnaify, 2008.

ROSENBLATT, Louise. "La teoria transacional de la lectura y escritura. In: Los processos de lectura y escritura. Buenos Aires: Lectura y Vida, 1996.

ROSSI, Aparecido. "O Senhor dos Anéis: o retorno da épica na pós-modernidade" In: Revista Iluminart do IFSP. Volume1, número 3. Sertãozinho: Setembro, 2009.

RUTHERFORD, Richard B. Classical literature: a concise history. Oxford: Blackwell Publishing. 2005.

SARAIVA, António. Luís de Camões. Lisboa: Gradiva, 1997.

SANT'ANNA, Afonso Romano. Paródia, paráfrase e cia. Série Princípios. São Paulo: 2006.

SETTIS, Salvatore. El futuro de lo clásico. Trad. Andrés Soria Olmedo. Madrid: ABADA Editores, 2006.

SILK, Michael. "The Odyssey and its explorations". In: The Cambridge Companion to Homer. Cambridge: Cambridge University Press, 2014, p.31-44.

SILVA, Anazildo Vasconcelos da; RAMALHO, Christina. História da Epopeia Brasileira. Rio de Janeiro, 2007, v.1.

SILVA, Victor Manuel de Aguiar e. Teoria da Literatura. Coimbra: Livraria Almedina, 1973.

SINHA, Sunita. Post-colonial Women Writers: New Perspectives. New York: Atlantic Publishers \& Dist, 2008.

SOARES, Angélica. Os Gêneros Literários. Série Princípios. São Paulo: Ática, 2006

STAIGER, Emil. Conceitos fundamentais da poética. Trad. Aída Galeão. Rio de Janeiro: Tempo Brasileiro, 1997. 
TAVARES, Gonçalo M. Uma viagem à Índia - melancolia contemporânea (um itinerário). São Paulo: Leya, 2010.

TEIXEIRA, Cláudia. "Uma guerra de sabor antigo: alguns elementos de inspiração homérica em Viva o povo brasileiro de João Ubaldo Ribeiro". In:

Boletim Estudos Clássicos, nº46. Coimbra, 2006.

TEIXEIRA, Ivan. Os Lusíadas: apresentação e notas. São Paulo: Ateliê Editorial, 2011.

TODOROV, Tzvetan. Crítica da crítica: um romance de aprendizagem. São Paulo: Unesp, 2015

VAN DER LINDEN, Sophie. Para ler o livro ilustrado. Trad. Dorotée de Bruchard. São Paulo: 2011.

VARGAS, Heron et all. "A colagem como processo criativo: da arte moderna ao motion graphics nos produtos midiáticos audiovisuais" In: Revista Comunicação Midiática, Vol. 6, No 3, set/dez 2011.

WATT, Ian. A Ascensão do Romance: estudos sobre Defoe, Richardson e Fielding. Trad. Hildegard Feist. São Paulo: Companhia das Letras, 2010.

WEBB, Timothy. "Homer and the Romantics" In: FOWLER, Robert. The Cambridge Companion to Homer. London: Cambridge University Press, 2014, p. 287-310. 
9

Anexos

Anexo 1

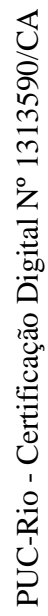

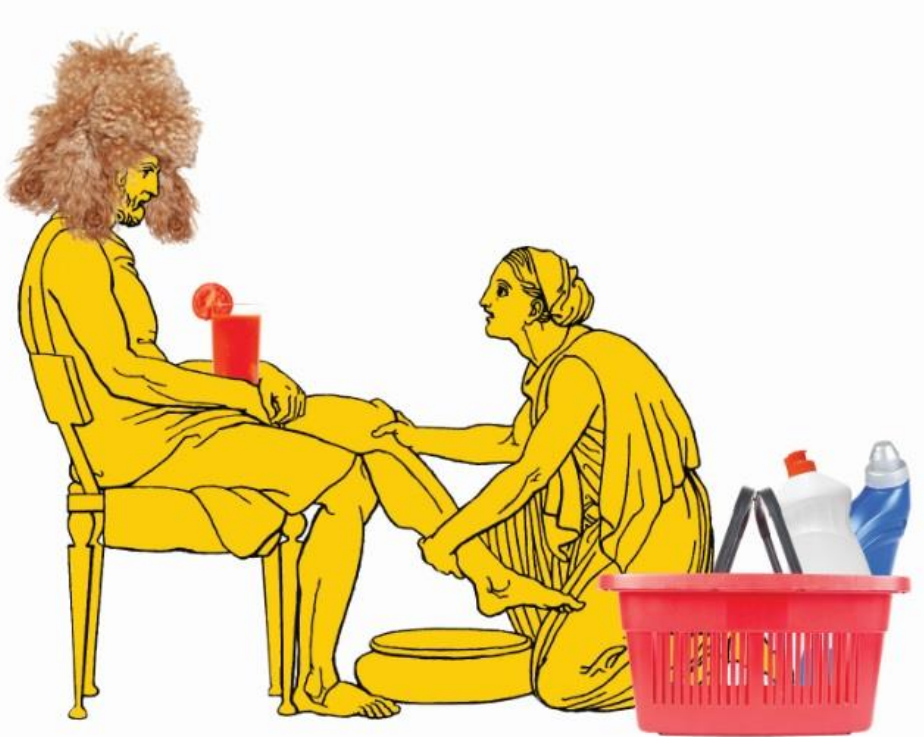

Anexo 2
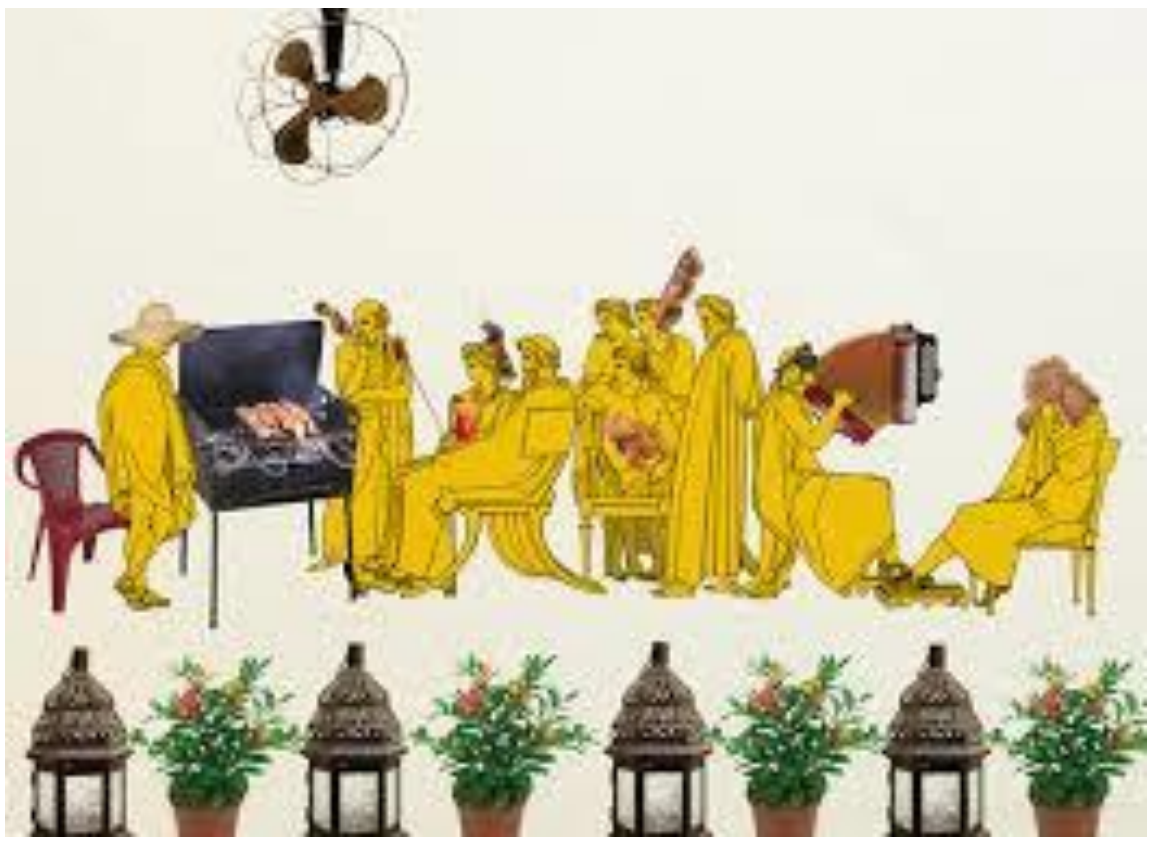


\section{Anexo 3}

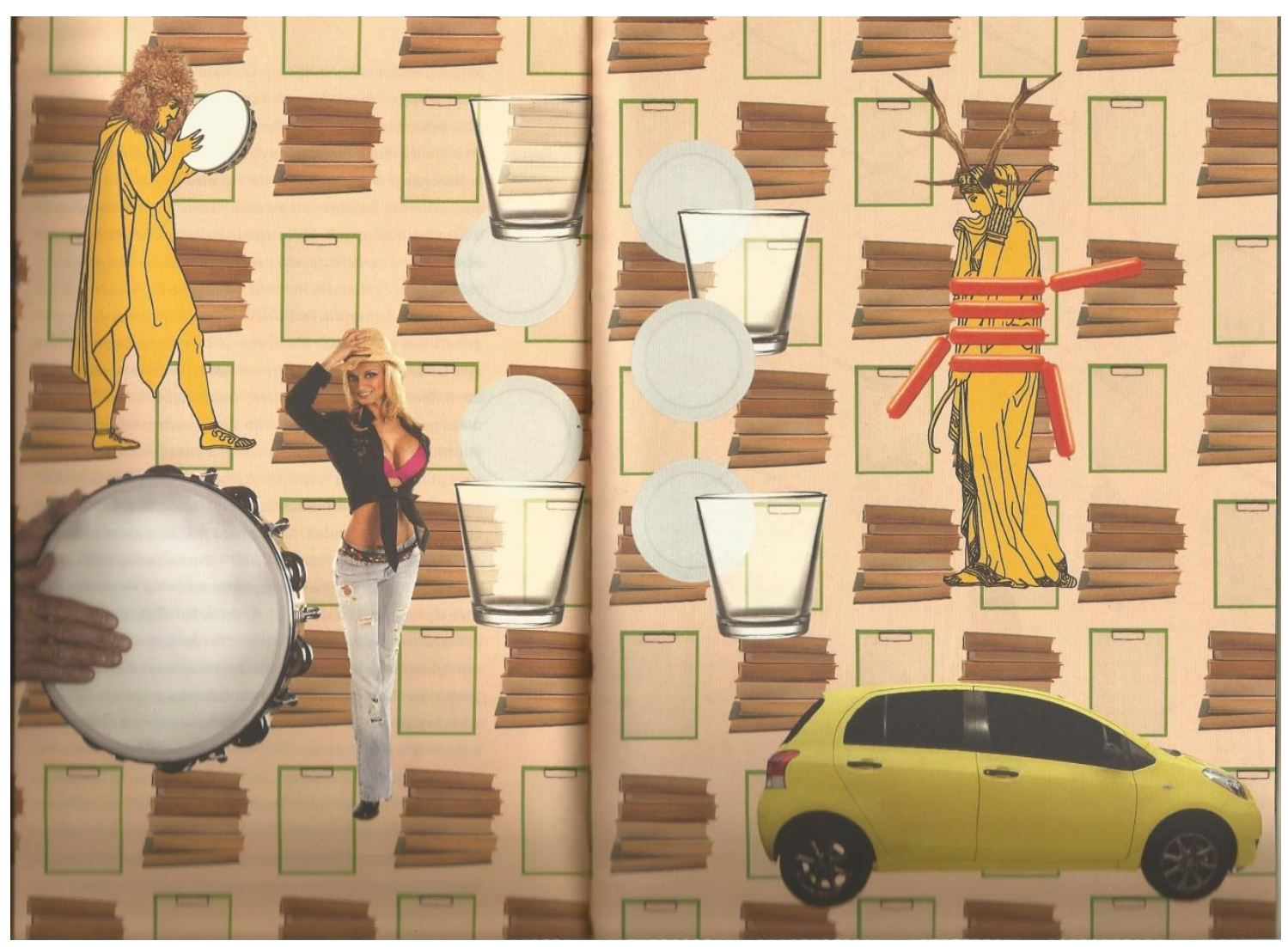

